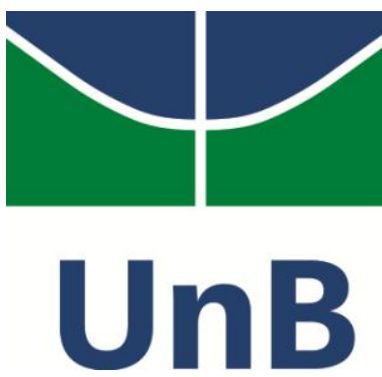

Instituto de Ciências Humanas

Programa de Pós-Graduação em História

\title{
"Dizem os irmãos": Propostas metodológicas de análise de um Compromisso de Irmandade Negra no período colonial
}

Linha de pesquisa: História Social e suas múltiplas formas

Mariana Fernandes Rodrigues Barreto Regis

Dissertação de Mestrado

Brasília

2016 


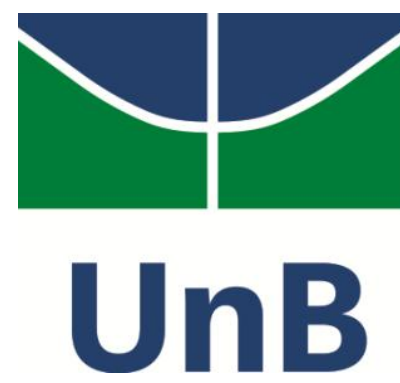

Instituto de Ciências Humanas

Programa de Pós-Graduação em História

\title{
"Dizem os irmãos": Propostas metodológicas de análise de um Compromisso de Irmandade Negra no período colonial
}

\author{
Dissertação de Mestrado apresentada ao \\ Programa de Pós-Graduação em História da \\ Universidade de Brasília como requisito parcial \\ para obtenção do título de Mestre em História. \\ Linha de pesquisa: História Social e suas \\ múltiplas formas.
}

Orientador: Prof. Dr. Tiago Luís Gil

Brasília

2016 
Mariana Fernandes Rodrigues Barreto Regis

\section{"Dizem os irmãos": Propostas metodológicas de análise de um Compromisso de Irmandade Negra no período colonial}

Dissertação de Mestrado apresentada ao

Programa de Pós-Graduação em História da

Universidade de Brasília como requisito parcial

para obtenção do título de Mestre em História.

Banca Examinadora:

Prof. Dr. Tiago Luís Gil (Orientador)

Prof. Dr. José Jorge de Carvalho (UnB)

Prof. Dr. Mauro Dillmann (FURG)

Suplente

Prof. Dr. Marcos Aurélio de Paula (UnB) 
"Há seis mil ano até pra plantar, os preto dança todo mundo igual sem errar, agradecendo aos céus pelas chuvas que caem, santo deus me fez Funk, obrigado meu pai."

Dexter e Mano Brown 
À Rosalina Rodrigues, (in memoriam), por ter me ensinado as mais valiosas lições desde pequena, entre elas o valor do estudo e de ter sido o melhor exemplo de mulher que eu poderia ter. 


\section{Agradecimentos}

À mainha, Doralina, a mulher mais forte que conheço e painho, Marcelo, o pai mais compreensivo, inteligente e amoroso que eu poderia ter. Obrigada por sempre terem me incentivado a estudar o que eu quisesse, por terem me auxiliado ao longo de toda vida com muito amor, carinho, conselhos, compreensão, dedicação, me apoiando financeiramente e por comemorarem comigo cada vitória nossa.

Ao meu orientador, Prof. Dr. Tiago Luís Gil, que lá nos primeiros semestres da graduação já acreditava no meu potencial como historiadora e sempre me mostrou o caminho a ser trilhado com muita sabedoria e paciência.

Aos professores Teresa Marques, Wanderson Flor do Nascimento, Haydeé Caruso e tantos outros que me ajudaram em diferentes momentos desta caminhada.

À toda minha família que sempre me apoio nas minhas decisões e se alegram com as minhas conquistas.

À família Foi Lossa, a minha irmandade e as Peneiradas, seletas, o melhor núcleo da novela.

À Janaína, por ser minha irmã e por estar presente todos os dias me fazendo ser uma pessoa melhor, à Maíra Guimarães, por toda a nossa amizade, carinho, incentivo, força, felicidade e por compartilhar tanta coisa comigo.

À Luisa Corrêa Leda e Tássia Vitória, por estarmos juntas nessa caminhada desde épocas das festas juninas da $1^{\text {a }}$ série e continuamos juntas.

À Vanessa Soares, Cecília Nóbrega e Letícia Alves, que foram minhas primeiras parceiras no curso de História e viraram minhas amigas pra toda a vida.

À Leila Saads e Lia Maria dos Santos, por terem sido além de amigas, minhas conselheiras acadêmicas ao longo de todo este processo. 
À Ana Rabêlo, minha antropóloga amada e venerada, que sabe apreciar uma boa sofrência, um axé e sempre me incentivou.

À Gabriela Moll e Melina Marques, por serem doninhas tão incríveis e amadas, presentes na minha vida.

À Árina Cynthia, Anna Bárbara, Amandinha, Beatriz (dog), Danielle (Daleste), Giovana, Lola, Lusa, Mila, Tataxa, Rayane (Tia Ray), as arrombs do meu coração.

Ao Dennis Novaes, Lucas Marques, Diego Simas, Diana Sobral, Victor Valentin, Luara De, Quércia, Geovana, Mila Fernandes, Uila Gabriela, Thânisia, Isabela Vitório, Ana Carolina (preta), Danilo Fleury, Tuti, Daniela Luciana, Khalil Santarém, Amílcar, Sérgio Magalhães e tantos outros grandes amigos que fiz durante essa caminhada! Desculpem não citar o nome de todos aqui.

Aos professores e alunos do IFCH - Unicamp, por me acolherem no segundo semestre do mestrado e ajudarem a enriquecer a minha formação acadêmica.

Ao bonde SP que depois de tantos anos longe, fizeram me sentir em casa, Hugo Cabral, Carlos Jr., Marina, Bárbara, Carol Ribeiro, Victão, Olívia e mais uma galera, que saudade de vocês.

À Tâmara, Tamine e Aníbal que sempre me deram aquela força, fazendo da casa de vocês, o meu pouso.

À todos pesquisadores do "Atlas Digital da América Lusa" desde sua primeira geração e em especial ao bonde do banquinho e todos os agregados.João Pedro, Manoel Rendeiro, Rasok (Carlos), Vinícius, Gabriela Sebba, João Vitor (Jovi), Pequi, Jéssica, Lana, Durval, a todos vocês, muito obrigada por todos os momentos de alegria, puxões de orelha, praia, trabalho, cerveja, comida boa, apoio e tudo mais que tão pouco tempo, já compartilhamos juntos.

Ao primeiro bonde do mestrado, Sarah, Fernanda, Daniel, Mariana Leo, Caio... muito sucesso pra nós! 
À Mariana Mesquita, por recentemente ter se tornado uma grande amiga e a melhor revisora que eu poderia ter, seu caminho é maravilhoso!

Á todos os amigos do curso de Graduação de História, aos amigos antigos e recentes, e a todos aqueles que acompanham minha caminhada, desculpem não citar o nome de todos.

Á todos os meus orixás, a seu Ventania e a dona Maria, por acompanharem meus passos.

Meus sinceros agradecimentos a todas e todos, não conseguiria chegar até aqui se não tivesse a ajuda de todos vocês. Ninguém caminha sozinho. Muito Axé. 


\section{Resumo}

Esta dissertação explora o compromisso de fundação da Irmandade da Nossa Senhora do Rosário dos homens pretos da Vila de Goiana, de 1783, procurando compreender o significado deste documento, como o mesmo reflete o contexto histórico vivido pelos irmãos e suas dinâmicas dentro da Irmandade. O trabalho se utiliza de várias propostas metodológicas para compreender de formas diversas o compromisso e consequentemente, os irmãos pretos de Goiana e suas dinâmicas sociais. Para a realização deste trabalho, as metodologias utilizadas foram a análise crítica, análise linguística, análise retórica e análise contextualista aplicadas ao compromisso.

Palavras-chave: Irmandades Negras. Religiosidade. Escravidão. Associações Religiosas. Metodologia da História. História social. América Lusa. 


\begin{abstract}
This dissertation explores the commitment of foundation of the Black Brotherhood of Our Lady of Rosario from the Vila of Goiana, 1783, seeking to comprehend how this document reflects the historical context lived by the brothers and the dynamics of the inside of the brotherhood. This work uses several methodologial approaches to understand in alternative ways the commitment and, therefore, the Black Brotherhood of Goiana and it's social dynamics. To accomplish this matter, the used methodologies were the critical analysis, linguistic analysis, rethorical analysis and contextualist analysis applied to the commitment.
\end{abstract}

Keywords: Black Brotherhoods. Religiosity. Slavery. Religious associations. Historical Methodology. Social History. Portuguese America. 


\section{Sumário}

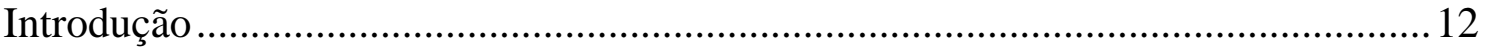

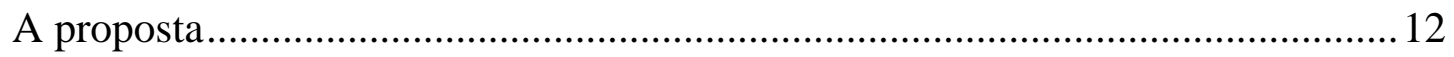

As irmandades no período colonial ................................................................. 16

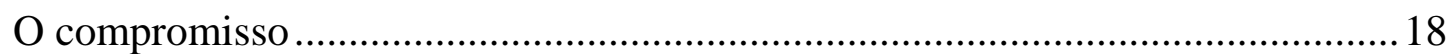

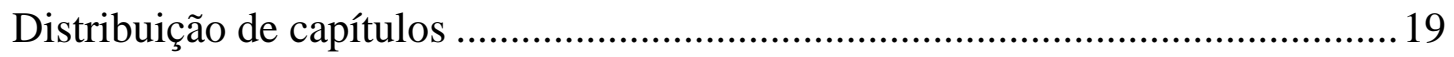

Capítulo 1 - O método crítico através do compromisso dos irmãos de Goiana ........21

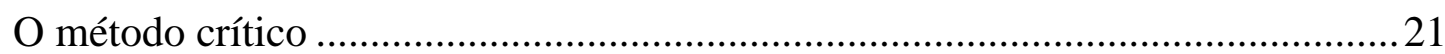

As irmandades através da análise crítica ......................................................... 28

Irmandade de Nossa Senhora do Rosário dos Pretos de Goiana ...........................2 29

Irmandade de Bom Jesus dos Martírios dos Pretos de Recife .............................. 37

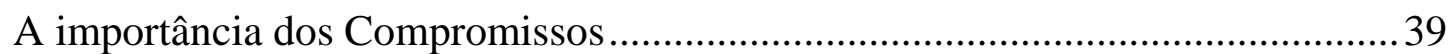

Capítulo 2 - Linguística e método histórico ........................................................... 41

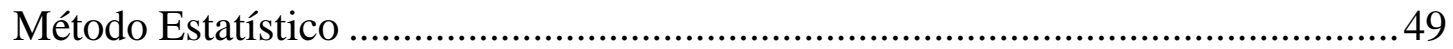

Abordagem dos Campos Semânticos ............................................................51

Capítulo 3 - A retórica utilizada para decifrar a leitura do Compromisso ................57

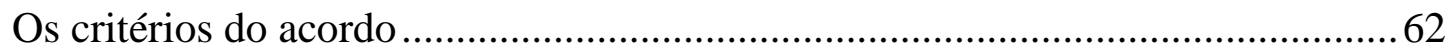

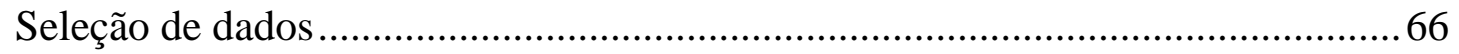

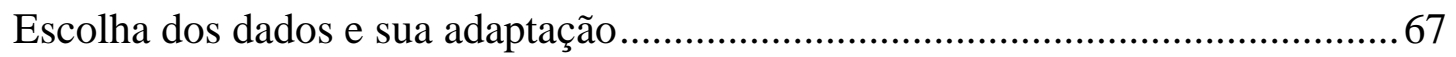

Análise retórica do Compromisso ........................................................................69

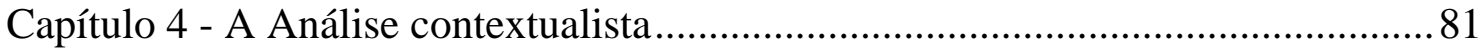

Análise contextualista do Compromisso ....................................................... 93

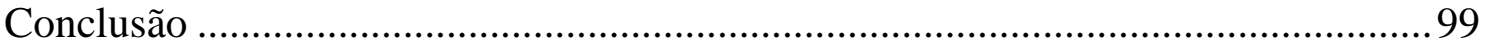

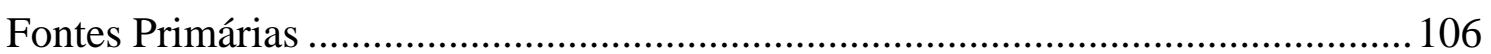

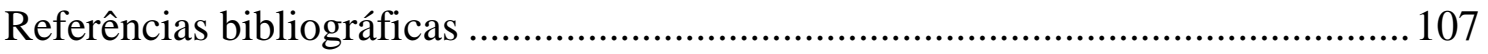

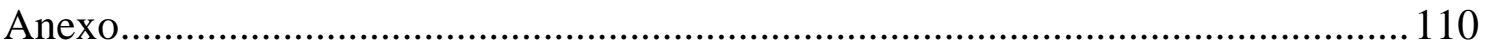




\section{Introdução}

\section{A proposta}

O objetivo deste trabalho é explorar o compromisso de fundação da Irmandade da Nossa Senhora do Rosário dos homens pretos da Vila de Goiana, fonte confeccionada por esta irmandade, para desta maneira compreender como este documento reflete o contexto histórico vividos pelos irmãos e suas dinâmicas na vila de Goiana. Esta obra se utiliza de diferentes propostas metodológicas para compreender de formas diversas o compromisso e consequentemente, os irmãos pretos de Goiana. As metodologias utilizadas para o trabalho são: análise crítica, análise linguística, análise retórica e análise contextualista.

A vila de Goiana, que atualmente se localiza como a cidade de Goiana, estado de Pernambuco, ao longo do século XVIII foi uma das vilas que ultrapassou a marca de 10 mil habitantes se tornando um local de importante ligação entre as vilas da região. ${ }^{1}$ Devido a importância da vila este trabalho delimitou seu foco de estudo na Irmandade da Nossa Senhora do Rosário dos pretos da vila de Goiana.

O início da ocupação da região não pode ser analisada por meio de registros em documentos oficiais, porém a autora Maria de Jesus Santa Silva nos explica que os primeiros engenhos da região começaram a ser instalados no século XVI. A partir da criação da paróquia de Goiana esta região da Zona da Mata do Norte de Pernambuco se tornou importante religiosamente, devido ao grande número de igrejas erguidas por associações leigas ao longo do período colonial. A Vila de Goiana se destacou desde a criação de seus primeiros engenhos, no século $\mathrm{XVI}^{2}$, devido ao seu grande desenvolvimento. O acesso a vila e a locomoção com engenhos vizinhos era facilitada devido as suas várzeas e rios que cortavam a região. A extração de pau-brasil trouxe um desenvolvimento econômico grande e o cultivo

\footnotetext{
${ }^{1}$ VASCONCELOS, Myziara Miranda da Silva. "Pela Vontade de Deus e bem dos Homens": o bem-morrer no documentos das Irmandades de pretos do Pernambuco colonial. Associação Nacional de História ANPUH - XXIV SIMPÓSIO NACIONAL DE HISTÓRIA - 2007. p.2

${ }^{2}$ A autora Maria de Jesus explica que não se sabe a data exata da fundação da paróquia de Goiana devido a falta de documentos, porém é provável que tenha sido fundada durante a visita pastoral de $D$. Frei Antonio Barreiros a Capitania de Itamaracá, em 1584.
} 
de açúcar fez com que cada vez mais fosse necessário a importação de escravos africanos para suas terras. ${ }^{3}$

O tráfico de pau-brasil foi um grande fator de desenvolvimento da região, além disso, os portos fluviais possibilitavam uma grande interação entre o Recife e as regiões das Capitanias do Norte, influenciando no comércio local. ${ }^{4}$

No período de dominação holandesa (1630-1654), Goiana teve seu crescimento estagnado, servindo de local para operações de invasão.Findado o período, Goiana retornou sua regularidade de crescimento. No ano de 1742 o local finalmente ganhava a denominação de Vila. ${ }^{5}$

Barbalho descreve como Goiana se tornou o centro economicamente mais importante da Capitania de Itamaracá.

\begin{abstract}
"Como se tratava de uma capitania donatarial, cujo donatário estava em Portugal, e que era governada por capitães-mores, os quais, muitas vezes, não tinham pulso para administrá-la, a Câmara Municipal como "cabeça da capitania" de Itamaracá, em várias ocasiões, tomava as resoluções das contendas, ou promovia levantes para atingir seus próprios interesses. Até 1685 , a única vila da capitania era Nossa Senhora da Conceição, sendo Goiana uma freguesia sob jurisdição daquela, mas quando Goiana tornouse vila, iniciou-se a disputa pela localização da Câmara, acarretando assim, a disputa pela sede da capitania. Ser "cabeça da capitania" dava privilégios maiores para a vila sede. Se a Câmara tinha jurisdição sobre o seu termo, a "cabeça da capitania" além de controlar seu termo, ainda podia fiscalizar os outros e a atuação das outras Câmaras Municipais."
\end{abstract}

Posteriormente, ao longo do século XVIII:

"No ano de 1746, contava a paróquia de Goiana 1.456 fogos, com 7.612 habitantes, a sua igreja matriz possuía 26 capelas filiais e, quanto à milícia da sua

\footnotetext{
${ }^{3}$ SILVA, Maria de Jesus Santana. Devoção e Resistência: As Irmandades de Homens Pretos de Goiana (1830-1850). Dissertação (Mestrado) - Universidade Católica de Pernambuco, Recife,2008.p.22 ${ }^{4}$ BARBALHO, Luciana de Carvalho. Capitania de Itamaracá poder local e conflito: Goiana e Nossa Senhora da Conceição. (1685-1742). Dissertação (Mestrado) - Universidade Federal da Paraíba, João Pessoa, 2009. p.73

${ }^{5}$ Idem. p.21

${ }^{6}$ Idem. p.76
} 
guarnição, havia 5 companhias de auxiliares, 4 de cavalaria, 1 de Henriques e 5 de ordenanças, com um efetivo de 977 praças. Nessa época, pertenciam ao distrito as freguesias de São Lourenço de Tejucupapo, desterro do També (depois Itambé), Itamaracá e Itaquara, que hora pertenca ao Estado da Paraíba.

Já em 1774, de acordo com os Anais da Biblioteca Nacional, Goiana possuía 14.506 habitantes. Sobre essa época, sabe-se que era considerada importante, possuía casa de Câmara, cadeia e pelourinho, convento do Carmo, seis igrejas, hospício e Casa de Misericórdia (Cf. Série Monografias Municipais, 1981, p.29). Contudo, somente no ano de 1785 , Goiana, definitivamente, foi elevada à categoria de Vila. $^{7}$

As irmandades católicas constituíram espaços importantes de devoção a fé católica e organização política e social por todo o território da América Lusa. No caso das irmandades compostas por africanos e seus descendentes além destas funções, elas representam um dos espaços onde se possibilitou a reconstrução cultural destes povos nas terras americanas.

Dentro destas confrarias, seus irmãos participavam de atividades relacionadas a devoção e gozavam de privilégios e auxílios. Como obrigação, sendo irmão de uma confraria católica, também era necessária colaboração em vários sentidos: financeiramente, assumindo obrigações com a igreja e suas atividades e seguindo a conduta da igreja a qual é filiado. Na América Portuguesa, as irmandades de pretos e seus descendentes constituíram instituições nas quais a população escrava e seus descendentes exerciam certa autonomia em relação a todo o sistema escravista colonial. Dentro destas confrarias foi possível a construção de identidades onde os desenraizados podiam viver e morrer solidariamente. Para os brancos este era um ambiente de dominação e domesticação, enquanto que os pretos encaravam este mesmo ambiente como um local de construção de identidade e solidariedade coletivas. $^{8}$

\footnotetext{
${ }^{7}$ Idem. p.21-22

${ }^{8}$ REIS, João José. Identidade e Diversidade Étnicas nas Irmandades Negras no Tempo da Escravidão. Tempo, Rio de Janeiro, vo.2, n³, 1996. p.4
} 
Este trabalho tinha como motivação inicial a exploração das fontes a respeito da Irmandade da Nossa Senhora do Rosário dos Homens Pretos da Vila de Goiana ao longo do século XVIII para assim compreender a organização social interna e como estes indivíduos se relacionavam externamente. Procurava-se assim enxergar o contexto político e social da região, além de procurar compreender as práticas religiosas destes indivíduos.

O primeiro empecilho apareceu quando se procurou trabalhar com vestígios dos africanos escravizados no período colonial. Quase não existem documentações do período produzidas pela população escrava ou seus descendentes. A documentação sobre o tema foi escrita por aqueles que detinham o poder social e econômico, na maioria das vezes, trazendo um relato que era uma representação da visão destes indivíduos a respeito dos povos escravizados, tornando um pouco mais complexa a procura por vestígios destes indivíduos e de suas práticas na documentação existe sobre o período. ${ }^{9}$ Deste modo, ao longo da pesquisa percebeuse a falta de fontes a respeito da Irmandade, já que a Irmandade só possui o compromisso de sua fundação como fonte durante o período analisado.

Com este impedimento, o foco do trabalho poderia ter sido modificado, aceitando que não haveria como estudar a irmandade no período histórico de sua fundação. Para continuar a trabalhar com a Irmandade do Rosário dos pretos de Goiana, a solução foi trabalhar apenas com o compromisso da irmandade, porém utilizando várias metodologias para a compreensão do período estudado.

Desta maneira, este trabalho explorou a fonte confeccionada pelo irmãos pretos de Goiana, o seu compromisso de fundação e assim, se utiliza de diferentes propostas metodológicas para compreender de formas diversas o documento histórico e consequentemente, analisar as práticas dos irmãos pretos de Goiana presentes no Compromisso. As metodologias utilizadas para o trabalho são: análise crítica, análise linguística, análise retórica e análise contextualista.

\footnotetext{
${ }^{9}$ REIS, João José. Tambores e Temores: a festa negra na Bahia na primeira metade do Século XIX. In: Carnavais e outras F(r)estas: ensaios de história social da cultura. Campinas: Editora da Unicamp, Cecult, 200. p.102
} 


\title{
As irmandades no período colonial
}

\begin{abstract}
"A riqueza maior do estudo das irmandades talvez seja no profundo significado histórico que elas apresentam. Foram e são instituições que se espelham e retratam os diversos momentos e contextos históricos nos quais se inserem. Com elas, o catolicismo e a Igreja Católica amoldam-se à realidade na qual se propagam. Nada de anacronismos históricos. As irmandades caracterizam sempre o seu momento e o seu ambiente, dando origem à diversidade de formas, por um lado, e à fluidez e imprecisão de suas denominações por outro."10
\end{abstract}

As irmandades católicas negras foram essenciais para a formação cultural, política e social do Brasil, na medida em que representaram um espaço de autonomia dentro da lógica do sistema colonial, enquanto que ao mesmo tempo, estavam submetidas aos dispositivos de controle da coroa portuguesa. Estas organizações fizeram com que os africanos e seus descendentes pudessem se inserir na religiosidade católica trazida do continente europeu pelos colonizadores. Tais ordens religiosas representaram um papel importante na disseminação das devoções adotadas pela população negra. ${ }^{11}$

Torna-se interessante situar que as irmandades de pretos cresceram em quantidade nas vilas e cidades ao longo de todo período colonial, porém, também existiam confrarias dentro das fazendas e engenhos mas que provavelmente, não alcançaram a influência que as irmandades urbanas adquiriram. ${ }^{12}$

A autora Mariza de Carvalho Soares, analisa a região urbana do Rio de Janeiro e afirma que o entusiasmo com o culto realizado pelos negros fez com que o número de irmandades crescesse muito na segunda metade do século XVIII. As procissões das irmandades eram seguidas por crescente número de adeptos, seguidas de conflitos que ocorriam entre as irmandades e o poder eclesiástico, ou originavam-se de disputas internas nas fraternidades. $\mathrm{Na}$

\footnotetext{
${ }^{10} \mathrm{BOSCH}$, Caio. Os Leigos e o Poder (Irmandades Leigas e Política Colonizadora em Minas Gerais). Editora Atica, 1986 .p.12

${ }^{11}$ REGINALDO, Lucilene. Os Rosários dos Angolas: Irmandades de Africanos e Crioulos na Bahia Setecentista. São Paulo: Alameda, 2011. p.134.

${ }^{12}$ REGINALDO. Op.Cit., p.144.
} 
organização destas irmandades, os princípios considerados fundamentais eram a origem da irmandade e a hierarquia a ser respeitada, tanto internamente, entre os membros da irmandades, quanto externamente, quando eram comparadas a outras irmandades e com as organizações eclesiásticas. De acordo com as prerrogativas de cada grupo, era possível definir a hierarquia das irmandades em vários momentos, como por exemplo, qual irmandade iria sair na frente nos dias de procissão. ${ }^{13}$

Nas Minas Gerais, Boschi explica que as irmandades foram um dos fatores responsáveis por manter laços sociais as vezes já preexistentes e em outros momentos, criados no próprio ambiente da irmandade, proporcionando o elo de identidade entre os seus membros, mesmo que estes fossem provenientes de diferentes regiões do continente africano ou nascidos na colônia. Todos sabiam que de alguma maneira, constituíam um grupo de relativa afinidade. Aprofundando o processo de construção identitária e fazendo perdurar a resistência das tradições africanas, essas confrarias também serviam como um espaço de desabafo das terríveis experiências vividas pela população cativa. Por todos esses motivos, as irmandades foram um dos poucos ambientes de sociabilização dos negros ao longo do período colonial. ${ }^{14}$

Na Bahia, Lucilene Reginaldo explica que entre pretos e pardos, haviam devotos de Nossa Senhora do Rosário desde o início do século XVII. Em nome desse culto, ergueram-se a capela das Portas do Carmo, juntamente com a Irmandade do Rosário dos pretos da Freguesia de São Pedro. Posteriormente, outras irmandades foram criadas. $^{15}$ A respeito da apropriação dos santos católicos, os santos negros assumiram para os africanos e seus descendentes, o lugar simbólico de ancestrais poderosos, em um grau de parentesco que a autora chama de "santo parente". ${ }^{16}$ Devido à configuração das irmandades negras na Bahia, surgiram mecanismos burocráticos informais, além de uma organização de poder paralela à eclesiástica. Desta maneira foi possível proporcionar

\footnotetext{
${ }^{13}$ SOARES, Mariza de Carvalho. Devotos da Cor. Rio de Janeiro: Civilização Brasileira, 2000, p.136

${ }^{14}$ BOSCHI. Op.Cit., p.152.

${ }^{15}$ REGINALDO. Op.Cit., p.125.

${ }^{16}$ REGINALDO. Op.Cit., p.140.
} 
condições para a reunião e resistência destas pessoas, conveniente para muitos propósitos, inclusive, articular levantes armados, e encobrir a fundação de um dos primeiros candomblés da Bahia, assim como fez a Irmandade do Senhor Bom Jesus dos Martírios da Igreja da Barroquinha. ${ }^{17}$

As tradições das Irmandades negras foram bastante preservadas em vários aspectos, desde de rituais sagrados realizados dentro de portas fechadas, apenas com os membros da confraria, até ações de cunho político das irmandades para o ambiente externo em que viviam. Dessa forma, o papel das irmandades de pretos do Rosário era mais do que religioso, revelava uma instituição de força política e auxílio entre seus membros. ${ }^{18}$

\section{O compromisso}

Compromissos de irmandades eram documentos que regulavam a organização e o funcionamento das irmandades e Confrarias por todo território colonial. As "Constituições Primeiras do Arcebispado da Bahia" do ano de 1707 trazem no seu livro quatro, título LX, a regulamentação dos compromissos:

"867 Por que as Confrarias devem ser instituídas para serviço de Deos nosso Senhor, honra, e veneração dos Santos, e se devem evitar nellas alguns abusos, e juramentos indiscretos, que os Confrades, ou Irmãos poem em seus Estatutos, ou Compromissos, obrigando com elles a pensões onerosas, e talvez indecentes, de que Deos nosso Senhor, e os Santos não são servidos, convém muito divertir estes inconvenientes. Por tanto mandamos, que das Confrarias deste nosso Arcebispado, que em sua creação forão erigir por autoridade nossa, ou daqui em diante se quizerem erigir com a mesma autoridade, que as faz Ecclesiasticas, se remettão a Nós os Estatutos, e Compromissos, que quizerem de novo fazer, ou já estiverem feitos, para se emendarem alguns abusos, se nelles os houver, e se passar licença in scriptis, para poderem usar delles.

868 E quanto ás Confrarias que forem erigidas sem autoridade nossa, e que são seculares, ordenamos, que os nossos Visitadores, nas Igrejas, em que estão fundadas, e em acto de Visita possão ver seus Estatutos, e Compromissos, para que tendo na sobredita forma alguns abusos, ou obrigações menos descentes, e pouco convenientes ao serviço de Deos, e dos Santos, as fação emendar, (dando-nos disso

\footnotetext{
${ }^{17}$ SILVEIRA. Renato da. O Candomblé da Barroquinha: processo de constituição do primeiro terreiro baiano de ketu. Salvador: Edições Maianga, 2006, p.150.

${ }^{18}$ REIS. Op.Cit, p.7
} 
conta, sendo necessario) ficando sempre as ditas Confrarias Seculares, como d'antes erão, sem que pela dita diligência possão os distos Visitadores e seus Officiaes levar salário algum.

869 E posto que da devoção, e piedade de nossos subditos podemos confiar, que sem esta nossa lembrança, a terão de instituirem em suas Igrejas, Confrarias, em que sirvão a Deos, e honrem a seus Santos; Nós com tudo que para mais os animar, lhes rogamos, e emcomendados muito, que tratem desta devoção das Confrarias, e de servirem, e venerarem nellas os Santos; principalmente á do Santíssimo Sacramento, e do Nome de JESUS, á Nossa Senhora, a das Almas do Purgatório, quanto for possivel, e a capacidade dos freguezes o permitir, porque estas Confrarias é bem as haja em todas as Igrejas." 19

O compromisso da Irmandade da Nossa Senhora dos Rosário dos pretos da Vila de Goiana é datado do ano de 1783 e trata sobre o regimento interno geral da irmandade a e como deveria ser seu funcionamento. O documento é organizado em quarenta capítulos,onde estão contidos: o compromisso com o pedido de confirmação da irmandade; o seu regimento interno, onde são explicadas detalhadamente as funções de cada irmão; os cargos existentes na Irmandade, as festas periódicas; os procedimentos em relação a morte dos irmãos ou seus parentes e quais os seus direitos e suas obrigações dentro da irmandade.

Tal documento nos mostra a importância da instituição na vida dos irmãos, seja na rigidez de seu regimento interno que indica desde quais cargos existirão na irmandade até a conduta de cada um deles. Assim sendo, o compromisso é a fonte para a realização deste trabalho, para desta maneira, analisar como tal documento pode ser trabalhado metodologicamente trazendo novas perspectivas para o estudo das Irmandades.

\section{Distribuição de capítulos}

O primeiro capítulo aborda a metodologia da análise crítica da História para compreender o compromisso dos irmãos de Goiana trazendo as condições de confecção da fonte e sua veracidade, analisando como o documento se relaciona

\footnotetext{
${ }^{19}$ Constituições Primeiras do Arcebispado da Bahia (1707), São Paulo, Tipografia Dois de Dezembro de Antônio Louzada Antunes, 1853. (In.: http://www2.senado.leg.br/bdsf/item/id/222291 ). p. 337
} 
com a Irmandade propriamente dita e quais os parâmetros necessários para que este documento fosse considerado legítimo ou não pela coroa portuguesa.

O segundo capítulo aborda a análise linguística do compromisso, versa sobre a linguística como ferramenta auxiliar dos estudos históricos. Para a análise do compromisso de Goiana foram utilizadas os método de análise do discurso contido no compromisso e análise estatística dos termos presentes na fonte e o que tais resultados podem trazer a respeito do contexto histórico estudado.

O terceiro capítulo aborda a análise retórica do compromisso, onde o documento é abordado pelo seu caráter argumentativo. Neste capítulo são analisadas como o compromisso se porta diante de seu auditório, que no caso, são as autoridades eclesiásticas e quais os artifícios utilizados para a argumentação e convencimento.

O quarto capítulo, traz a análise contextualista para a fonte histórica, procurando compreender como o compromisso dos irmãos pretos de Goiana se insere na conjuntura histórica, política e social do período analisado, no sentido de analisar as tradições e comportamentos que interferem no período de produção do compromisso. 


\section{Capítulo 1 - O método crítico através do compromisso dos irmãos de Goiana}

\section{O método crítico}

As fontes documentais são importantes vestígios do passado dos quais utilizamos para que a pesquisa histórica seja realizada, sendo assim, se faz necessário questionar as condições de produção das fontes utilizadas, qual a sua intenção e quais são as interpretações possíveis ao ler a fonte. Além disso, no trabalho do historiador também é preciso atentar para as relações sociais do período estudado, procurando compreender melhor o processo de criação do documento.

Ao se debruçarem sobre o seu objeto de análise, os historiadores devem levar em consideração, as condições de discurso nas quais o trabalho está submetido. Sobre o tema, Marc Bloch indica reflexões a respeito da prática historiográfica. Segundo o autor, é visível a evidência de que não se deve acreditar plenamente o que está descrito nos vestígios. Por um lado, estes vestígios podem ter sido escritos sob a influência de exigências externas trazendo para o documento uma série de informações e ocultando outras. Por outro lado, Bloch também nos diz muito sobre a falsificação de documentos. Estes, podem ter sido fabricados como algum tipo de cópia, o que também pode nos indicar intenções de quem o fez, quando existe a possibilidade de se comprovar a falsificação.Com a preocupação em relação a origem do documento, da fonte utilizada para a análise histórica, tornou-se necessária a crítica de bom senso, tornando a análise examinadora, buscando minuciosamente seus detalhes. ${ }^{20}$

A noção de "bom senso" não é o suficiente para analisar um texto ou uma experiência por exemplo, como verídica ou falsa, pois esse bom senso é um parâmetro escolhido através de critérios e experiências totalmente generalizados. Sendo assim, o real progresso no pensamento da análise crítica aconteceu quando a

\footnotetext{
${ }^{20} \mathrm{BLOCH}$, Marc. Apologia da história, ou, O ofício de Historiador. - Rio de Janeiro: Jorge Zahar Ed. 2001. p.90
} 
"dúvida" se tornou examinadora, questionadora dos paradigmas colocados em cheque pelo método crítico. ${ }^{21}$

Um dos grandes problemas causadores de análises parciais na História, ainda segundo Bloch, são os grandes modelos explicativos. Estes ensaios de interpretações que são utilizados como instrumentos metodológicos para se realizarem as análises históricas, muitas vezes são confrontados com documentos que trazem vestígios que não se encaixam. Os modelos explicativos apresentam uma proposta interessante para explicar a história, porém não se faz suficiente já que não cabem as diferentes especificidades que podem aparecer nas fontes e nas interpretações do historiador, sendo assim, estes blocos de interpretação não permitem as renovações de interpretação ou a elucidação de novos aspectos a respeito do objeto em questão.

\footnotetext{
"Para a História, o período de um tal cisma entre a preparação e a realização tem uma dupla face. [Atinge, primeira e cruelmente,] os grande ensaios de interpretação. Estes não faltam [não apenas, com isso,] ao dever primordial da veracidade [,pacientemente buscada]; privados, além disso, dessa perpétua renovação, dessa surpresa sempre renascente que luta com o documento é a única a proporcionar, torna-se-lhes impossível escapar a uma oscilação sem trégua entre alguns temas [estereotipados] impostos pela rotina. Mas o próprio trabalho técnico não sofre menos. Não sendo mais guiado de cima, arrisca-se a se agarrar indefinidamente a problemas insignificantes ou malformulados. Não existe pior desperdício do que o da erudição quando gira no vazio, nem soberba mais deslocada do que o orgulho do instrumento que se toma por um fim em si.,"22
}

A interpretação de acontecimentos passados transmitidos através de fontes primárias se apresenta de maneira mais complexa a cada vez que é revisitada. Em uma primeira análise, talvez as fontes podem ter sido interpretadas como relatos de fragmentos da realidade, porém partindo de uma análise crítica e com a frequência cada vez maior de revisitação dos documentos, fez-se necessário buscar por mais

\footnotetext{
${ }^{21}$ BLOCH, Marc. Apologia da história, ou, O ofício de Historiador. - Rio de Janeiro: Jorge Zahar Ed. 2001. p. 90

${ }^{22}$ Idem. p. 93.
} 
informações, procurando por aquelas que os próprios documentos não tinham a intenção de fornecer. ${ }^{23}$

Para enriquecer a análise histórica e verificar a veracidade dos documentos dos irmãos do Rosário, se faz necessário se debruçar em documentações produzidas no mesmo período e na região da capitania de Pernambuco e da Paraíba. Desta maneira, se faz necessário também o estudo de obras que abordam a mesma região.

Os autores Langlois e Sieghnobos no trazem no seu trabalho: "Introdução aos estudos históricos", uma série de procedimentos metodológicos a serem seguidos para que as fontes históricas sejam checadas como "verídicas" ou não, segundo os parâmetros colocados por tais autores.

Primeiramente, deve-se ter cuidado com perigo das cópias dos documentos originais. Os documentos originais dos séculos passados, geralmente estão em um ruim estado de conservação ou simplesmente estão tão deteriorados que não é mais possível realizar a leitura.

Além da deterioração realizada pelo tempo, ainda existe outro aspecto a respeito das cópias documentais:

\footnotetext{
"Cabe indagar, agora, em que estado os documentos antigos foram conservados. $\mathrm{Na}$ quase totalidade dos casos os originais estão perdidos; deles só existem cópias. Cópias extraídas diretamente do original? Não, mas cópias de cópias. Os escribas que as executaram não eram todos, como seria de se desejar, homens hábeis e conscienciosos; transcreviam com frequência textos que absolutamente não compreendiam, ou compreendiam mal, e não era de costume, como ao tempo da Renascença carolíngia, confrontar manuscritos." ${ }^{24}$
}

Devido a tais perigos alertados por Langlois e Seignobos, estes autores procuram maneiras de identificar se o texto analisado é um "bom ou mal” texto. O texto alerta para o fato de que é equivocado acreditar que grandes pesquisadores tinham acesso aos documentos em ótima condição e restaurados. Ao longo do

\footnotetext{
${ }^{23}$ Ibidem, p.96.

${ }^{24}$ LANGLOIS, Ch. V.; SEIGNOBOS, Ch. Introdução aos estudos históricos. Tradução Laerte de Almeida Morais. São Paulo: Renascença, 1946, p.51.
} 
tempo, historiadores e outros pesquisadores se atentaram para a qualidade em que o documento se encontra e como essa qualidade afeta o trabalho. Sendo assim, começaram a ser criados métodos para a apuração de documentos como fontes históricas, devido ao acúmulo de experiência que estes pesquisadores adquiriram. Para exemplificar a proposta dos autores, eles nos indicam que existem textos fáceis, que seriam os textos originais, esses portanto não são questionados a respeito da sua integridade. Outro exemplo de texto, seriam as cópias existentes, quando os originais se perderam, estes últimos, podem trazer uma série de questionamentos quanto a sua veracidade. ${ }^{25}$

A partir do momento em que os documentos originais se perderam, se faz necessário analisar as cópias de tais fontes, onde reside alguns problemas possíveis. As cópias de documentos podem ter sofrido alterações (na maioria das vezes sofrem) por conta do entendimento de quem a realizou, alterações que aconteceram inconscientemente, ou até mesmo propositalmente, trazendo uma análise errônea a respeito da fonte estudada.

\footnotetext{
"As alterações do original, em uma cópia, as "variantes de tradição", como se denominam, são imputáveis ou à fraude, ou ao erro. Certos copistas fizeram conscientemente modificações ou supressões. Quase todos os copistas cometeram erros, quer de julgamento, quer acidentais. Erros de julgamento quando, sendo semicultos e semi-inteligentes, abalançaram-se a corrigir passagens ou palavras do original, que não entendiam.

As modificações oriundas de fraudes, ou de erros de julgamento, são quase sempre mais difíceis de retificar e mesmo de descobrir. Certos erros acidentais (omissão de algumas linhas, por exemplo) são irreparáveis no caso, que nos ocupa, de uma cópia única."26
}

Essas modificações podem ser traduzidas em confusão de sentido, de palavras ou em erros de pontuação de frase, por exemplo, erros na tradução para outra língua que não seja a língua do documento original, podem trazer equívocos e confusões de tradução, equívocos de analogias e de pronúncia, sendo assim, faz-se

\footnotetext{
${ }^{25}$ Ibidem, p.53.

${ }^{26}$ LANGLOIS, Ch. V.; SEIGNOBOS, Ch. Introdução aos estudos históricos. Tradução Laerte de Almeida Morais. São Paulo: Renascença, 1946, p.54
} 
necessário o conhecimento aprofundado tanto na língua na qual o texto original está escrito, quando na língua para qual se pretende traduzir o texto. Também se faz necessário o conhecimento do modo de escrita do texto e o conhecimento prévio de variantes da tradição, ou seja, de confusões já citadas aqui anteriormente, como de sentido, ou de palavras. ${ }^{27}$

Ainda sobre as possíveis confusões que podem ser causadas pelas cópias interpretadas dos textos originais, é necessário deixar claro que os "maus" textos, aqueles que são falsificações ou cópias com trechos que não condizem com o original também são textos muito importantes para a análise histórica. Estes, tornam possíveis questionamentos a respeito dos motivos de sua falsificação, e suas consequências no período em que a falsificação foi realizada. ${ }^{28}$

Além das cópias falsificadas, Marc Bloch também dá atenção a outro tipo de relato do passado, o falso testemunho. O falso testemunho pode acontecer por uma série de motivos, como interesses pessoais por trás da mentira contada, circunstâncias em que a testemunha estava submetida, entre outras várias situações que não convém enumerar aqui, porém, sempre devemos estar atentos as condições em que os testemunhos foram coletados para compor a fonte em questão. ${ }^{29}$

De um lado está a escrita da cópia e do outro, se encontra a crítica, que julga se tal cópia produzida é um bom ou mal texto.

"De qualquer modo, numerosos textos conservados em forma corrupta e de eu só uma cópia existe, continuam resistindo e resistirão sempre a todo esforço crítico.

Frequentemente a crítica verifica a alteração do texto e sugere o que o sentido reclama, mas, se é prudente, deve contentar-se com isso, pois, estando apagados os traços da primitiva forma por verdadeira multidão de erros e correções sucessivas não há como destrinçar a meada.

\footnotetext{
${ }^{27}$ Idem.

${ }^{28}$ BLOCH, Marc. Apologia da história, ou, O ofício de Historiador. - Rio de Janeiro: Jorge Zahar Ed. 2001.p.98

${ }^{29}$ Idem. p. 105
} 
Os eruditos que se entregam ao exercício apaixonante da crítica conjectural estão expostos, em seu ardor, a suspeitar de hipóteses temerárias." ${ }^{30}$

A crítica sobre a veracidade do texto analisado, e escolhido como fonte para um trabalho histórico, deve ser realizada para que assim, possam ser minimizados os equívocos de interpretação das fontes ou o mal uso delas.

Além destes aspectos, existem outros aspectos das fontes históricas, que também devem ser analisados com bastante rigor. Assim, se faz importante analisar a procedência do texto em questão. ${ }^{31}$ Para a análise da procedência, faz-se necessário primeiro, se despir de algumas regras supostas pelos historiadores que trazem a ideia de legitimidade do texto. Segundo os autores, alguns questionamentos básicos já dão uma noção de procedência como:

\footnotetext{
"Em presença de um documento é preciso, pois, indagar:

De onde proveio ele? Qual o seu autor? A que época pertence?" Um documento cujo autor, data, lugar de origem, em suma, cuja procedência é totalmente desconhecida, de nada serve. ${ }^{32}$

"A análise interna do documento, desde que haja sido feita cuidadosamente, nos dá, em geral, noções suficientes, relativamente à sua procedência. A comparação metódica entre os correspondentes dos documentos similares, cuja procedência é certa, permitiu desmascarar grande número de falsários e precisar as circunstâncias em que a maioria dos documentos sinceros foi produzida. ${ }^{33}$
}

Porém, além destes primeiros questionamentos, deve-se notar que que não devemos confiar plenamente nas respostas obtidas por eles, já que é documentos podem ser, simplesmente, falsificados, modificados ao longo do tempo. Para que se possa acreditar de maneira mais confiável em um documento, segundo Langlois e Seignobos, é necessária a "análise interna" 34 , observando a forma de escrita do

\footnotetext{
${ }^{30}$ LANGLOIS, Ch. V.; SEIGNOBOS, Ch. Introdução aos estudos históricos. Tradução Laerte de Almeida Morais. São Paulo: Renascença, 1946, p.56.

${ }^{31}$ Idem, p.62.

${ }^{32}$ Ibidem.

${ }^{33}$ Ibidem, p.65.

${ }^{34}$ LANGLOIS, Ch. V.; SEIGNOBOS, Ch. Introdução aos estudos históricos. Tradução Laerte de Almeida Morais. São Paulo: Renascença, 1946, p.63. "análise interna" do documento" onde deverá ser fixada
} 
documento, pois algumas formas específicas de escrita só foram realizadas em períodos históricos específicos, em localidades particulares. ${ }^{35}$ Após a varredura no interior do documento, o olhar se volta para o que está ao seu redor, externamente. A fonte deve agora, ser confrontada com outras fontes, pois a comparação entre documentos produzidos em um mesmo período histórico e na mesma região, pode ajudar bastante a eliminar aquilo que não possui coerência com a tradição, o que não faz sentido. Também se faz necessária a procura de documentos que abordem a obra analisada, que fazem referência, ou tenham sido inspiradas por tal fonte. ${ }^{36}$

Ainda sobre a crítica da procedência, Langlois e Seignobos, falam sobre a importância das fontes em que os autores dos documentos estudados se serviram, estas também revelam uma série de nuances sobre o resultado do texto final. Os documentos afins, devem ser organizados como uma árvore genealógica, onde possam fazer sentido entre si, construindo assim uma relação mais sólida com o contexto em que foi produzido. ${ }^{37}$

Finalizando a crítica da procedência, é interessante tomar cuidado com a desconfiança excessiva do documento, podendo perder uma série de análises possíveis a partir do "bons" e também, a partir dos "maus" documentos.

"É, pois, louvável reagir contra os que nunca duvidam da procedência dos documentos; mas é avançar muito tomar interesse exclusivamente, como reação, pelos períodos da história cujos documentos são de procedência incerta. Os documentos da história moderna e contemporânea são tão dignos de interesse quanto os da antiguidade ou da idademédia porque sua procedência aparente, embora seja quase sempre verdadeira, não exclui delicados problemas de atribuição nem se furta aos preceitos da crítica.

É preciso que com ela não nos contenhamos, porque a crítica de procedência, como a de restauração é preparatória, e seus resultados são negativos. O seu objetivo último é eliminar os documentos imprestáveis, que só serviriam para confundir a levar ao erro; eis tudo."

todas as informações que não trazem esclarecimentos suficientes sobre o documento estudado e sobre o autor, ou os autores do documento.

${ }^{35}$ Ibidem, p.64.

${ }^{36}$ Ibidem, p.65

${ }^{37}$ Ibidem, p.68. 


\section{As irmandades através da análise crítica}

No estudo específico das irmandades negras na América Portuguesa, esbarramos em mais alguns problemas metodológicos, quando são tratados temas a respeito dos povos escravizados e seus descendentes. Estes, na maioria das vezes, quase não produziram fontes documentais escritas por eles mesmos, por isso, o que conseguimos estudar sobre os africanos e seus descendentes são documentações através das fontes oficiais, redigidas pelas autoridades eclesiásticas, civis, relatos de viajantes e pela elite colonial, como nos explica João José Reis:

"Por dispormos de pouca documentação da época quase nada - escrita por negros ou traduzindo diretamente sua visão de mundo, é muito difícil saber como eles percebiam e significavam o que se passava em suas festas. É certo que, através das ações narradas nos documentos disponíveis, sabemos da insistência dos negros em fazer um mundo seu do lugar e da hora de festejar, um mundo que desejavam sempre mais ampliado em tempo, espaço, formas, gestos, jeitos, com abundância de dança, música, comida, bebida, dádivas e deuses. E para alcançarem este objetivo, precisaram negociar concessões ou desafiar a soberba dos detentores de pequenos e grandes poderes.

É mais fácil saber o que se passava na cabeça dos que detinham o poder de denunciar, reprimir ou permitir. A história da festa negra em geral nos chega pela pena dos que a toleravam, criticavam ou perseguiam, dos policiais, religiosos, jornalistas, governantes." 38

A respeito das Irmandades negras, o estudo esbarre em um problema parecido. Estas confrarias originalmente de brancos, se disseminaram ao longo do território da diáspora como um lugar de devoção e no caso dos africanos e seus descendentes, era um indício da catequização realizada com estes povos. ${ }^{39}$

As irmandades de pretos da América Portuguesa eram semelhantes entre si quando falamos sobre as suas formas de organização, sendo assim, os documentos

\footnotetext{
${ }^{38}$ REIS, João José. Tambores e Temores: a festa negra na Bahia na primeira metade do Século XIX. In: Carnavais e outras F(r)estas: ensaios de história social da cultura. Campinas: Editora da Unicamp, Cecult, 2002. p.102

${ }^{39}$ BEZERRA, Janaína Santos. Pardos na cor \& Impuros no Sangue: etnia, sociabilidades e lutas por inclusão social no espaço urbano pernambucano do XVIII.

-UFRPE - Recife, 2010. p.81
} 
provenientes destas irmandades também seguem uma regularidade e através de sua análise é possível encontrar traços importantes a respeito do modo de vida dessas pessoas e das semelhanças e singularidades entre as irmandades católicas. As similaridades entre os documentos das irmandades do período colonial existem por conta das semelhanças entre as organizações das confrarias, mas também por conta das exigências pelas quais as irmandades tinham que se adequar, quando submetiam sua documentação a aprovação do reino. ${ }^{40}$

\section{Irmandade de Nossa Senhora do Rosário dos Pretos de Goiana}

Ao trazer a análise crítica da história para dentro do compromisso de fundação da Irmandade da Nossa Senhora do Rosário dos Pretos de Goiana, podemos atentar para uma série de detalhes. Para que seja possível analisar o compromisso através de um olhar crítico deve-se atentar para detalhes sobre a confecção da obra em questão.

Sendo assim, o compromisso da Irmandade da Nossa Senhora do Rosário dos Irmãos Pretos de Goiana é um documento produzido no ano de 1783, na vila de Goiana, integrante da Capitania da Paraíba do Norte e importante local de passagem para quem ia para a cidade do Recife. O compromisso dos irmãos de Goiana traz o regulamento de assuntos referentes a irmandade, como os cargos, as festas, as obrigações e direitos dos irmãos e como a confraria funcionava.

Os irmãos do Rosário de Goiana, assim como tantas outras irmandades de africanos e seus descendentes, se idealizaram e foram criadas a partir dos referenciais das irmandades católicas de brancos, já instaladas amplamente ao longo do território da colônia, na segunda metade do século XVIII. Sendo assim, segundo os princípios analisados anteriormente a respeito da análise crítica, é pertinente analisar o compromisso da Irmandade dos pretos de Goiana, com outros compromissos.

\footnotetext{
${ }^{40}$ VASCONCELOS, Myziara Miranda da Silva. "Pela Vontade de Deus e bem dos Homens": o bemmorrer no documentos das Irmandades de pretos do Pernambuco colonial. Associação Nacional de História - ANPUH - XXIV SIMPÓSIO NACIONAL DE HISTÓRIA - 2007. p.2
} 
No estudo de Maria da Vitória Barbosa Lima, sobre os escravos e libertos na Paraíba escravista, assim como na maioria das Irmandades de pretos do Brasil Colonial as características se assemelham a Irmandade de pretos de Goiana:

“A memória cristã revelada pelas irmandades negras cristalizou-se, sobretudo, no culto aos santos e aos mortos. As festas dos oragos e os cortejos fúnebres eram importantes para a comunidade negra porque eram momentos de se expor e, sobretudo, porque se revelava o prestígio da entidade. Em ambos, a pompa fazia parte da tradição cerimonial, por serem festas faces públicas das irmandades. A preparação da festa ocorria no período entre quinze dias a dois meses antes da sua culminância e era mantida pelas esmolas doadas aos irmãos." 41

Desta maneira, o relato a partir destas fontes, ou seja, compromissos de irmandade, consegue nos trazer vestígios a respeito do modo de vida dos africanos e descendentes, das autoridades que detinham o poder colonial e também explica bastante sobre a dinâmica social entre esses diferentes grupos que conviviam na Vila de Goiana, na capitania da Paraíba do Norte e nas capitanias vizinhas. É necessário que análise histórica seja realizada atentando para esses detalhes que permeiam as fontes do período colonial que abordam a escravidão.

O uso de compromissos de irmandades católicas são documentos riquíssimos para a análise historiográfica pois partindo desta documentação, é possível enxergar um pouco sobre a visão dos irmãos e também o que era exigido pelas autoridades eclesiásticas, como nos explica a autora Janaína Santos Bezerra:

“[...] a relevância dos compromissos como fonte para esta análise pode ser considerada, por um lado, por terem sido utilizados como instrumento de controle social e de garantia de manutenção do próprio sistema colonial, por outro, pela sua característica de corpo normatizador que organizava e sintetizava as relações intragremiais dos indivíduos. Porém, é importante destacar que os compromissos não revelavam todas as atividades das irmandades envolvidas em muitos segredos e silêncios. O auxílio dado aos irmãos mais necessitados, a ajuda aos doentes, o alimento que se levava ao preso, raramente são mencionados nos capítulos dos compromissos. Assim, a nossa preocupação se volta não apenas para a normatização

\footnotetext{
${ }^{41}$ LIMA, Maria da Vitória Barbosa. Liberdade Interditada, Liberdade Reavida: escravos e libertos na Paraíba escravista (século XIX) - Brasília: FCP, 2013, p.91.
} 
contida nesses estatutos, mas também as relações sociais que lhe são inerentes." 42

O compromisso da Irmandade da Nossa Senhora do Rosário dos pretos da Villa de Goiana foi escrito no ano de 1783 e traz basicamente, um regimento interno geral a respeito de seu funcionamento. $\mathrm{O}$ documento foi redigido e organizado em quarenta capítulos, onde estão contidos o compromisso com o pedido de confirmação da irmandade e o seu regimento interno, onde são explicadas detalhadamente as funções de cada irmão, os cargos existentes na Irmandade e quais os seus direitos e suas obrigações dentro da irmandade.

O compromisso da irmandade é um documento constituído por uma série de tópicos que constituem os termos considerados essenciais que deveriam constar nos compromissos das irmandades do século XVIII, para que esta fosse considerada autorizada a funcionar. Assim, outras informações que seriam muito importantes para o estudo acerca das Irmandades do período não estão nos documentos como por exemplo, os rituais a serem realizados, as orações e demais práticas realizadas pelos irmãos pretos do Rosário de Goiana.

Para tornar possível a análise crítica do compromisso da Irmandade de Nossa Senhora do Rosário dos Pretos de Goiana, de acordo com os critérios expostos acima, escolhi comparar o documento ao compromisso da Irmandade do Senhor Bom Jesus dos Martírios dos Homens Pretos da Vila de Recife, redigido em 1787.

A comparação da irmandade de Goiana com a de Recife se faz pertinente devido à proximidade geográfica das duas vilas,ao período histórico analisado e ao fato de que a duas irmandades se assemelhavam por serem irmandades de pretos.

Como já foi citado neste capítulo, as irmandades da América Portuguesa precisavam do compromisso para estarem aptas a funcionar de acordo com a lei, e para isso, a maioria dos compromissos seguem um fio condutor na sua descrição sobre a irmandade para conseguir o aval das autoridades, portanto, é de se esperar

\footnotetext{
${ }^{42}$ BEZERRA, Janaína Santos. Pardos na cor \& Impuros no Sangue: etnia, sociabilidades e lutas por inclusão social no espaço urbano pernambucano do XVIII. -UFRPE - Recife, 2010, p.84.
} 
que as duas irmandades tenham compromissos com organizações bastante parecidas. É isso que vai ser comparado a seguir.

O primeiro capítulo do compromisso dos irmãos do Rosário dos pretos de Goiana, nos explica sobre as pessoas que seriam aceitas na irmandade, onde o prérequisito mais importante para a aceitação, era o conhecimento da fé cristã e a devoção a Nossa Senhora do Rosário, além do cumprimento das ordens descritas no regimento. Porém, é explicitado no capítulo que poderiam fazer parte da irmandade, brancos, pardos, pretos do Reino de Angola e da costa da Guiné, contando que possuam o conhecimento sobre a fé cristã.

São definidos os cargos da Irmandade no quarto capítulo, estes seriam eleitos através do voto e valeriam por um ano, entre eles estão um Juiz de Mesa, um escrivão, um procurador, um tesoureiro, doze mordomos (sendo que seis deveriam ser obrigatoriamente naturais do Brasil e seis do gentio de Angola). Um dos requisitos mais importantes para ocupar tais cargos era ser devoto da fé cristã e se dedicar as atividades da Irmandade. Ainda no primeiro capítulo, é explicado que caso o irmão seja zeloso e esteja com alguma obra em andamento, seu período no cargo pode ser estendido até o final da obra em andamento mesmo que ultrapasse um ano no posto. O capítulo seguinte fala sobre a eleição do capelão da Irmandade, onde o eleito, deveria ser aquele dos sacerdotes que exercesse " mais santa vida com a perfeição de Pregador e Confessor prudente para exemplar e educar a irmandade". Adiante seguem os tributos que devem ser pagos de acordo com o cargo do irmão, entre estes estão, os juízes, os reis e rainhas de congo e os demais cargos.

\section{Procissão, festejos e Coroação do Rei e Rainha do Congo}

Nos capítulos seguintes, se regulamenta a festividade da Irmandade, em quais dias a procissão deverá acontecer, em quais condições e como deverão prosseguir caso não haja a possibilidade de haver a festa, assim como devem se comportar no dia da procissão. Neste ponto são descritos inclusive o posicionamento em que os irmãos devem se colocar. As funções do tesoureiro, escrivão, sacristão, dos irmãos 
da mesa e dos demais irmãos são descritas nos capítulos seguintes, onde se percebe uma rigidez no cumprimento das obrigações da irmandade, sendo os irmãos penalizados caso não cumpram ou caso tenham um desempenho ruim.

Além da procissão dedicada a Nossa Senhora do Rosário dos pretos, a Irmandade também realizava como festividade, a coroação do Rei e da Rainha do Congo. No compromisso, é explicado que no dia da coroação, todos os irmãos presentes tinham como obrigação o pagamento de dez tostões pela missa e pelo ritual de coroação, sendo que a quantia que sobrasse, deveria ser revertida para obras na sacristia.

A existência da coroação de rei e rainha na Irmandade do Rosário dos pretos de Goiana nos revela bastante sobre a interação da população africana e de seus descendentes na diáspora americana. ${ }^{43}$ Essa coroação pode nos mostrar traços de uma construção de novos processos de construção de identidades, necessário para a reorganização dos povos escravizados na diáspora. Sobre a coroação dos reis e rainhas do Congo, Marina de Mello e Souza esclarece que:

\begin{abstract}
"Assim, considerando os reinados negros como manifestações culturais com significados distintos para aquele que os realizavam, ou seja as comunidades negras, e para aqueles que tinham o controle da sociedade escravista, para uns eles seriam formas de organização social e de construção de novas identidades, e para outros seriam comprovação do domínio sobre a comunidade negras e de um poder articulado ao império. Dessa forma, a unificação dos diversos reis de nação em uma única designação, de rei do Congo, liga-se, no meu entender, a esses dois universos culturais, o dos negros e o dos brancos. De um lado houve a consolidação de uma identidade mais uniforme adotada por africanos de origens diferentes, que passaram a se ver como membros de uma comunidade católica negra, parte da sociedade brasileira para a qual eles ou seus antepassados foram trazidos. De outro lado, o lugar de destaque que o reino do Congo ocupava no imaginário lusitano, principal matriz das maneiras de pensar da classe senhorial brasileira e que permaneceu presente mesmo quando o Brasil se tornou independente de Portugal, ajudou a aceitação das congadas
\end{abstract}

\footnotetext{
${ }^{43}$ MELLO E SOUZA, Marina de. Catolicismo Negro no Brasil: Santos e minkisi, uma reflexão sobre miscigenação cultural. Afro-Ásia, número 28, 2002, pp. 125-146, UFBA - Brasil. Disponível em: http://www.redalyc.org/articulo.oa?id=77002805, p.127.
} 
por meio e por meio delas a integração de alguns grupos de descendentes de africanos à sociedade brasileira."

No trabalho de Maristela Simão, autora trabalha com outros compromissos do bispado de Pernambuco e percebe que, assim como nos irmãos do Rosário dos pretos de Goiana, nas outras irmandades, todos poderiam se associar, sendo que o crivo era realizado por exclusão, onde alguns grupos específicos não poderiam participar da irmandade, além disso, as irmandades do Rosário tinham como exigência, subdivisões especificas a respeito das "nações" específicas dos pretos. ${ }^{45}$

\section{O "morrer" entre os Irmãos}

O compromisso nos mostra a importância da instituição na vida dos irmãos, seja na rigidez de seu regimento interno que indica desde quais cargos existirão na irmandade até a conduta de cada um deles, tal importância também é exposta quando o documento trata sobre a morte dos irmãos. Parece que além da festa que acontece na procissão anual de Nossa Senhora do Rosário, outra função importante da irmandade é o sepultamento dos irmãos e todas as atividades que envolvem os seus rituais de morte. Assim como descrito no capítulo XXII, que aborda a disposição das sepulturas e como os irmãos devem ser enterrados de acordo com seu cargo, no capítulo XXV é tratada a disposição da tumba durante o carreto e no capítulo XXIX, sobre como reger as procissões e enterros. Outros capítulos, como o II, III e IV, falam sobre os procedimentos a serem seguidos caso haja o falecimento de irmãos ou de seus familiares e quais seus direitos.

No capítulo XXII é descrito minuciosamente como devem ser enterrados os irmãos: "Nas primeiras covas abaixo do arco da Capela Mor só se enterrarão os Juizes, e Ex-Juizes, Juizas e Ex-Juizas no segundo andar das ditas sepulturas, os Escrivãos, e Ex-escrivãos, escrivaas e ex-escrivaas no terceiro andar, os procuradoes, ex-procuradores no quarto andar os irmãos da Meza, destes se entende

\footnotetext{
${ }^{44}$ MELLO E SOUZA, Marina de. Reis do Congo no Brasil, séculos XVIII e XIX. Revista de História, núm. 152, junho, 2005, pp 79-98. USP - São Paulo, Brasil.Disponível em: http://www.redalyc.org/articulo.oa?id $=285022040004$

${ }^{45}$ SIMÃO, Maristela dos Santos. As irmandades da Nossa Senhora do Rosário e os Africanos no Brasil do Século XVIII. Faculdade de Letras, Universidade de Lisboa, 2010. p.80
} 
falecendo no anno em que servirem, que fora delle serão sepultados na Sacristia.”. Os outros irmãos, não ocupantes de tais cargos, não poderiam ser enterrados em sepulturas com letreiros particulares, a não ser que pagassem pelo sepultamento uma quantia que fosse estipulada pelo juiz da mesa. Também é importante ressaltar que as esposas dos irmãos, caso viessem a falecer, recebiam o mesmo tratamento do seu marido, sendo sepultada de acordo com o cargo que o irmão ocupava na irmandade. Ainda sobre os enterros, era proibido o carregamento da tumba de pessoas não integrantes da irmandade, ao se pagar sete mil réis de esmola, teriam direito somente a um esquife e um pano, pois segundo o compromisso, os direitos do carregamento da tumba era somente para irmãos e irmãs.

Além da preocupação com o sepultamento dos irmãos, a irmandade também prestava assistência ao irmão caso sua esposa visse a falecer e vice-e-versa, sendo que no caso do irmão falecer, a esposa que arcasse com os tributos as anuidades da Irmandade gozava dos direitos de seu marido dentro da confraria. O mesmo acontecia com os filhos que perdiam os pais, se estes fossem casados, o filho ou filhaa partir dos doze anos, também recebia os direitos dos pais.

Eram celebradas missas, tanto para os irmãos vivos quanto para os irmãos mortos, sendo aos domingos as dos irmãos vivos, e nos outros dias santos a dos irmãos mortos. Em outros momentos, era necessário, uma vez por ano, escrever ofícios pelos irmãos já falecidos, que deveriam ser escritos depois da festa de Nossa Senhora do Rosário, para que as almas dos defuntos fossem encomendadas.

\section{Cargos dos Irmãos}

Assim como nos primeiros capítulos onde foram estipulados os cargos dos irmãos e também como devem se comportar as pessoas que ocuparem tais cargos, nos capítulos mais a frente, as funções dos cargos são descritas mais detalhadamente, além de haverem funções gerais destinadas aos irmãos que não possuem um cargo específico na irmandade.

Primeiramente, o irmão denominado "andador" ou zelador, deve ser formado para a condução de cartas ou qualquer outro documento que a mesa lhe determinar, 
além de ter boa vontade. Em sequência, o cargo de Juiz é descrito como o cargo de maior prestígio para a irmandade, onde o eleito deve doar a irmandade uma esmola de oito mil réis, sendo que entre suas funções, este deve:

\begin{abstract}
"Será obrigado o Irmão Juiz da Mesa a ver todas as vezes que for chamado para dar assistência da Mesa que ouverem naquela terá sempre o primeiro lugar, e da mesma maneira nas procissoes e enterros, nos quaesprezidirá sempre com a vara na mão.[..] em nenhum tempo conservará em seo puder dinheiro algum da Irmandade porque só este pertence ao Irmão Procurador para delle fazer entrega ao Irmão Tezoureiro para que tão bem o dito o destitua em Mesa perante os que nella se acharem e assim nada disporá."
\end{abstract}

A próxima descrição do compromisso é sobre o cargo de Escrivão:

“O Irmão Escrivão fechará os livros e os mais papéis da Irmandade e nelles cumprirá com a sua obrigação nos assentos dos Irmãos que de novo entrarem, e lançará as contas que ouverem nos livros que lhes competir dando-as e tomando-as em presença de toda a Meza a nenhum tempo poderá particularmente a Isentar Irmão algum sem que prezencie os demais da Mesa, e de cuja entrada fara termo no livro delles na conformidade e ordenação deste comrpomisso, e só fará entrega dos sobreditos livros no fim do anno de seo governo ao Escrivão sucessor que se eleeger, por que desta sorte se evitão as mas suspeitas e dellas se dezonera sobredito escrivão e conclue o seu anno sem nota nem defeito:

Ultimamente segue-se o lugar do Juiz da Mesa, como segunda pessoa depois d Irmão Juiz."

É possível perceber na descrição dos cargos da Irmandade que existia uma hierarquia bem marcada entre os cargos, como explicitado acima, o cargo de Escrivão era o posto diretamente inferior ao posto de Juiz da Mesa. As próximas funções a serem descritas são as de Procurador, que assim como os outros cargos, deveria procurar zelar pela irmandade, além de visitar a irmandade todos os dias, tomar as providências necessárias caso o juiz não esteja presente, além disso, o procurador é responsável por tomar conta das esmolas que serão deixadas na porta da casa e dos demais indivíduos que se oferecerem para doar todos os meses para a irmandade. $\mathrm{O}$ cargo de tesoureiro é obrigado a atender prontamente a mesa quando convocado para receber o dinheiro da irmandade, enquanto o sacristão deverá zelar pela limpeza da igreja, tocar os sinos da igreja quando necessário e tomar conta das chaves. 
É notável na descrição dos cargos, a exigência da devoção e empenho por Nossa Senhora do Rosário e o empenho que cada irmão deveria ter com a Irmandade, assim como já comentado neste capítulo. O papel das irmandades de pretos era bastante importante na vida dos que vieram através da diáspora, a instituição representava um local de inserção e de construção de identidades. Ao serem membros da Irmandade do Rosário dos Pretos de Goiana, estes indivíduos buscavam além de aconchego espiritual, a criação de laços de solidariedade, o que se fazia possível através da instituição. ${ }^{46}$

Sem dúvida, a Irmandade do Rosário dos Pretos, exerceu um papel muito importante na organização da Vila de Goiana e foi uma confraria bastante organizada e empenhada na devoção de Nossa Senhora do Rosário. Através do compromisso conseguimos enxergar uma série de vestígios que nos explicam bastante sobre o modo de vida da população e como estes se enxergam perante a devoção espiritual.

\section{Irmandade de Bom Jesus dos Martírios dos Pretos de Recife}

A organização do compromisso dos irmãos dos Martírios é dividida em capítulos, onde em cada capítulo é abordado um aspecto da irmandade com organização muito parecida com a Irmandade do Rosário dos pretos de Goiana.

No primeiro capítulo, é estipulado que em cada ano, no dia 3 de Maio, dia da invenção da Santa Cruz, serão realizadas as comemorações do Senhor Bom Jesus dos Martírios com as suas devidas ritualísticas e festividades, além de ser a data escolhida para a eleição anual dos cargos da Irmandade. ${ }^{47}$

\footnotetext{
${ }^{46}$ LIMA, Maria da Vitória Barbosa. Liberdade Interditada, Liberdade Reavida: escravos e libertos na Paraíba escravista (século XIX) - Brasília: FCP, 2013, p.90.

${ }^{47}$ Compromisso da Irmandade do Senhor Bom Jesus dos Martírios dos Pretos da Villa de Santo Antônio do Recife de Pernambuco. (1788) - AHU_ACL_CU-Códice. 1913. p.3. capítulo I.
} 
Já no segundo capítulo, é explicitado o modo como se fazia a eleição dos cargos, que deveria acontecer sempre no primeiro dia do mês de Maio, escolhendo os irmãos que deverão servir a Irmandade no ano seguinte. $O$ costume da irmandade era acender duas velas para o Senhor Bom Jesus dos Martírios e através dos procuradores, convocar todos os provedores, fundadores e os outros irmãos, para que pudessem ser realizadas as eleições para os irmãos da mesa. Além dos cargos citados acima, no mesmo capítulo também é definida a escolha dos mordomos, que deveriam ser doze e precisavam passar pelo crivo dos provedores e fundadores da irmandade, além de existir a necessidade de que os indivíduos que desejassem ocupar o cargo, fossem capazes de pagar suas multas e não estivessem devendo encargos.

Além das especificações dos cargos escolhidas pela eleição anual, é muito interessante notar que na quarta página do compromisso, os irmãos pretos dos martírios atentam para o fato de que se eleja para provedores, escrivães, procuradores, entre outros cargos, irmãos que de preferência sejam libertos, saibam ler, escrever e contar. É importante ressaltar que a mesa deve ser composta especificamente por indivíduos libertos para que a irmandade seja vista com autoridade. $^{48}$

No capítulo seguinte é descrita de maneira detalhada a cerimônia de posse da nova mesa, repetindo mais uma vez os cargos existentes na irmandade e suas respectivas funções e obrigações perante a devoção.

O capítulo VI aborda o modo que a Irmandade deve lidar com os Irmãos defuntos, sendo que qualquer irmão deve ser enterrado na igreja com a sua tumba, sem abordar por enquanto, maiores detalhes. Em seguida sobre as normas a respeito dos bens da irmandade, explicando que todos os bens, sejam eles doados por vivos ou por defuntos, deveriam ser registrados nos livros de receitas ou no de despesas cotidianas da Mesa, para que assim pudesse existir um controle a respeito das finanças da irmandade.

\footnotetext{
${ }^{48}$ Idem.capítulo II.
} 
Ao longo do compromisso também é alertado sobre como deve ser o tratamento da irmandade com aqueles que não são irmãos. Estes não irmãos poderiam ser enterrados na igreja do Bom Jesus dos Martírios dos Pretos, porém, deveria pagar um preço estipulado pela irmandade.

Por último, o capítulo XVII encerra o compromisso e explica que o este regimento deve ser lido em todas as mesas e os irmãos não devem de maneira alguma ignorá-lo e devem sempre cumprir com as obrigações descritas ao longo do documento para que assim seja possível o bom funcionamento da irmandade.

\section{A importância dos Compromissos}

Ao analisar as particularidades de cada um dos compromissos são encontradas várias semelhanças entre eles, na maneira de organização da fonte, na forma de escrita, confirmando o fato de que esse tipo de documentação seguia um padrão exigido pelo governo colonial e pelo poder eclesiástico que regulamentava o funcionamento das Irmandades católicas no território colonial.

O compromisso dos irmãos de Goiana, separado em XL capítulos, onde são descritos de maneira bastante específica e detalhada os deveres e costumes da irmandade se mostra muito mais detalhado do que o compromisso do irmãos de Recife, que dispõe de XV capítulos, no qual é falado brevemente sobre os costumes da irmandade, apresentado apenas algumas regras gerais.

É interessante notar que as duas irmandades funcionavam regularmente, portanto, os dois compromissos foram aceitos pelas autoridades eclesiásticas mesmo diferindo bastante quanto o detalhamento dos conteúdos nos dois documentos. Essa afirmação traz a reflexão a respeito de quais seriam os pré-requisitos que deveriam conter nos compromissos para que eles fossem aceitos? Ou qual seria a flexibilidade das autoridades ao aceitarem o pedido das irmandades de pretos? Voltando os questionamentos para o interior das irmandades, pode-se aferir que a Irmandade de Goiana deixava mais explícito os seus costumes e formas de organização enquanto a 
Irmandade de Recife preferia se restringir em tornar público apenas o necessário para sua autorização perante a igreja católica.

De acordo com os procedimentos indicados por Seignobos e Langlois como foi explicitado no início deste capítulo, a documentação analisada se mostra verídica e não foi modificada pela tradição ou não nos mostra indícios de falsificação, já que ao serem comparados os dois compromissos: o da Irmandade da Nossa Senhora do Rosário dos Homens Pretos de Goiana, com o da Irmandade do Bom Jesus dos Martírios dos Pretos da Vila de Recife, pode-se perceber que estes seguiam padrões de organização e de escrita, assim como compromissos de irmandade das outras organizações localizadas em diferentes lugares do território da América Portuguesa.

Ainda através dos parâmetros indicados pela análise crítica os textos analisados são originais, não sendo assim possível existir algum tipo de transformação ou modificação dos textos através de traduções ou de cópias. Existem também outros perigos além da falsificação de documentos, como o do falso testemunho, que é realizado de acordo com a intenção de quem estava oferecendo o testemunho e de quem estava registrando o testemunho. Para a documentação analisada, este tipo de julgamento a respeito do falso testemunho se torna um pouco complicada, pois os compromissos são documentos utilizados para fins burocráticos exigidos pela igreja católica, portanto, seguem um padrão a ser reproduzido, não abrindo espaço para novos tipos de relatos e testemunhos a respeito das irmandades.

O que pode ser extraído a partir desse ângulo de análise, focando a observação na Irmandade de Goiana, é o respeito e a obediência aos parâmetros colocados pela igreja católica para as normas impostas, documentados em seu compromisso. Para que se torne possível a análise das práticas cotidianas da Irmandade, seriam necessárias análises de outros tipos de documentos, não apenas o compromisso de fundação da Irmandade. 


\section{Capítulo 2 - Linguística e método histórico}

A análise de fontes históricas pode ser auxiliada por diferentes metodologias, algumas vezes por práticas trazidas de outras disciplinas externas para a História. Desta maneira, este capítulo tem como objetivo apresentar e aplicar métodos trazidos da linguística, que podem auxiliar o trabalho com as fontes documentais.

Logo no início do texto "História e Análise de Textos", de Ciro Cardoso e Ronaldo Vainfas, é explicitado que já no século XIX, a leitura de textos e sua interpretação era realizada com a preocupação de se encontrar informações diretas a respeito de seu conteúdo e sua intenção, sem levar em consideração o movimento de analisar o que não era dito diretamente em um texto ${ }^{49}$, o que poderia ser extraído de uma interpretação a partir da contextualização do texto da fonte com o período temporal e ambiente social e político no qual a fonte foi redigida. Além de cuidados sobre a finalidade de tal escrita e para quem a leitura era direcionada.

O texto nos explica que a interpretação clássica dos historiadores para com os textos estudados como fonte, tem maior interesse, predominantemente, nos conteúdos, acatando os documentos como suporte para a informação que se necessita. Partindo dessa prática, pode-se compreender que esta concepção acredita que através da leitura exaustiva do texto, podemos compreender o seu sentido, o que pode tomar a análise de um texto bastante rasa, não explorando assim, as capacidades de nuances a serem explorados do tal documento analisado. ${ }^{50}$

Desta maneira, é exposto um panorama, explicando de maneira sucinta, sobre como este intercâmbio entre a História e a Linguística se desenvolveu ao longo do tempo, colocando a lexicologia para realizar a divisão dos termos expostos nos textos documentais, para desta maneira, enxergar como estes termos se organizaram,

\footnotetext{
${ }^{49}$ CARDOSO, Ciro Flamarion. VAINFAS, Ronaldo. História e análise de textos. In: CARDOSO, Ciro F. ; VAINFAS, Ronaldo (Orgs.). Domínios da História. Ensaios de teoria e metodologia. Rio de Janeiro: Campus, 1997. p. 375.

${ }^{50}$ Idem. p. 376
} 
com o objetivo de tornar a troca entre as duas disciplinas proveitosa para o estudo Histórico.

Desta maneira, Vainfas e Cardoso definem:

"O discurso pode ser definido de diferentes modos como sinônimo de fala (uso contingente da língua) em oposição à língua (sistema estruturado de signos); como unidade linguística maior do que a frase - torna-se então sinônimo de mensagem ou enunciado; como conjunto das regras de encadeamento das frase ou grupos de frases que compõem um enunciado; ou como o enunciado visto a partir das condições de produção - linguísticas e sociais - que o geraram.

A análise do discurso assim concebido - sobretudo nas duas últimas acepções listadas acima - pode efetuar-se: pela semântica, teoria do conteúdo das significações ou, como agora passou a preferir-se, estudo das mencionadas significações que seja ao mesmo tempo gerativo (investimentos sucessivos de sentido em patamares diferente), sintagmático (e não unicamente classificatório) e geral (não atado com exclusividade a um único sistema significante); ou pela semiótica, que se ocupa da expressão das significações e de sua produção, em outras palavras, em especificar como se chega a significar alguma coisa."

Para trabalhar a análise de textos no âmbito da pesquisa histórica é necessário afirmar o pressuposto da metodologia de análise de textos, que considera todo documento como condutor de um discurso, sendo assim, o documento histórico não pode ser analisado com um olhar inocente. Inocente, no sentido de que não podemos deixar de lado o fato que de as palavras que compõem o texto estudado,não trazem por si só a mensagem do texto. Além disso, o texto carrega consigo uma ideologia, uma intenção expressa através de toda construção textual. Sendo assim, ao se debruçar sobre tais tipos de texto, o historiador deve estar bastante atento a forma do texto, ao vocabulário, aos enunciados e todos os outros detalhes existentes na fonte.

Mesmo existindo trocas bastante interessantes entre a Linguística e a História, os autores nos alertam para alguns perigos de interpretação que podem ocorrer ao se utilizar da semântica em textos históricos. Alguns autores, ao interpretarem parâmetros linguísticos de maneira extrema, acabaram reduzindo a

${ }^{51}$ Idem. p.380, 381 
capacidade explicativa da história, tornando a disciplina histórica um gênero engessado em estruturas discursivas. Para que tais erros não sejam cometidos é necessário sempre tomar o cuidado de não reduzir um texto histórico apenas a estrutura discursiva na qual o texto se encontra. ${ }^{52}$

Sendo assim, Ciro Cardoso, nos explica que antes de fazer o intercâmbio entre as duas disciplinas, a linguística e a história, devemos buscar as conexões entre as idéias do discurso. Além de analisar o texto, o historiador deve sempre se atentar para o fato de que o texto e seu discurso, seu sentido, devem ser relacionados com o contexto social, político e temporal no qual eles estão inseridos. ${ }^{53}$

Desta maneira, a análise da fonte não pode tomar o texto e sua forma como elemento principal e de sentido completo, sem considerar o discurso e como tal discurso está inserido dentro de seu contexto social e político, não podemos reduzir o texto a sua estrutura. Ao mesmo tempo, também devemos refletir com cuidado a respeito das condições de produção de uma fonte, sobre a motivação ideológica de um discurso, como ele é produzido ideologicamente e como é recebido, sendo aceito ou não pela sociedade. ${ }^{54}$

Para facilitar a compreensão em termos didáticos, Ciro Cardoso resolve explicar sobre como tais pressupostos teóricos foram aplicados na disciplina histórica, utilizando como fio condutor algumas metodologias utilizadas na obra de Régine Robin, "História e Linguística".

Robin, inicia chamando atenção para as motivações do livro, com o objetivo de alertar que seu estudo pretende alertar o leitor para os perigos de equívoco que podem acontecer quando tratamos da relação entre a linguística e a História. Sendo assim, ao longo de sua obra são expostos exemplos sobre como abordar documentos históricos, trazendo conhecimentos da linguística para o estudo. A autora explica

\footnotetext{
52 Idem. p.384

53 Ibidem.

${ }^{54}$ Idem. p.385
} 
que durante muito tempo, a linguística desempenhou um papel essencial como mestra das ciências humanas, como chave de método, modelos, conceitos e signos. ${ }^{55}$

O quadro da linguística nos estudos históricos não se trata de exportar modelos, nem conceitos, o que se faz necessário conservar, além do que é colocado em causa, é a lição sobre a prudência ao se analisarem os documentos, a atenção contra todo uso metafórico dos conceitos da linguística, toda analogia não rigorosa, além de ser necessário o exercício de banir a possibilidade de se utilizar do movimento negligente, de se apropriar de conceitos linguísticos sobre a análise histórica dos discursos em questão. ${ }^{56}$

\begin{abstract}
“O Historiador não considerava a Linguística como uma moda, em fim em si, um modelo inexportável, com vistas analogias não rigorosas. Isto implica que um tal campo de aplicação deva ser precisado cuidadosamente, bem como seus limites. A linguística permita substituir o dado do texto por uma lógica do texto. Serve apenas para revelar a economia interna de uma ideologia, em caso algum para estabelecer sua função social. Daí a prudência, as apalpadelas com as quais o historiador deve articular estes dois domínios heterogêneos mais ligado ( o conteúdo de uma ideologia, bem como sua contradições: sua função no campo das lutas de classe de uma formação social); daí, os resultados parciais, a serem sempre retomados...,
\end{abstract}

Para encontrar a função de uma ideologia é preciso sair do texto e passar da linguística para a história, compreendendo os movimentos entre as duas disciplinas. A linguística descreve o texto, traz a ordem pra ideologia, enquanto isso, a disciplina histórica é quem nos diz que sobre a função da ideologia dentro do período estudado e o contexto no qual o documento está inserido. Desta maneira, a ambição do historiador para com a linguística é modesta, o estudo da História pede que a linguística ensine o historiador a ler o que está contido no texto, a desbravar seu conteúdo e a ordená-lo. ${ }^{58}$

Tal intercâmbio entre as duas disciplinas é necessário devido a complementaridade que a linguística pode trazer a análise do discurso histórico, por

\footnotetext{
${ }^{55}$ ROBIN, Regine. História e lingüística. São Paulo: Cultrix, 1977 p.17

${ }^{56}$ Idem. p.18

${ }^{57}$ Idem. p.19

${ }^{58}$ Idem. p. 20
} 
conta de sua capacidade de trazer novas formas de interpretação não possíveis apenas com o arcabouço teórico da disciplina histórica. É necessário procurar um sentido contextualizado historicamente, palavras contidas no documento histórico, procurando seu sentido coletivo e particular. Robin nos explica que o que está contido no texto além da escrita, não intervém na análise do texto, desta maneira a relação entre o universo linguístico, escrito e o universo cultural e social no qual a fonte está inserida é realizada através de correlações, remetendo a sociolinguística. ${ }^{59}$

A respeito da língua e o discurso especificamente, Robin expõe que separando a língua da fala é possível distinguir dois conceitos, é possível fazer uma separação do que é social, do que é individual e do que é acessório, além de separar o que aparece registrado acidentalmente. Essa distinção é possível, devido ao fato de que a língua é registrada pelo indivíduo de maneira passiva, enquanto que a fala é um ato que depende das vontades e necessidades individuais. Deste modo, faz-se necessário analisar o motivo das combinações utilizadas da língua para exprimir um pensamento pessoal.

\footnotetext{
"Digamos, numa primeira aproximação, que o historiador não tem que lidar com o código, com a língua, ou antes, tem que lidar com eles, mas como base, como matériaprima; seu objeto no entanto, se ele se considera historiador das manifestações, dos efeitos ideológicos, não é o sistema, o modelo de competência, a língua, mas fatos de fala precisos, ficando entendido que convém desembaraçar o termo de suas conotações filosóficas precedentemente evocadas - numa palavra, dos discursos." 60
}

Sobre o discurso, segundo o autor, o que se procura dentro do campo de estudo da História, é a possibilidade de trabalhar com novos objetos de estudo, se contrapondo ao positivismo linguístico e pontuando as insuficiências de uma análise interna ao se analisar um discurso, pois estas análises internas não podem ser a única alternativa para a interpretação de um discurso. Um discurso deve ser estudado de maneira que possa se enxergar suas ideologias. ${ }^{61} \mathrm{~A}$ importância deve se voltar a

\footnotetext{
${ }^{59}$ Idem. p.23

${ }^{60}$ Idem p.26

${ }^{61}$ Idem. p.27
} 
atenção para a substância do discurso, além de prestar atenção na diferenciação entre a língua e a fala, nos elementos que transformam um discurso e os diferentes tipos de formações discursivas. O estudo deve ser realizado integrando elementos da linguística, da história e da sociologia.

"O discurso é sempre relacionado com a suas condições de produção - o que, aliás, autoriza toda escolha de corpus a analisar. Esta linguística do discurso integra ao seu objeto tudo o que ultrapassa a simples lógica da comunicação denotativa. Pretende estar atenta ao universo conotativo da linguagem, ao jogo das implicações e das pressuposições, a tudo enfim que está no campo da enunciação. Ela assinala igualmente como seu objeto o campo retórico-estilístico, a estratégia dos argumentos do discurso, sua estrutura, enfim. Todos estes tipos de estudos, dos quais alguns estão malesboçados, devem permitir ultrapassar a análise de enunciados e fazer estourar o espartilho que apertava o objeto linguístico. A Linguística vive, aliás, a hora das revisões fundamentais." 62

Antes de expor os métodos de análise qualitativa utilizados para analisar o compromisso dos irmãos de Goiana, torna-se importante trazer alguns conceitos expostos por Robin, que esclarece sobre a análise textual utilizada pela disciplina da História:

"A Lexicologia (que) é, como veremos, uma disciplina sociológica, encara grupos de palavras consideradas estatisticamente do ponto de vista nacional... A lexicologia tem pois por objeto, como a sociologia, o estudo dos fatos sociais... É partindo do estudo do vocabulário que tentaremos explicar uma sociedade. Assim poderemos definir a Lexicologia como uma disciplina sociológica que utiliza o material linguístico constituído pelas palavras... A lexicologia social pode efetivamente ser considerada como aquela que oferece, não um objeto novo (é o mesmo que o da sociologia), mas um ponto de vista particular..." ${ }^{63}$

A lexicologia tem como objetivo a tentativa de aproximar a Linguística, a Sociologia e a História, sendo que aplicada na História traz um panorama de análise

\footnotetext{
62 Idem. p.88

${ }^{63}$ Idem. p.40
} 
que não permite a aceitação perigosa, como já dito anteriormente, do que está escrito na fonte de maneira inocente, permitindo a análise qualitativa das palavras descritas na fonte, essenciais para compreender o discurso disseminado através do documento.

Mesmo fora do seu campo de metodologias tradicionais, as relações lingüísticas atraem o olhar dos historiadores, que adaptam ao seu campo de trabalho:

\begin{abstract}
"Não possuindo uma formação específica quanto ao que concerne aos problemas da sintaxe ou da semântica, eles dirigem sua atenção para o léxico. É através dele que pensam escapar dos postulados da imediatez do sentido e da transparência das palavras. Para tanto, formulam uma nova hipótese; a de um isomorfismo entre grupos sociopolíticos e o léxico. Cada grupo político seria assinalado pelo uso específico que faria de certas palavras. Colocadas e conhecidas as atitudes políticas, espera-se, deseja-se que lhes correspondam clivagens linguísticas - mais exatamente, léxicas pertinentes. O vocabulário seria assim uma espécie de etiqueta fixada sobre cada grupo político, na qual se desdobraria uma visão de mundo coerente, uma linguagem específica. Aliás, não seria necessário conhecer a posição política deste ou daquele; seu vocabulário bastaria para definí-lo, para designar-lhe um lugar específico no tabuleiro político." ${ }^{4}$
\end{abstract}

Assim como descrito por Robin, a análise da formação do léxico da fonte documental permite uma classificação do vocabulário de acordo com os termos do texto, que podem trazer esclarecimentos sobre o contexto social histórico que está sendo analisado.

Ainda falando a respeito da relação dos historiadores com a linguagem de fonte e como o documento deve ser analisado no sentido de se compreender seu sentido, além do que está explícito nas palavras, Regine Robin traz a idéia do método de abordagem temático, onde o pesquisador deve delimitar o seu domínio exploratório subdividido em categorias temáticas, desta maneira, a citação ilustrativa depende do critério de escolha do historiador. O autor ressalta que se torna inútil, na análise, o movimento de se ater demais a termos que se mostram como "evidências semânticas" quando ao invés de elucidarem sobre o discurso, fazem o caminho

${ }^{64}$ Idem. p.43,44. 
inverso, causando um problema maior, procurando a origem, o "instinto" ou a "verdade histórica", o que deve ser analisado com atenção e a função polissêmica dos termos expostos na fonte. ${ }^{65}$

A investigação dos conteúdos pode ser realizada através de algumas categorizações, estas podem ser análises exaustivas, onde todo o texto, o conjunto de palavras deve ser observado e através de análises exclusivas, onde as palavras, ou elementos analisados não pertencem a categorias diferentes, sem relações de intersecção ou inclusão. A categorização objetiva, onde a escolha da categoria não pode depender da personalidade e da escolha subjetiva do codificador, os elementos devem ser classificados nos mesmos parâmetros. Já a categorização realizada pela pertinência, deve ser feita em relação ao conteúdo que está sendo estudado, e não de acordo com critérios pré-estabelecidos, necessitando previamente de uma leitura atenta e minuciosa do texto. Partindo desse cuidado na análise, o resultado pode se dar de diversas formas, dependendo a quais sinais os quais o estudioso pode se focar. ${ }^{66}$

Em seguida, Robin nos explica como os métodos de abordagem linguísticos podem ser utilizados para otimizar o trabalho do historiador. No caso específico exemplificado na obra, quando F. Lebrum pesquisou a respeito da morte e das atitudes diante a morte em Anjou, no séculos XVII e XVIII, o autor se debruçou sobre os "discursos de sermões, mandamentos do bispo, os sínodos, as conferências eclesiásticas da diocese d'Angers, os catecismos, os "livros de Razão", os testamentos, os rituais, os estatutos das confrarias dos moribundos, as coleções de orações, a literatura culta, a literatura dos vendedores ambulantes, os manuais de ensino elementar, etc."67

Assim, o pesquisador procurou diferenciar a morte e a pobreza como fenômeno social e suas ideologias, porém mesmo com uma vasta variedade de fontes, Robin acredita que este método não esgotou as possibilidades de investigação de maneira satisfatória.

\footnotetext{
${ }^{65}$ Idem. p.62

${ }^{66}$ Idem. p.63

${ }^{67}$ Idem. p.100
} 


\begin{abstract}
"Quando eles analisam certas fontes (sermões, "livros de razão", literatura de mendigos ou tratados teóricos), as categorias temáticas colocadas em jogo não parecem esgotar a riqueza de tais fontes. É que o método temático, como já dissemos, atravessa a estrutura linguística do texto, sua materialidade própria, que é feita de palavras escolhidas e combinadas. Sendo assim, são negligenciadas a estrutura sintática do texto, o léxico específico, a rede semântica que se tece entre vocábulos. São eludidos, da mesma maneira, o nível próprio do discurso, sua estrutura, sua estratégia de raciocínio, sua retórica, os mecanismos de enunciação pelos quais o sujeito falante intervém no discurso. Em suma, os textos só são utilizados por seu conteúdo, com o postulado inicial e implícito de que o conteúdo é unívoco, que a simples leitura dá conte dele em sua plenitude. Assim, as rupturas constatadas são rupturas de conteúdo, não rupturas discursivas, formais ou retóricas. Procura-se através do discurso, uma coisa diferente da prática discursiva. ${ }^{68}$
\end{abstract}

Desta maneira é interessante enxergar que toda e qualquer literatura do período localizado geograficamente e temporalmente, pode ser útil quando se trata de discursos produzidos a respeito da sociedade estudada.Resta descobrir se o método temático descrito por Robin, ultrapassa as expectativas, no sentido de elucidar nuances sobre a documentação trabalhada na disciplina histórica.

\title{
Método Estatístico
}

O Método estatístico do Laboratório Lexicométrico da E. N. S. de SaintCloud, Cardoso nos explica que, segundo Robin, este método tinha como objetivo aperfeiçoar métodos buscando uma interpretação quantitativa de um texto.

Para começar uma análise por meio deste viés, primeiramente, deve-se fazer um inventário exaustivo do corpus do texto, das formas e de suas referências. Mais adiante, o autor explica que o inventário das formas era realizado através da organização de cartões onde cada qualidade se referia a um código preestabelecido, onde também e citado de maneira bastante detalhada, os processos posteriores, que são de transferências das informações do cartão para o computador. Em diante, é

\footnotetext{
${ }^{68}$ Idem.102
} 
destacado o fato de que devido aos programas de indexação e as novas tecnologias, foi possível se conseguir de maneira simplificada, estatísticas a respeito da freqüência relativa ou freqüência total de termos em textos, coeficientes gerais, entre outras informações. ${ }^{69}$

Tal metodologia consiste sua prática em inventariar exaustivamente o texto o qual está sendo analisado e posteriormente, sejam estabelecidos critérios para as listas de frequência das palavras do texto. Sendo que foram divididas de tal maneira:

“... devem ser distinguidas três zonas "arritmosemânticas": $1^{\text {a }}$ ) as palavras-tema (as 50 ou 100 palavras mais freqüentes do corpus examinado), o que perfaz cerca de $9 \%$ do discurso; $2^{\mathrm{a}}$ ) as palavras da base (as 4.000 palavras que vêm em seguida), consideradas a substância do discurso; $3^{a}$ ) as palavras de baixa frequência ou palavras de caracterização (as seguintes 20.000 palavras mais frequentes), consideradas de grande restrição de sentido e muito precisas. Estabelecidas as listas e índices, o pesquisador deve agrupar todas as formas que pertencem a um mesmo lexema, operação chamada de lematização, para em seguida verificar as relações entre palavras-tema e palavras lematizadas, as coocorrências etc.",70

Sendo assim, tal método exige do historiador o auxílio de bases de dados e computadores para se seja possível a organização e a análise das palavras que fazer parte do universo do texto que está sendo analisado.

O autor ressalta a importância de se trabalhar com o critério de frequência, chamando atenção para a necessidade de se ter essa noção, enquanto que ao mesmo tempo, assume que essa noção sozinha, se mostra insuficiente para a investigação. ${ }^{71}$ O estudo da distribuição, aparece como um complemento para o estudo da frequência.

Ao se analisar a distribuição das palavras em um conjunto específico, se estabelece um índice de distribuição, a partir daí torna-se importante questionar qual

\footnotetext{
${ }^{69}$ Idem p.138

${ }^{70}$ CARDOSO. e VAINFAS. Op.Cit. p.376

${ }^{71}$ ROBIN. Op.Cit. p.143
} 
o índice, relacionando com à frequência absoluta. Sendo assim, faz-se necessário a criação de um mecanismo que consiga mensurar tais valores, apesar de tal empreitada ter sido discutida sem sucesso por vários linguístas, devido a dois fatores:

O primeiro deles é que o emprego das formas linguísticas depende do tamanho do texto que será sendo analisado, da forma de escrita adotada, da ligação entre o locutor e o receptor, sendo assim, só é possível analisar a frequência, de acordo com os referenciais dos quadros de enunciação. O emprego destas formas linguísticas citadas acima, é resultante da generalidade de um termo, e se este termo faz parte do vocabulário comum dos comunicantes da época em questão, enquanto também é resultado da particularidade, se está caracterizando um acontecimento ou se é produto de um locutor individual ou coletivo. Desta maneira, o exercício consiste em determinar as palavras gerais e as palavras particulares. ${ }^{72}$

\section{Abordagem dos Campos Semânticos}

O segundo método a ser explanado por Cardoso, partindo de Robin, é o Método de abordagem dos campos semânticos do Centro de Lexicologia Política de Saint-Cloud. A partir desta análise, este método se mostra mais qualitativo do que quantitativo, pois Robin nos explica que o problema no momento da aplicação do método sobre como escolher as palavras que serão consideradas "as mais importantes".

O trabalho de J. Dubois, Vocabulaire politique et social en France é utilizado como exemplo da metodologia e partindo deste ponto, o trabalho do historiador pode ser dividido em algumas categorias importantes para a organização da relação entre as palavras. Sendo assim, as divisões são entre as relações de oposição, relações de associação e de identidade. As relações de oposição são marcadas por pares de palavras contrárias no seu sentido, enquanto que as classificadas como "relações de associação e de identidade são permeadas pelo contexto do

\footnotetext{
${ }^{72}$ Idem.p.144
} 
texto". ${ }^{73}$ Desta maneira, esse tipo de aplicação do método se faz bastante interessante para o trabalho do historiador, já que não exige um aprofundamento dos conhecimentos linguísticos, se tornando disponível através da análise das categorias de relações das palavras expostas acima.

Além disso, Robin coloca uma alternativa na análise semântica, para se fazer a escolha das unidades de registro, sendo que, estas são escolhidas conforme a necessidade do historiador. Algumas categorias são colocadas como exemplo, como: a palavra, o tema, o objeto e o referente, o personagem, o acontecimento e o documento. ${ }^{74}$ Em relação a unidade de contexto:

\footnotetext{
"... Bardin a define como "unidade de compreensão para codificar a unidade de registro', cujas dimensões devem ser ótimas e amplas para 'que se possa compreender a significação exata da unidade de registro'. Traduzida historicamente, a unidade de contexto diz respeito à totalidade, ao 'contexto histórico', às estruturas sociais e/ou ao universo simbólico no qual se insere(m) o(s) discurso(s) analisado(s). Trata-se de uma unidade "arbitrária, posto que extratextual, que somente o historiador pode determinar, conforme suas opções teóricas, suas escolhas temáticas e suas hipóteses de investigação." ${ }^{75}$
}

Como já dito anteriormente, a metodologia de abordagem focada nos campos semânticos do documento estudado em questão se faz bastante interessante para o trabalho do historiador, porém, Cardoso nos chama atenção para o cuidado que historiadores devem ter com esse método, sobre os resultados de sua produtividade, que algumas vezes pode trazer resultados já sabidos antes mesmo do início da análise semântica. Isso não quer dizer que a análise semântica não deve ser utilizada como método, porém seus resultados serão mais proveitosos se tais práticas forem utilizadas com criatividade, lembrando que uma muito da pesquisa histórica se faz com o referencial do pesquisador que a realiza e as suas necessidades. ${ }^{76}$

\section{O discurso do compromisso dos irmãos de Goiana}

\footnotetext{
${ }^{73}$ CARDOSO. e VAINFAS. Op.Cit. p.376

${ }^{74}$ Idem. p.379

${ }^{75}$ Idem. p. 378

${ }^{76}$ Idem. p.379
} 
A partir da análise qualitativa do compromisso da Irmandade da Nossa Senhora do Rosário dos pretos de Goiana, podemos analisar de maneira mais específica a forma como o texto se constrói, entre outras variantes. Desta maneira, o objetivo é verificar se a análise linguistica traz informações diferentes e possibilitam novas interpretações para o documento.

O compromisso é um documento construído exclusivamente para ditar o regulamento dos irmãos e é usado para reivindicar o direito de funcionamento com as autoridades eclesiásticas. Assim sendo, pode-se perceber que o documento é bastante centrado nele mesmo e nas suas regras que definem sobre desde quem pode se tornar irmão ou não, até as penalidades que podem ser sofridas caso os irmãos não cumpram seus afazeres ou façam de maneira errada.

É importante ressaltar que o compromisso é localizado historicamente na segunda metade do século XVIII, mais precisamente datado do ano de 1783, o que já auxilia a compreender o seu contexto de produção.

Neste período, as irmandades negras eram subordinadas as autoridades eclesiásticas, de maneira que dependiam da coroa portuguesa para o seu funcionamento e eram espaços onde os senhores davam permissão para que os seus escravos pudessem ser membros dos irmandades, já que representavam um lugar de promoção da fé católica. Ao mesmo tempo, para os integrantes das irmandades negras, a organização também funcionava como um espaço de organização política e resistência. $^{77}$

A contextualização do período histórico e social permite uma melhor compreensão do compromisso. O documento aborda unicamente as cláusulas necessárias para que as autoridades autorizem o funcionamento da irmandade, não incluindo informações a mais a respeito do que acontecia no interior da irmandade.

\footnotetext{
${ }^{77}$ ALVES, Naiara Ferraz Bandeira. Irmãos de cor e de fé: irmandades negras na Parahyba do século XIX. UFPB, 2006.p.44
} 
$\mathrm{O}$ fato do compromisso trazer detalhadamente as regras que iriam reger a irmandade demonstram a importância dada a autorização da coroa portuguesa, porém, ao mesmo tempo, ao longo de todo o documento, não são explicitadas as práticas da irmandade. Quando o documento fala a respeito das festas, do sepultamento de irmãos entre outras práticas cotidianas, estas práticas não são expostas detalhadamente, como por exemplo quais orações e rituais serão realizados nestes momentos.

A falta de detalhamento ou a omissão destes rituais demonstra que os irmãos não viam a necessidade da descrição de tais práticas, um possível sinal de que as autoridades eclesiásticas não exigiam tais descrições no compromisso. Além disso, tal omissão traz uma reflexão a respeito das práticas existentes no interior das irmandades, com atividades de organização política, social e religiosa, bastante exploradas pela historiografia. Se restringindo apenas ao Compromisso dos irmãos pretos do Rosário de Goiana, não tenho a possibilidade de explorar maiores indagações a respeito das práticas que não estão explicitas no compromisso através da metodologia qualitativa.

Ainda analisando o discurso do compromisso dentro de sua conjuntura de elaboração, nota-se que o compromisso todo está redigido com uma linguagem rebuscada, o que exigia um trabalho de conhecimento de um vasto vocabulário por parte do escrivão, além de utilizar uma linguagem específica direcionada as autoridades eclesiásticas responsáveis. Nota-se também que os termos utilizados para se dirigir as autoridades demonstram que o documento foi escrito por alguém que dominava a linguagem da documentação oficial da coroa portuguesa.

Da maneira como está colocado, o compromisso reproduz o discurso necessário para a coroa portuguesa, de aceitação da fé católica e de total rigor em relação ao regimento interno e comportamento dos irmãos.

Por último, torna-se importante salientar que os compromissos das irmandades negras na América portuguesa seguiam um padrão de estrutura e eram bastante parecidos, porém ainda sim, os textos não são meras cópias uns dos outros o que demonstra a obrigatoriedade de conhecimento da forma de escrita oficial e das 
necessidades exigidas para redigir um compromisso para que o compromisso fosse escrito.

\section{Análise estatística}

Para realizar a análise estatística do compromisso foi utilizada a ferramenta online AnaText, desenvolvida pela Université Stendhal Grenoble. O AnaText realiza a análise lexicológica de textos e conta frases, palavras e sílabas, auxiliando o estudo do texto e de seu vocabulário, tornando mais prático o trabalho realizado neste capítulo. $^{78}$

A análise das palavras do compromisso expõem como o texto está construído e quais são os temas mais importantes para o texto demonstrando como ele está voltado para sua finalidade, que é a aceitação de seu funcionamento.

Em relação aos substantivos, os dados nos mostram que o texto é totalmente voltado para a própria irmandade e para demonstrar a sua legitimidade, ou seja, suas principais palavras, as mais repetidas, remetem ao próprio compromisso.

A palavra "Irmandade" é a palavra mais falada no compromisso, utilizada 108 vezes, em seguida vem as palavras "Irmãos" e "Irmão" que respectivamente são faladas, 90 e 75 vezes ao longo do compromisso. Logo depois, em ordem de citação vem as palavras: "mesa" com 70 citações, "Juiz" com 56 citações, "senhor" com 36 citações, "Cap" (referente a Capítulo) com 31 citações, "Santa" com 30 citações, “dia" com 29 citações e "pessoa" com 22 citações.

Tais palavras citadas acima são as mais recorrentes no compromisso e também se relacionam com as cláusulas contidas no compromisso demonstrando que o documento todo se dedica na sua auto-explicação. Assim sendo, as palavras "irmandade" e "irmãos", além todas as suas outras derivações existentes mostram uma necessidade de explicação por parte das autoridades eclesiásticas, já que as duas próximas palavras da lista são "Mesa" e "Juiz", estas palavras foram usadas quase sempre juntas.

\footnotetext{
${ }^{78}$ Ana Text - http://olivier.kraif.u-grenoble3.fr/anaText/
} 
Todos os 10 substantivos mais citados no texto do Compromisso demonstram a preocupação de abordar as regras que deveriam reger a irmandade, além de expor a preocupação de abordar tais regras de maneira específica.

Sendo assim, a análise estatística não traz novas particularidades para interpretação, pois os resultados revelados já eram esperados antes da análise, porém reafirma os questionamentos levantados anteriormente já que os termos levantados pela análise estatística confirmam a afirmação de que o texto é utilizado estritamente para servir como uma autorização.

A utilização de práticas metodológicas trazidas do campo da linguística, se mostram interessantes trabalhadas juntamente com a disciplina histórica, trazendo um panorama a respeito dos temas mais abordados na fonte e explicações a respeito dos assuntos do texto. Tais metodologias também permitem uma visão diferente a respeito da fonte, procurando compreender como o discurso se insere no contexto histórico e social trabalhado e qual o seu papel dentro da sociedade estudada.

Apesar de enriquecedora para o trabalho do historiador, no caso específico da análise do compromisso dos irmãos pretos de Goiana, as metodologias trazidas do campo da linguística afirmaram e deram suporte para as idéias já propostas antes do início de sua aplicação, não trazendo novas particularidades para o trabalho. 


\section{Capítulo 3 - A retórica utilizada para decifrar a leitura do Compromisso}

O exercício de análise da retórica que será o fio condutor da metodologia utilizada neste capítulo se mostra interessante para o estudo da disciplina da história, pois através da análise das fontes históricas e seu discurso, muitas vezes, torna-se possível encontrar traços de comportamentos específicos que não são vistos em outras análises. A análise da retórica permite identificar traços dentro de um determinado discurso e a qual o público está sendo dirigido.

José Murilo de Carvalho explica um pouco sobre a tradição de análise de textos através do estudo da disciplina histórica. Trabalhos sobre a história das ideias, que buscavam explorar pensadores e suas correntes teóricas, foram muito importantes para esclarecimentos de discursos e movimentos ao longo da história, porém tais pesquisadores deixaram a desejar, quando não discutiam a respeito de seu próprio método de trabalho. Estas questões só se tornaram uma preocupação posteriormente, se tornando um objeto nos últimos 50 anos. ${ }^{79}$

Com a aproximação da história com outras disciplinas como as ciências sociais e a filosofia, houve uma mudança no trabalho no sentido de procurar compreender idéias e concepções de grupos sociais. Porém mesmo com análises importantes, ainda continuou havendo uma lacuna, uma restrição neste tipo de trabalho, já que as análises, muitas vezes, tentavam encaixar parâmetros e modelos explicativos dentro de conjunturas que não comportavam tais explicações. ${ }^{80}$

Através desta procura por artifícios que pudessem auxiliar no estudo histórico, a retórica se mostrou como um campo que tem a possibilidade de trazer uma grande contribuição para a história. A retórica possuía uma longa tradição escolástica portuguesa e fora também estudada com afinco nas terras da América

\footnotetext{
${ }^{79}$ CARVALHO, José Murilo de. História intelectual no Brasil: a retórica como chave de leitura. Topoi, Rio de Janeiro, nº 1, jan./dez. 2010. p. 124

${ }^{80}$ Idem. p. 125
} 
Lusa, onde a visão a respeito da retórica era de que se tratava de um campo que não podia se desvincular da lógica e da gramática, a retórica não poderia ser encarada como um instrumento figurativo de argumentação, mas sim, ser estudada a fundo aliando a teoria do conhecimento com a teoria da linguagem. ${ }^{81}$

O tratado de Chaim Perelman e Lucie Olbrechts-Tyteca, trabalha a noção da retórica enquanto um campo de trabalho menosprezado ao longo do tempo, devido a polaridade entre a opinião e a verdade desde Aristóteles e retoma a retórica como uma lógica dos juízos de valor, porém não procura convencer apenas através da lógica, mas sim, se utilizando de vários outros artifícios de persuasão. ${ }^{82}$

Desta maneira, ao longo dos últimos três séculos, com novas concepções acerca da filosofia e da razão, novos paradigmas foram estabelecidos acerca dos estudos sobre textos argumentativos e sobre a retórica, pois a ciência racional não poderia mais se contentar com modelos apenas razoáveis, precisava explicar melhor a argumentação.

$\mathrm{Na}$ concepção das ciências racionais, se fez necessária uma organização em um conjunto de proposições impondo acordos que não permitiam opiniões dissonantes, pois quando tais proposições resultavam em interpretações divergentes, não era alcançada uma única resposta, haveria um desacordo, ou seja, um erro. Em contrapartida, para as ciências experimentais e indutivas, as proposições fechadas não eram o mais importante, mas sim a semelhança da suposição do que é de verdade com os fatos, estes eram empiristas, mesmo acreditando na intuição sensível, já estavam convencidos de que as reais provas eram provenientes das ciências naturais. ${ }^{83}$

Em meio a tais reflexões a retórica serviu como estudo de tais suposições e seu poder de convencimento diante das opiniões divergentes acerca de um tema específico e como a construção de um argumento afeta na adesão dos indivíduos

\footnotetext{
${ }^{81}$ Idem. p. 134

${ }^{82}$ Idem. p. 137

${ }^{83}$ PERELMAN, Chaïm, OLBRECHTS-TYTECA, Lucie. Tratado da argumentação: a nova retórica. Tradução de Maria Ermantina Galvão G. Pereira, São Paulo: Martins Fontes, 2. reimpressão, 1996. p.2
} 
envolvidos em uma platéia específica, acatando ou não tais afirmações colocadas para julgamento.

Uma teoria da argumentação que permite o uso da razão para guiar a ação e influenciar opiniões, deve admitir a idéia da evidência. A evidência possui o poder de fazer a ligação entre o psicológico e o lógico, além de transitar entre estes dois estágios, a evidência possui a prerrogativa de ser concebida como a força a qual a mente deve ceder e traz um sinal, um indício de verdade em seu conteúdo. As provas seriam a redução da evidência, ou quando esta deixa de ser evidência para se tornar a verdade, sendo aceita pelo auditório. ${ }^{84}$

O "Tratado da Argumentação" segue nos explicando um pouco sobre a Retórica antiga, que se pautava em trabalhar com a arte de persuadir o público, através da palavra, se referindo o discurso, em relação a multidão. Desta maneira, o tratado traz uma análise além desta, pois não delimita a retórica ao discurso oral, direcionado a multidão, mas analisando também outros tipos de discurso.

Durante muito tempo, a palavra "retórica" deixou de ser utilizada e retomada pela necessidade de renovação de significado do termo. Neste sentido Perelman e Tyteca nos explicam:

\footnotetext{
${ }^{84}$ Idem. p.4

${ }^{85}$ Idem. p. 5,6
}

“O raciocínio dialético é considerado paralelo ao raciocínio analítico, mas trata do verossímil em vez de tratar de proposições necessárias. A própria idéia de que a dialética concerne a opiniões, ou seja, a teses às quais se adere com uma intensidade variável, não foi aproveitada. Dir-se-ia que o estatuto do opinável é impessoal e que as opiniões não são relativas aos espíritos que a elas aderem. Em contrapartida, essa idéia de adesão e de espíritos aos quais se dirige um discurso é essencial em todas as teorias antigas da retórica. Nossa aproximação desta última visa enfatizar o fato de que é em função de um auditório que qualquer argumentação se desenvolve. O estudo do opinável dos tópicos poderá, nesse contexto, inserir-se em seu lugar." 
Sendo assim, a retomada do estudo da retórica possibilitou compreender as fontes históricas como discursos proferidos a um auditório que poderia aderir ao que está sendo proferido, ou não, no sentido de que cada auditório enxerga, ou escuta, o discurso, de acordo com uma série de parâmetros que estão contidos dentro do que seria opinável. Portanto, partindo das interpretações dos indivíduos sobre um discurso, podemos compreender o contexto analisado dentro do campo histórico e trazer novas concepções possibilitadas pela retórica.

Mesmo trabalhando com textos escritos procurando trazer compreensões da argumentação que anteriormente era destinada a textos orais, alguns parâmetros seguem utilizados provenientes da retórica tradicional.

\footnotetext{
"O que conservamos da retórica tradicional é a ideia mesma de auditório, que é imediatamente evocada assim que se pensa num discurso. Todo discurso se dirige a um auditório, sendo muito frequente esquecer que se dá o mesmo com todo escrito. Enquanto o discurso é concebido em função direta do auditório, a ausência material de leitores pode levar o escritor a crer que está sozinho no mundo, conquanto, na verdade, seu texto seja sempre condicionado, consciente ou inconscientemente, por aqueles a quem pretende dirigir-se." ${ }^{86}$
}

$\mathrm{O}$ foco com a estrutura do texto argumentativo se faz importante, pois mesmo não se tratando apenas de discursos orais, a organização da retórica tradicional se faz interessante para compreender o funcionamento argumentativo de textos escritos, desta maneira, o texto por razões didáticas, utiliza os termos "orador", "discurso" e "auditório" porém sem se prender no discurso falado. ${ }^{87}$

Também é necessário se atentar para os recursos discursivos utilizados para a adesão dos espíritos, ou seja, a platéia, para o convencimento. Desta maneira, o autor explica que as crenças mais sólidas são aceitas sem provas e nem sequer são explicitadas, porém o recurso de argumentação não pode ser descartado quando as provas são discutidas ou quando não há consenso sobre a sua interpretação.

\footnotetext{
${ }^{86}$ Idem. p.7

${ }^{87}$ Ibidem.
} 
A respeito do estudo de discursos argumentativos, é interessante trazer à tona a reflexão de que os resultados que tais análises podem trazer uma série de explicações, tanto a respeito de que quem está proferindo o discurso, quanto a respeito do receptor do discurso argumentativo e de suas interpretações sobre tal discurso. Desta maneira, o estudo e análise das diferentes formas discursivas devem ser utilizadas de modo que possam abranger interpretações a cerca do compromisso, analisado como texto argumentativo e sem intenções de restringir a interpretação dentro de parâmetros reduzidos em modelos explicativos, assim como já foi de costume em trabalhos com metodologia proveniente de experimentos das ciências dedutivas ou experimentais. ${ }^{88}$

O ponto de partida de um texto argumentativo começa com um raciocínio e o seu desenvolvimento que está intimamente ligado ao acordo que está estabelecido com o auditório em questão, ou, o que o auditório está assimilando e acatando daquele discurso. Da mesma maneira, as escolhas argumentativas, a forma e a organização das ideias, sejam em textos oral ou escritos, também estabelecem conexões acerca da utilização persuasiva do convencimento. ${ }^{89}$

Para que se compreenda os elementos de um texto argumentativo, José Murilo de Carvalho traz a noção da importância do auditório:

"Uma terceira característica da retórica é a importância do auditório.Como ela deve ser eficaz, é necessário que o orador conheça seu público para escolher os argumentos, os estilos, a pronunciação adequados para movê-lo. Auditórios diferentes exigem argumentos e estilos diferentes. Cada auditório terá seus valores, cada época terá seus auditórios. A variação de estilos e argumentos não pode, portanto, ser motivo de crítica ao orador.Ele não estará violando as regras do jogo retórico. A lógica, ao contrário, dispensa totalmente tal preocupação. Ela procura apenas a validade do argumento. A aceitação ou rejeição dos ouvintes não afeta esta validade. Uma última característica é que a retórica permite sempre o compromisso, a modificação parcial da posição dos opositores para se chegar a um ponto de acordo. Isto em lógica é

\footnotetext{
${ }^{88}$ Idem. p. 10

${ }^{89}$ Idem. p. 74
} 
impossível. Neste sentido, a retórica é o campo do debate democrático." 90

Sendo assim, o acordo com o auditório é realizado segundo os objetos de tal acordo, que podem servir como premissas e são classificados em duas categorias, a dos acordos do tipo real, onde são encaixadas premissas lidas como fatos e verdades e na categoria preferivel onde se encontram os valores e as hierarquias. Para tal categorização, deve ser lembrado que o que é considerado real, muda, conforme as convicções pessoais de cada um, mas para a análise argumentativa, o "real" é limitado por o que pretensamente possui validade para o auditório universal e o que é considerado "preferível" se encaixa em pontos de vista determinados que só podem ser definidos de acordo com um auditório particular. ${ }^{91}$

\section{Os critérios do acordo}

Além das categorias do acordo, também existem os tipos de objetos de acordo, o primeiro deles, é a noção de "fato". O que torna alguma ocasião ou alguma informação um fato é o acordo do auditório universal,que não questiona, nem é controverso, sem precisar de justificativa, sem contestação do auditório. ${ }^{92}$ Até este consenso acontecer, não existe a certeza e segurança deste enunciado, pois o acordo sempre será passível de questionamentos por parte daqueles que não aceitam a argumentação dada para tal acordo, apesar de que algum seja considerado fato, isso não traz uma certeza, mas sim um contexto favorável, para que tal acordo fosse defendido facilmente. ${ }^{93}$

Partindo da falta de convencimento da argumentação, os questionamentos que podem colocar em dúvida o status de fato, quando as dúvidas são apresentadas pelo auditório onde o suposto foi apresentado, por pessoas aptas para julgar a argumentação exposta.

\footnotetext{
${ }^{90}$ CARVALHO. Op.Cit. p. 138

${ }^{91}$ PERELMAN, e OLBRECHTS-TYTECA.Op.Cit. p.74

${ }^{92}$ Idem. p.75

${ }^{93}$ Ibidem.
} 
A partir deste ponto, podem ser levantadas dois tipos de questionamentos para que um acontecimento perca o status de fato: quando são levantadas dúvidas no auditório ao qual ele foi apresentado, acrescentando outros membros com qualidade para julgar e que não admitem que se trata de um fato. Os membros encarregados de contestar os fatos apresentados terão o trabalho de tentar desqualificar os argumentos recorrendo para a coerência, demonstrando a incompatibilidade em comparação com outros fatos e demonstrando que trata-se apenas de uma conclusão obtido através da argumentação. Assim, o acontecimento, não será mais considerado fato.

Nada pode determinar se algo é definitivamente um fato ou não, mas através destes mecanismos, torna-se mais plausível que dados sejam aceitos como fatos, com uma credibilidade que não necessita de desconfiança, o fato é uma premissa, sem contestações.

\begin{abstract}
"Aplicamos, ao que se chamam de verdades, tudo o que acabamos de dizer dos fatos. Fala-se geralmente de fatos para designar objetos de acordos precisos, limitados; em contrapartida, designar-se-ão de preferência com o nome de verdades sistemas mais complexos, relativos a ligações entre fatos, que se trate de teorias científicas ou de concepções filosóficas ou religiosas que transcendem a experiência.
\end{abstract}

Se bem que, assim como o sublinha Piaget, os dados psicológicos atualmente conhecidos não permitiam sequer imaginar que possamos atingir fatos isolados, a distinção entre fatos e verdades parece-nos oportuna e legítima para o nosso objeto, por corresponder ao uso habitual da argumentação, que se apóia ora nos fatos, ora nos sistemas de alcance mais geral. Mas não gostaríamos de resolver, de uma vez por todas, o problema filosófico das relações entre fatos e verdades: essas relações caracterizam concepções de auditórios diferentes. Para uns, o fato se opõe a verdade teórica com o contingente o necessário; para outros, como o real ao esquemático. Pode-se também conceber a relação deles de tal forma que o enunciado de um fato seja uma verdade e que toda verdade enuncie um fato."94

Uma terceira categorização aceita pelo auditório é a presunção, que também estão incluídas no auditório universal, mas a aceitação das presunções, devem vim com reforços de outros elementos e devem estar em conformidade com o caso que

\footnotetext{
${ }^{94}$ Idem. p. 77
} 
está sendo discutido. As presunções têm a ver com o que é aceito como normal, sendo assim, segundo Perelman e Tyteca, deve ser levado em consideração que o que é considerado como normal, é aquilo que pode ser imaginado através do raciocínio como uma coisa possível de acontecer, porém, não pode se afirmar de maneira estatística quantas vezes tal fato acontece, sendo assim, a presunção se compara a uma média, o que está na metade, sempre que acordo com um grupo de referência específico. ${ }^{95}$ Além disso, são analisados como objetos do acordo os valores, as hierarquias e os lugares.

O autor nos explica a respeito das presunções utilizadas no acordo como objeto serem confundidas com acordo de fatos:

\footnotetext{
"O acordo baseado na presunção do normal é supostamente válido para o auditório universal da mesma forma que o acordo sobre os fatos demonstrados e as verdades. Por isso, costuma ser difícil distinguir esse acordo do acordo sobre fatos. Os fatos presumidos são, num dado momento, tratados como equivalentes a fatos observados e podem servir, da mesma forma que eles, como premissa para argumentações." 96
}

Quando um auditório aceita ou não as justificativas argumentativas de um fato, significa que este fato colocado deve passar por julgamento de membros autorizados que possuem suas próprias concepções acerca do que acreditam ser real, ou plausível. Nas discussões a respeito da argumentação contra ou a favor de um fato, também conta a posição de prestígio e autoridade dos membros que estão na posição de especialistas. Como exemplo, José Murilo de Carvalho utiliza a jurisprudência, que é utilizada na argumentação jurídica, onde o argumento de autoridade mesmo se houver abusos ou não, as opiniões não podem ser descartadas. ${ }^{97}$

Os valores influenciam nos tipos de argumentações porque os membros recorrem aos princípios como uma ferramenta de convencimento do auditório e também recorrem quando querem justificar as escolhas realizadas anteriormente,

\footnotetext{
${ }^{95}$ Idem. p.80, 81

${ }^{96}$ Idem. p. 83

${ }^{97}$ CARVALHO, Op.Cit. p. 142
} 
para que estas novas sejam consideradas aceitáveis. Devido aos valores servirem de justificativa e de motivo de convencimento, Perelman e Tyteca atribui aos valores uma comparação com os fatos, além de afirmar que os valores não são de adesão do auditório universal. $^{98}$

Tais valores podem ser divididos em valores concretos e valores abstratos e se diferem no sentido de que o concreto é em relação a um determinado grupo, um ente vivo ou um objeto particular, além disso, o valor do concreto, está ligado a uma maior credibilidade do que o valor abstrato. Em contrapartida a esta concepção, existem certos valores não podem ser encaixados como concretos, como comportamentos e qualidades. ${ }^{99}$

$\mathrm{Na}$ argumentação, são utilizados tantos os valores concretos como os valores abstratos, dependendo do que se considera necessário no momento e é interessante ressaltar que o que pode ser considerado valor concreto em um grupo específico, para outro grupo, pode ser visto como um valor abstrato. ${ }^{100}$

"Estar de acordo acerca de um valor é admitir que um objeto, um ser ou um ideal deve exercer sobre a ação e as disposições à ação uma influência determinada, que se pode alegar numa argumentação, sem se considerar, porém, valores, como objetos de acordo que possibilitam uma comunhão sobre modos particulares de agir, é vinculada à enunciados concernentes ao que chamamos de valores, na medida em que não eram tratados como verdades indiscutíveis, estavam englobados, com toda espécie de afirmações verossímeis, no grupo diferenciado das opiniơes."

Mais um artifício da argumentação, é a hierarquia, que traz a noção de superioridade entre seres ou situações, onde tal ordem de importância fica na maioria das vezes, subentendida.

“As hierarquias de valores são, decerto, mais importantes do ponto de vista da estrutura de uma argumentação do que os próprios valores. Com efeito, a maior parte destes são comuns a um grande número de

\footnotetext{
${ }^{98}$ PERELMAN, e OLBRECHTS-TYTECA. p.84

${ }^{99}$ Idem. p. 87

${ }^{100}$ Idem. p. 88

${ }^{101}$ Idem. p.84
} 
auditórios. O que caracteriza cada auditório é menos os valores que admite do que o modo como os hierarquiza.

Os valores, mesmo se admitidos por muitos auditórios particulares, o são com maior ou menor força. A intensidade da adesão a um valor, em comparação com a intensidade com a qual se adere a outro, determina entre esses valores uma hierarquia que se deve levar em conta. Quando essa intensidade não é conhecida com precisão suficiente, o orador tem, por assim dizer, liberdade na utilização de cada um dos valores, sem precisar justificar necessariamente a preferência que concede a um deles, uma vez que não se trata de subverter uma hierarquia admitida. Mas esse caso é relativamente raro. Quase sempre, não só os valores gozam de uma adesão de intensidade diferente, mas além disso, são admitidos os princípios que permitem hierarquizá-los. Este é um dos pontos para os quais muitos filósofos que tratam dos valores descuraram de chamar atenção. Porque estudaram os valores de certo modo neles próprios, independentemente de sua utilização argumentativa prática, os filósofos insistiram, com toda razão, na convergência dos valores, descurando o mais da vezes de sua hierarquização, da solução de conflitos que os opõem." 102

O sentido da hierarquização é que eles são colocados em uma ordem de importância, pois se faz necessário uma escolha entre valores concretos e abstratos, portanto, é utilizada quando é necessário colocar um argumento sobre o outro em um debate, fazendo com que um dos valores aceito seja sacrificado em detrimento do outro, mais valorizado hierarquicamente. ${ }^{103}$

Por último, estão os lugares, que segundo o Tratado da Argumentação, são definidos como premissas de ordem generalizada ou por tratados consolidados ao raciocínio dialético. ${ }^{104}$

\section{Seleção de dados}

É muito importante ter a consciência de que para a realização de um texto que busca argumentar e convencer, o orador dispõe de um infinidade de dados que podem ser utilizados de muitas maneiras diferentes. Sendo assim, torna-se muito importante o exame da escolha dos dados utilizados, o ponto de partida e a

\footnotetext{
${ }^{102}$ Idem. p.92

${ }^{103}$ Idem. p.94

${ }^{104}$ Ibidem.
} 
adaptação destes dados nos objetivos para os quais eles foram escolhidos. ${ }^{105}$ Tais escolhas podem mudar completamente a maneira da qual o auditório irá receber a mensagem, como vai interpretar e julgar a mensagem transmitida.

\section{Escolha dos dados e sua adaptação}

Devido ao grande número de acordos, que podem se apresentar dos mais diferentes modos para que o orador possa se utilizar para a argumentação, torna-se muito relevante a análise a respeito de como essa escolha é realizada. Além da escolha, também deve-se atentar para a adaptação dos acordos argumentativos escolhidos pelo orador. Por outro lado, a escolha argumentativa de um texto, mostra alguns elementos de convencimento que estão sendo utilizados para o auditório e deixa de elucidar uma série de elementos que não interessam para o convencimento daquele público específico, logo também podem trazer ao historiador, outros esclarecimentos que não estão expostos no textos. ${ }^{106}$

A respeito da escolha dos dados, devemos notar o fator da presença, no sentido de que a aquilo que não é mostrado na argumentação, ou seja, aquilo que não está presente, também têm influência na argumentação, ajudando a determinar o julgamento do auditório a respeito de determinado tema. Desta maneira, não basta que algo exista para se possa levar em consideração plenamente, quando tratamos de argumentação, pois, segundo o autor, a presença atinge uma importância na sensibilidade dos indivíduos diferente do que se tal fator tivesse sido omitido. ${ }^{107}$ Compreendendo a presença como um fator de seleção de elementos, pode-se admitir que a argumentação é seletiva, portanto é tendenciosa para que seja convincente para o auditório universal. Os elementos são escolhidos para uma argumentação específica, assim como sua técnica de apresentação, no sentido de que são organizados para que sua forma se mescle com as questões de fundo, para que assim

\footnotetext{
${ }^{105}$ Idem. p. 131

${ }^{106}$ Idem. p. 131

${ }^{107}$ Idem. p. 132
} 
seja perceptível a presença. ${ }^{108}$ Pelo outro lado, a falta de presença intencional, ou não, pode modificar a compreensão e o sentido do discurso.

A análise da argumentação não pode levar em consideração apenas a seleção dos dados, mas também, a maneira como estes dados são interpretados e o significado escolhido para a atribuição destes dados, que podem ser de inúmeras formas.

\begin{abstract}
"A infinita complexidade das interpretações, sua mobilidade e sua interação explicam suficientemente a impossibilidade de reduzir todos os enunciados a proposições cuja probabilidade numérica possa ser determinada. Mesmo que um aumento de nossos conhecimentos permita especificar essas probabilidades, isso só ocorre se permanecermos no âmbito de uma interpretação determinada. Convencionalmente nada se opõe a isso, mas também nada poderá impedir que uma nova interpretação seja aventada ou sugerida implicitamente. As possibilidades de interpretação parecem inesgotáveis." ${ }^{109}$
\end{abstract}

As diferentes interpretações e as suas diferentes interações mostram que não existe a possibilidade de numerar a quantidade de possibilidades possíveis de situações de interação argumentativa. Devemos atentar para a observação de que, ao se analisar um texto argumentativo, se o fato oferecer preferência de interpretação ou aceitar apenas aceitar uma única interpretação como a correta ou verdadeira, isto demonstra uma tendência de crenças e de entendimentos a respeito do tema que está sendo discutido ou até mesmo o conjunto de valores dos quais se acreditam para construir a argumentação. ${ }^{110}$

Além da interpretação dos dados, também deve ser levada em consideração a disposição e organização destes mesmos dados, no texto argumentativo, pois tais fatores também influenciam na argumentação e na interpretação do texto. A interpretação de um texto ou discurso deve conter as intenções do seu autor, porém, não podemos esquecer que as impressões a respeito de um discurso também estarão

\footnotetext{
${ }^{108}$ Idem. p. 136

${ }^{109}$ Idem. p. 138

${ }^{110}$ Ibidem.
} 
sendo vistas através do olhar de quem fez tal interpretação. Na interpretação deve-se também procurar com atenção, dados que não estão sendo falados explicitamente, pois a clareza de um texto se relaciona com as diferentes maneiras das quais este mesmo texto poderá ser interpretado. Portanto, um texto não pode ser considerado totalmente claro, já que a interpretação também pode se modificar de acordo com contextos particulares que vão enxergar nuances diferentes. ${ }^{111}$

Assim como já enfatizado anteriormente, o resgate dos estudos da retórica se mostrou muito importante para auxiliar o trabalho do historiador, trazendo diferentes elementos a respeito da linguagem utilizada no texto, do orador e do ouvinte, ou leitor. ${ }^{112} \mathrm{~A}$ análise retórica utilizada como instrumento para a compreensão de fontes históricas deve ser realizada sem a restrição apenas nos aspectos citados acima como os objetos do discurso, mas sim procurando no texto estudado,resquícios do que pode trazer uma visão diferente a respeito do tema analisado, procurando na sua forma de escrita padrões do contexto analisado e possíveis desvios de escrita, figuras de linguagem, instrumentos de persuasão, entre outros aspectos que serão dados pela própria fonte histórica.

\section{Análise retórica do Compromisso}

A retórica como auxiliar da disciplina histórica pode trazer maiores esclarecimentos a respeito da Irmandade da Nossa Senhora do Rosário dos Pretos da Vila de Goiana, através da análise do seu compromisso, procurando na escrita do documento, vestígios de como os irmãos se relacionavam em relação as autoridades da coroa portuguesa e de como se relacionavam entre eles mesmos.

Primeiramente, é necessário atentar para o fato de que o compromisso da irmandade era um documento necessário para que a coroa portuguesa permitisse o funcionamento da irmandade, portanto, ao examinar o documento, devemos ter em mente que o compromisso deveria atender a uma série de exigências para que este fosse aprovado e a irmandade pudesse funcionar.

\footnotetext{
${ }^{111}$ Idem. p. 143

${ }^{112}$ CARVALHO, Op.Cit. p.136
} 
Para compreender o discurso contido no compromisso dos Irmãos de Goiana, se faz necessário salientar que o estatuto dos irmãos deveria estar de acordo com a postura das autoridades da Coroa portuguesa, que adotou na segunda metade do Século XVIII, uma atitude intervencionista e centralizadora. Sendo assim, a ênfase na organização e na ordem contida no discurso dos compromissos, se repetindo também no compromisso da Irmandade dos pretos de Goiana, poderiam ser uma maneira de buscar uma certa autonomia das autoridades, já que demonstravam neste documento que tinham empenho em manter a ordem exigida. ${ }^{113}$

Outro ponto bastante importante na análise dos compromissos de irmandades negras no período colonial, é que estas instituições produziam sua documentação de acordo com os outros compromissos de irmandades, sendo assim, o discurso contido no documento já está restringido de alguma maneira pela forma, mas é inevitável que no caso analisado, apareçam traços específicos da organização dos irmãos de Goiana.Deve ser levado em consideração que ao submeter um compromisso para a aprovação das autoridades eclesiásticas da colônia, o documento traz em seu discurso traços específicos que serão explorados através da análise retórica.

Maristela Simão define os compromissos de irmandades religiosas como:

"Frutos de uma sociedade em grande parte
iletrada, onde a comunicação muitas vezes não
passava pelos canais oficiais e não deixava rastros
escritos, os pedidos de aprovação obrigavam estas
associações a passar pelos canais burocráticos,
através dos quais nos chegam hoje grande parte das
informações que podemos possuir sobre o assunto.
Estes pedidos de aprovação são também
bastante importantes para o estudo da atuação, tanto
da Coroa quantos dos Bispos, sobre estas
associações. Cumpre sempre ressaltar que a
constituição formal de uma irmandade só se
realizava em um momento posterior a sua fundação,
não no momento de sua edificação. Normalmente
realizado a pedido de uma mesa diretora, seus

${ }^{113}$ SOUZA, Fernando Prestes de. LIMA, Priscila de. "Que haja paz e quietação": controle social e irmandades negras na América Portuguesa. Século XVIII. Revista Ágora, Vitória, n.11, 2010, p.1-22 .p.5 
membros realizavam os esforços necessários para dar início a essa oficialização." ${ }^{114}$

Assim como ressaltado pela autora, os compromissos podem mostrar aos pesquisadores bastante sobre como os bispos e autoridades tratavam os trâmites legais a respeito das irmandades negras, mas também nos mostra como os irmãos lidam com todas estas exigências das autoridades coloniais. Neste sentido, pretende-se utilizar a chave da retórica como uma ferramenta para analisar tais detalhes do discurso escrito pelos irmãos.

Já no primeiro capítulo, o compromisso nos traz em suas linhas, a necessidade dos irmãos agirem com zelo, fervor e humildade, além de servirem com fé a deus e a sua santíssima mãe. Logo a frente, no capítulo V do compromisso, estão descritos no compromisso os cargos os quais os irmãos iam ocupar e além de definir estes cargos, o texto salienta que as pessoas para tais cargos deverão ser escolhidas através de eleições e além disso, devem ser ocupados por pessoas zelosas, tementes a deus, de boa vida e consciência e depois, se cumprirem tais requisitos e forem zelosos ao longo de um ano de duração do cargo, poderiam ter seu posto estendido em até dois anos. O cargo de procurador, especificamente, se fosse realizado de maneira zelosa, poderia ser estendido até o quanto a irmandade lhe concedesse. Outros detalhes interessantes do discurso se mostram quando este mesmo capítulo do compromisso restringe a origem dos irmãos que pleiteavam o cargo de mordomo:

\begin{abstract}
"Haverá nesta Santa Irmandade hum Juiz da Mesa, hum escrivão, hum Procurador, hum tesoureiro, doze mordomos a saber seis nacturales do Brazil, e seis do gentio de Angola, ou Costa de Leste: Hum Andador, hum Sacristão, que todos estes serão eleitos por votos, e se procurará para esta eleição pessoas zelozas, tementes a Deos, de boa vida e san conciência e nunca em casa hum dos deferidos cargos poderão servir os Irmãos."115
\end{abstract}

\footnotetext{
${ }^{114}$ SIMÃO, Maristela dos Santos. As irmandades da Nossa Senhora do Rosário e os Africanos no Brasil do Século XVIII. Faculdade de Letras, Universidade de Lisboa, 2010. p.57

${ }^{115}$ Compromisso da Irmandade de nossa Senhora do Rosário dos homens Pretos da Villa de Goyanna (1783) - AHU_ACL_CU-Cod. 1717 p..252
} 
$\mathrm{O}$ trecho do documento apresentado na passagem acima, mostra como o discurso da Irmandade se faz de maneira restritiva, explicitando que a irmandade possuía critérios específicos ao decidir quais pessoas poderiam ou não fazer parte da organização, além de especificar também quais pessoas deveriam ser escolhidas para cargos específicos dentro da organização. É importante ressaltar que a escolha de irmãos através do critério da origem, também se dá no capítulo IX, quando o compromisso versa sobre a coroação do Rei e da Rainha de Congos, onde é especificado que além de ocuparem tal posto por merecimento, deveriam também ser da nação de Angola e preferencialmente livres. Em tal cargo, seriam aceitas pessoas em cativeiro, caso não houvessem libertos suficientes para ocupar tais cargos.

Tais restrições descritas no compromisso ou quando o documento especifica os critérios para assumir os cargos da irmandade e durante quanto tempo os irmãos ocupariam tais cargos de acordo com o seu comportamento, demonstram a importância dos valores que os irmãos tomavam como princípios necessários para a confraria. É interessante ressaltar que as autoridades eclesiásticas e a Irmandade partilhavam em alguns valores em comum, como as obrigações, o zelo, a devoção e fé e o prestígio, além disso, partilhavam valores em relação a punição dos irmãos que não se comportassem da maneira esperada pela organização, o que demonstra um êxito para a igreja católica, no sentido de que a adesão dos pretos libertos ou não, na irmandade também era um instrumento de colonização, como nos explica Caio Boschi:

\footnotetext{
"A expansão do Cristianismo, entre os portugueses, integrou os mecanismos e o processo de colonização. Nessa medida, a Coroa era quem estabelecia as diretrizes da ação da Igreja, transformando a evangelização num assunto de Estado, isto é, a utilização da Igreja como um instrumento de conquista." 116
}

116 BOSCHI, Caio. Os Leigos e o Poder (Irmandades Leigas e Política Colonizadora em Minas Gerais).Editora Atica, 1986 - p.61 
A restrição em relação a origem dos irmãos que ocupariam os cargos de mordomos, também traz a tona à noção da necessidade de pertencimento na Irmandade, no sentido de precisar para tal cargo, que os irmãos fossem nascidos tanto nas terras da América Portuguesa, quanto no Gentio de Angola ou na Costa Leste. Fundamentada na restrição dos cargos a serem ocupados pelos irmãos, pode se compreender a construção da identificação destas pessoas baseadas nas dinâmicas da sociedade colonial. Segundo João José Reis:

“ As identidades étnicas encontraram um solo fértil no Brasil colonial. A sociedade formada na colônia escravocrata estava estruturada em moldes corporativistas que refletiam diferenças sociais, raciais e nacionais. As irmandades são um exemplo disso. Muitas fizeram as vezes de corporações profissionais típicas do antigo regime. Algumas poucas abrigavam a nata da sociedade, a "nobreza" da Colônia, os senhores de engenho, altos magistrados, grandes negociantes. Mas o principal critério de identidade dessas organizações foi a cor da pele em combinação com a nacionalidade. Assim, havia irmandades de brancos, de mulatos e de pretos. As de brancos podiam ser de portugueses ou de brasileiros. As de pretos se subdividiam nas de crioulos e africanos. Estas podiam se fracionar ainda de acordo com as etnias de origem _ ou, como se dizia na época, as "nações" _, havendo as de angolanos, benguelas, jejes, nagôs etc.

A distinção étnico-nacional constituía a lógica de estruturação social das confrarias no Brasil. Nesse ponto os africanos pouco inovaram, apenas se adaptaram ao ambiente. O surpreendente é constatar quão bem eles se adaptaram e, a partir daí, criaram micro estruturas de poder, conceberam estratégias de alianças, estabeleceram regras de sociabilidade, abriram canais de negociação e ativaram formas de resistência."117

A categorização dos irmãos ou até mesmo sua aceitação dentro da Irmandade ou não, explicitadas no documento, demonstram a importância de informar ao auditório tais restrições, ao mesmo tempo, traz uma importante observação. Primeiro, devemos lembrar que ao ser tratar de uma instituição religiosa de brancos colonizadores, que se interessavam na adesão dos escravos e negros libertos na irmandades como mais uma forma de controle político, social e religioso em suas

\footnotetext{
${ }^{117}$ REIS. Identidade... Op.Cit. p.5
} 
vidas. Ao mesmo tempo, o compromisso demonstra em seu discurso que os irmãos tinham a intenção de cumprir rigidamente as regras colocadas pelo estatuto. Uma dessas situações é quando os irmãos descrevem sobre o desejo de custear a festa:

"Avendo pessoa alguã de qualquer condição que seja
querendo servir de Juiz de nossa Senhora do
Rosário, ou de algum dos mais Santos erectos na
nossa Santa Caza festejando dezenteressadamente a
sua custa, cujo beneficio lhe agradecera muito a
Irmandade, e havendo Procissão, nella nunca levará
as insignias sendo os nossos Irmãos pretos e somente
se concede do Juiz actual e os da Mesa obsequiarao
de voto. Juiz entregando lhe a vara de prata para
com ellas prezidir atras do Pálio em remuneração do
que asima dito fica."

Como fica explicitado na passagem acima, a possibilidade de algum irmão bancar a festa por vontade própria, sem ser obrigação imposta pela irmandade. Tal trecho, demonstra que os irmãos praticavam ações de iniciativa própria e autonomia financeira, demonstrando sua fé e devoção a Nossa Senhora do Rosário. Mesmo com todas estas considerações, o fato de poder ser explicitado no compromisso tais restrições nos mostram uma certa permissividade por parte das autoridades, já que tais descrições demonstram traços de identificação entre os irmãos, se tornando um espaço de convivência social e criação de laços, o que em alguma medida, poderia ameaçar a ordem do sistema escravocrata vigente.

É interessante ressaltar que ao longo do compromisso, estão presentes alguns termos no discurso que a todo tempo, remetem a ordem e disciplina dos irmãos, sempre afirmando o quanto o rigor era importante para a instituição. No capítulo VI, que dita sobre as formalidades da eleição do cargo de Capelão da Irmandade, se faz necessário afirmar que os irmãos candidatos ao cargo serão escolhidos de acordo com aquele tem que a "mais santa vida com a perfeição de pregador e confessor prudente e exemplar" ${ }^{119}$, afirmando novamente a necessidade da disciplina.

\footnotetext{
${ }^{118}$ Compromisso da Irmandade de nossa Senhora do Rosário dos homens Pretos da Villa de Goyanna (1783) - AHU_ACL_CU-Cod. 1717 p.271

${ }^{119}$ Idem. p. $25 \overline{4}$
} 
Mais a frente, no capítulo XXI, que versa sobre as obrigações gerais dos irmãos, está especificado que, o não cumprimento das funções designadas a cada integrante ou o cumprimento de maneira insatisfatória, resulta em um julgamento, onde o Juiz da mesa possa decidir qual seria a quantia a ser paga pelos irmãos, sendo admoestado podendo ser banido da irmandade. Porém, se tal irmão demonstrar arrependimento e procurar a Santa Casa pedindo perdão, este poderia ser readmitido. No mesmo capítulo do compromisso, ainda é alertado uma ressalva na readmissão de irmãos: "Salvo constante verdadeiramente Juiz de mesa e mais irmãos dela ser o dito irmão de sua natureza perturbador da paz e solicitador de desordens para inquietação da Irmandade, então nesse caso nunca mais será admitido."

No capítulo XXVII da Irmandade da Nossa Senhora do Rosário dos pretos de Goiana, é especificada a punição que poderia ser aplicada ao irmão que não efetuasse o pagamento de esmolas, sofrendo o risco de ser riscado, ou seja, expulso da Irmandade. Ao longo de todo o compromisso fica ressaltado de que os irmãos deveriam seguir a conduta imposta para atender aos anseios das autoridades e dos próprios irmão. Se não sendo cumpridas tais exigências, os irmãos sofreriam variadas punições, cada uma de acordo com a infração cometida, podendo varias vezes, chegar a ser expulso da Irmandade.

Neste compromisso, assim como em vários outros compromissos de Irmandades de pretos e pardos da América portuguesa, a escrita se assemelha com os compromissos das Irmandades de brancos, o que chama atenção devido a uma série questões. Partindo desta indagação, Maristela Simão nos atenta para o fato de que os compromissos de Irmandade parecem seguir uma forma específica:

\footnotetext{
"De forma geral, no entanto, os compromissos parecem ter tido uma base única, desde a fundação da primeira irmandade e daí em diante, apenas acrescentando, retirando ou mesmo reescrevendo capítulos de acordo com suas necessidades, adaptando-o à realidade de cada Irmandade. Como já nos referimos acima, para ser aprovado por todas as instâncias, e principalmente pela Coroa, nem sempre se mantinha o texto original elaborado pelos irmãos nas provisões, sendo recorrente para a aprovação a
} 
modificação, a pedido da Coroa, de alguns pontos do Compromisso."120

Maristela Simões, afirma que de acordo com seu estudo de comparação do compromisso da Irmandade de Nossa Senhora do Rosário dos Pretos dos Homens Pretos da Freguesia de São Miguel do Ipojucá, utilizado como base, com outros compromissos que seguem uma base estrutural, mudando de acordo com as especificidades de cada Irmandade. ${ }^{121}$

Como várias partes do discurso do compromisso são utilizadas a partir do modelo de outros compromissos, a margem para analisar o discurso específico da Irmandade do Rosário dos Pretos de Goiana se torna menor. Ao mesmo tempo, torna mais visível a necessidade da Irmandade de precisar do aval das autoridades para funcionar, mesmo que tal compromisso possa não falar a respeito de todas as práticas entre os irmãos.

Tais práticas contidas no discurso a respeito da fé e do zelo dentro dos papéis dos irmãos de Goiana são repetidas ao longo de todo o compromisso e trazem noções a respeito do auditório em questão, seus objetos de acordo preferíveis, ou seja, de acordo com os princípios e hierarquias dos avaliadores do compromisso. Pelo que parece, a Coroa Portuguesa exigia das organizações católicas, como as irmandades, um comportamento exemplar de acordo com suas normas onde os indivíduos deveriam ter uma boa conduta, além de zelo e demonstração de fé. Além disso, os próprios irmãos demonstram no compromisso, que tinham os seus próprios mecanismos de controlar o comportamento e demonstram sua devoção.

Além da necessidade de zelo e boa conduta na Irmandade, também se faz interessante ressaltar o teor de desconfiança presente ao longo do compromisso. $\mathrm{Na}$ descrição do cargo de Juiz de Mesa, é descrito que o indivíduo eleito não poderá guardar nenhum dinheiro que seja destinado a irmandade, sendo punido caso tal fato

\footnotetext{
${ }^{120}$ SIMÃO. Op.Cit. p.78

${ }^{121}$ SIMÃO.Op.Cit. p.79
} 
aconteça. ${ }^{122}$ Logo a frente, na descrição das obrigações do cargo de escrivão, estão colocadas as funções de fechar os livros e outros papéis da irmandade, fechar contas, além de não poder isentar algum irmão de suas dívidas sem a presença dos demais irmãos da mesa. É destacado que o escrivão deverá entregar os livros no final do ano de seu governo, para que desta maneira, sejam evitadas as suspeitas a respeito do irmão escrivão. ${ }^{123}$

Outro exemplo da desconfiança no discurso do compromisso, está no capítulo XXVI, onde são colocadas várias descrições de obrigações e suas punições, caso tais obrigações não sejam cumpridas ou sejam cumpridas de maneira incorreta. Entre elas, estão o pagamento de esmola, especificando que aquele que não pagar, mesmo tendo posse para pagar, será riscado da irmandade. ${ }^{124}$

Tal desconfiança, explicitada por meio da necessidade de se evitar suspeitas, nos mostra um pouco a respeito do auditório em questão. O compromisso da Irmandade tinha como conteúdo o regulamento da Irmandade, ditado sobre suas regras de organização e de conduta, porém, o fato de sempre trazer em seu discurso, a desconfiança e o destaque para as punições caso os irmãos descumprissem o que está contido como padrão no compromisso, nos mostra um pouco além de apenas um documento para ditar as regras da irmandade. Além de ditar sobre o regimento, o compromisso é colocado como um documento sobre o que as autoridades eclesiásticas acham necessário e essencial para a irmandade. Ao mesmo tempo, mostram que os irmãos se importavam bastante com as regras que estavam contidas no documento. Um questionamento interessante em relação ao cumprimento das regras existe, já que as punições descritas com tanto afinco pode ser um sinal de que alguns irmãos não fossem tão disciplinados quanto a instituição exigia. Afinal, se estes irmãos agissem apenas de acordo com as regras do compromisso, não seriam necessários tantos parágrafos dedicados a descrever as punições possíveis, também não seria necessário a cada trecho, reafirmar a necessidade de boa conduta e fé por parte dos Irmãos.

\footnotetext{
${ }^{122}$ Compromisso da Irmandade de nossa Senhora do Rosário dos homens Pretos da Villa de Goyanna (1783) - AHU_ACL_CU-Cod. 1717.p.259

123 Idem. p. 260

${ }^{124}$ Idem. p.267
} 
No capítulo XXVIII que trata a respeito dos irmãos que estão inimizados, é descrito que no caso de inimizades, os irmãos deveriam informar ao Reverendo Capelão para que este chame os outros Irmãos e perante a ao Juiz e a Mesa, resolvam suas questões, para que não haja mais inimizade e que não existam rumores ou boatos sobre tais conflitos entre os outros irmãos. Tal reconciliação era necessária pois a inimizade entre irmãos seria a origem de outros males e não eram do agrado de deus, segundo o documento, se ainda sim, estes continuassem a desavença, o Reverendo Capelão tinha a função de penitenciar tais irmãos e se caso esta penitência não fosse cumprida, o procedimento era a expulsão da irmandade. ${ }^{125}$

Ao longo de todo o Compromisso podemos notar também a construção em relação a presença ou a falta de presença. Como já dito anteriormente, provavelmente o compromisso foi escrito baseado em outros compromissos de irmandade. Desta maneira, pela forma como o documento foi redigido, percebe-se a intenção de escrever exatamente o que as autoridades da Coroa Portuguesa gostariam de ler para estar de acordo com o documento e assim validar o funcionamento da irmandade e demonstrar o empenho dos irmãos com a devoção e as atividades da confraria. Problemas, conflitos, desavenças entre os irmãos, discordâncias, entre outros detalhes não são colocados no compromisso, o que pode trazer duas reflexões: A de que a Irmandade dos homens pretos de Goiana não tinha nenhum tipo de conflito ou discordância quando estavam redigindo o compromisso. Ou a reflexão de que o compromisso omite tais conflitos que poderiam existir para, desta maneira, persuadir convencendo o auditório em questão, utilizando assim, a falta da presença na retórica da sua escrita para que seu discurso seja aceito mais facilmente.

A presença pode ser deduzida por meio de presunções subentendidas no texto e não precisam necessariamente escritas de maneira explícita no texto, com isso,o uso ou não da presença representou uma boa maneira dos irmãos de se adaptarem as regras das autoridades e praticarem suas próprias regras.Ao apresentarem seus capítulos sobre a boa conduta e fé dos irmãos ou sobre a garantia de punição no caso

\footnotetext{
${ }^{125}$ Idem. p. 269
} 
de desobediência das regras impostas pelo regimento, estão demonstrando ao seu auditório bons argumentos para que as autoridades sejam convencidas e a irmandade possa funcionar.

Os mesmos capítulos do compromisso que dissertam sobre as boas maneiras e fé que deveriam ser praticadas pelos irmãos são os mesmos que têm o poder de atentar o leitor do da fonte para tais conflitos no interior da irmandade. Ao se analisar a construção do texto visando seu poder de convencimento, podemos nos perguntar por que tais elementos estão colocados no texto em detrimento de outros, porque os irmãos escolheram abordar tais aspectos e reafirmar a fé e a conduta cristã, já que a própria irmandade tem como objetivo principal o culto e devoção a Nossa Senhora do Rosário dos Pretos, além de executar outras funções importantes entre seus irmãos.

O medo é um elemento constante ao longo do compromisso e utilizado para o controle dos irmãos, no sentido de que fazer parte da Irmandade era algo importante para vida espiritual e para as relações sociais destes indivíduos, assim, o não cumprimento das regras estipuladas no compromisso, resultavam na expulsão da confraria. Assim sendo, tanto os irmãos, quanto as autoridades eclesiásticas sabiam da importância da Irmandade, mantendo o controle dos irmãos através da ameaça de expulsão.

Tais afirmações a respeito da fé e conduta dos irmãos e ameaças supondo o descumprimento de tais regras, pode representar um argumento de convencimento do compromisso para as autoridades e não necessariamente a rigidez da conduta dentro da irmandade. Outra possibilidade é que os irmãos não teriam como prática comum tal disciplina, sendo necessário a afirmação de tal conduta no compromisso para conseguir o comprometimento dos irmãos para o cumprimento das regras impostas.

Através de todo o compromisso pode-se enxergar que os irmãos tinham sua própria concepção acerca dos princípios e valores que eram necessários para integrar o grupo e para conseguir a aprovação da irmandade, ao mesmo tempo em que tinham seus próprios princípios e valores a serem seguidos dentro da Irmandade. 
A retórica se mostrou uma ferramenta metodológica muito importante para a análise do Compromisso, pois permitiu analisar nuances que não seriam explorados caso o documento não fosse visto como um instrumento de convencimento da Coroa Portuguesa. A retórica aliada ao contexto histórico da fonte possibilita compreender como funcionavam os mecanismos de aceitação tanto da Irmandade pela Coroa Portuguesa, quanto a aceitação interna entre os irmãos. 


\section{Capítulo 4 - A Análise contextualista}

Trabalhando com diversas metodologias para trazer uma análise heterogênea para os compromissos de irmandades negras na América Lusa, pode-se trazer à tona ferramentas de outras áreas do conhecimento que habitualmente, não são utilizadas para tais fins. Sendo assim, este capítulo traz reflexões acerca de uma análise contextualista das fontes históricas, mais especificamente, do compromisso dos pretos de Goiana.

Ao analisarmos uma fonte histórica como um texto que pode ser investigado através de várias óticas, podemos encontrar, em cada uma destas visões,diferentes abordagens para uma única fonte histórica. Neste sentido, este capítulo tem como propósito, analisar o compromisso da Irmandade da Nossa Senhora do Rosário dos Homens Pretos de Goiana se servindo de uma metodologia contextualista para assim, como nos outros capítulos, procurar compreender melhor o compromisso como uma fonte histórica e o que este documento pode nos dizer a respeito da organização daquelas pessoas e seu cotidiano dentro da irmandade.

Fernando Nicolazzi, em "Um estilo de História - a viagem, a memória e o ensaio: sobre Casa Grande e senzala e a representação do passado" aborda o estilo e a intencionalidade como ferramentas importantes de um texto para elaborar perguntas e servirem de ponto inicial para as possibilidades de um trabalho. ${ }^{126}$ Partindo da análise contextualista utilizada na disciplina histórica, John Pocock, traz em sua obra "Political Thought and History", uma série de questões sobre teoria e metodologia da História.

Primeiramente, Pocock nos explica sobre a tradição, o papel do historiador e como estes aspectos afetam o trabalho ou podem influenciar na interpretação das fontes históricas. No estudo da História, o pensamento político deve ser examinado no sentido de procurar enxergar os objetos que se tornam o foco

\footnotetext{
${ }^{126}$ NICOLAZZI, Fernando. Um estilo de História: a viagem, a memória, o ensaio: sobre Casa-grande \& senzala e a representação do passado.São Paulo: Ed. Unesp, 2011. 484p. p.25
} 
do estudo. Esta preocupação é um ponto importante abordado por Pocock, pois quando o historiador aborda a fonte histórica utilizando a tradição, ele está trabalhando de acordo com as suas posições intelectuais e concepções que não são deixadas de lado no momento da análise da fonte, pois não tem como estes elementos existirem separadamente. Mesmo sabendo destes nuances inevitáveis, deve-se saber distinguir os vários posicionamentos possíveis que as tradições podem impor. Essa característica da relação com a tradição é denominada por Pocock de "História do pensamento político". ${ }^{127}$

A "tradition of behaviour" ou tradição do comportamento, é qualificada pelo autor como um sistema complexo de maneiras de comportamento que sofrem interferências do passado social. John Pocock concebe o pensamento político como um aspecto do comportamento social, a partir da maneira que as pessoas se comportam, de como lidam entre si e com suas instituições ou como isso é regulado pela intelectualidade. Na política, assim como em outras formas de pensamento social, não é possível isolar os pensamentos ou as funções de abstração uma da outra. Estes pontos de abstração e o nível dos pensamentos mudam dinamicamente entre a teoria e a prática. Desta maneira, um pedaço, um fragmento de um pensamento pode ser analisado como uma intenção de persuadir o leitor politicamente e como um incidente de interpretação, uma das maneiras de se compreender aquela mensagem que está sendo passada. ${ }^{128}$

Segundo Nicolazzi, Pocock analisa a relação entre a dimensão da intencionalidade e a dimensão do contexto, já que para ele a concepção de mundo é construída segundo o processo histórico, onde tudo é compreensível devido as linguagens históricas construídas, assim sendo, a interpretação dos discursos e de suas intenções serão de acordo com o contexto dos indivíduos analisados. Assim, toda a intenção está contida no espaço da linguagem e está relacionada com as ações

\footnotetext{
${ }^{127}$ POCOCK, John. Political Thought and History - Essays on Theory and Method.Cambridge University Press, 2009. p.4

${ }^{128}$ Idem. p.5
} 
do autor na hora da escrita e no caso específico aqui estudado, relacionada com condições de produção da fonte histórica. ${ }^{129}$

Ao se tratar da história do pensamento político de um período específico, é realizado por parte do pesquisador, um levantamento do número de pensadores que desenvolveram suas ideias políticas para atender a maior quantidade de problemas com diferentes abstrações. Desta maneira, este material é reunido para a construção de uma história coerente em relação isso. Assim, a tendência de estudar cada pensador em um alto nível de abstração é para que sejam formuladas certas afirmações gerais em relação as interpretações escolhidas. Pocock explica que a tradição se faz no objeto de estudo que foi condensado em uma única narrativa, tomando o lugar de um alto nível de abstração. Assim, as respostas dependem do critério adotado pelo próprio historiador para a realização de perguntas, sendo que para dosar tais perguntas, faz sentido perguntar se as abstrações condizem com as experiências da realidade. ${ }^{130}$

Partindo do pressuposto de que o pensamento político configura "uma abstração da tradição", tal abstração deve ser enxergada através de diversas lentes, ou seja, por meio de várias generalidades teóricas, por isso, para o autor, o objetivo é de que o historiador possa verificar se o pensamento político realmente substituiu uma abstração que anteriormente era a explicação de tal pensamento. Assim sendo, o nível de abstração é determinado pela necessidade que existe de encontrarmos uma explicação racional para o pensamento que está sendo estudado.

Com base nestas compreensões a respeito das abstrações compreendidas como pensamento político, Pocock afirma que a história não foi capaz de encontrar um método ideal onde estes vários níveis de interpretação pudessem ser compreendidos, além de existirem diversos níveis de coerência racional que podem ser explorados. Por conta da impressão de que o pensamento político, em qualquer um dos seus níveis de abstração, é um modo de discussão de certas experiências sociais. Desta maneira, o autor nos coloca que se faz extremamente necessária a

\footnotetext{
${ }^{129}$ NICOLAZZI. Op.Cit. p.28

${ }^{130}$ POCOCK. Op.Cit. p.7
} 
distinção entre a análise do historiador, e a análise do filósofo. Pois o primeiro, procura os pensamentos políticos das pessoas que viveram em um período determinado, como conviviam na sociedade estudada e como seus comportamentos podem ser estudados através do método histórico. Já o filósofo, se preocupa em analisar o pensamento produzido e como este pensamento pode ser explicado racionalmente. ${ }^{131}$

Sendo assim, para John Pocock, o pensamento político é definido como uma série de abstrações da experiência, como já citei anteriormente, pensamento também que ele pode ser definido como a atividade de produzir e usar tais abstrações. ${ }^{132}$ Quais parâmetros são requeridos na historiografia para que possa ser habilitado que a explorar diferentes relações possíveis que permitem teorizar sobre a experiência e a ação?

A partir das conceituações utilizadas, existem dois campos de estudo divididos entre quando os conceitos são abstraídos da tradição e quando os conceitos são empregados na ação de uma tradição específica. Pocock, procura compreender a atividade do pensamento e depois, a atividade da ação política. ${ }^{133}$ Visto que, existe uma diferença entre o conteúdo intelectual de um pensamento e todo o papel que este conteúdo exerce influenciando uma ação política.

Pensando sobre o trabalho do historiador especificamente, Pocock alega que se um historiador das ações procura compreender e averiguar como as crenças e as ideias influenciam nas ações das pessoas e como nós compreendemos estas ações, o historiador do pensamento se preocupa com a atividade do pensamento, da concepção, da abstração de ideias de situações específicas e de tradições. ${ }^{134}$

"The historian of thought will be perpetually interested in thought as it takes shape under the pressure of immediate events, but this interest will not be exclusive. One is more likely to take as one's time studing how these are abstracted from traditions of behaviour, employed to criticize them and finally incorporated in them. Once one has taken this turn, one will tend to be concerned with thought as the language of

\footnotetext{
${ }^{131}$ Idem. p. 9

${ }^{132}$ Idem. p. 10

${ }^{133}$ Idem. p. 12

${ }^{134}$ Idem. p. 13
} 
tradition, rather than with action, though as one moves towards studying how traditional concepts are employed and modified in particular situations of action, one will approach the point where one's work shades into that of the historian os action as it is modified by thought." 135136

Desta maneira, para compreender a discussão política e assim compreender também o pensamento político do contexto analisado, deve-se observar os modos de crítica e de defesa da legitimidade do comportamento político, as referências trazidas por símbolos ou princípios e explorar as linguagens utilizadas e as formas de argumentação utilizadas. É importante atentar para quais os elementos são escolhidos pela sociedade estudada, para representar e validar o comportamento social, que serão escolhidos de acordo com as tradições culturais e estruturas sociais.

Pocock traz um ponto bastante interessante no que diz respeito a compreender o pensamento não apenas nos fenômenos imediatos, mas enxergar e pesquisar a fundo sobre como estes pensamentos são extraídos das tradições dos comportamentos. Desta maneira, existe a possibilidade de enxergar melhor uma série de nuances a respeito do objeto estudado, que no caso específico deste trabalho, é o compromisso dos Irmãos de Goiana. Neste sentido, analisando a linguagem da tradição, seguindo a proposta sugerida por Pocock acima, pode-se encontrar permanências e rupturas dentro da tradição de escrita das irmandades negras, ao mesmo tempo, podendo encontrar também possíveis especificidades do discurso dos Irmãos do Rosário de Goiana.

É importante salientar que sociedades estáveis e articuladas possuem conceitos e discussões através de várias linguagens diferentes, o que acarreta em diferentes divisões que trazem novos aspectos para a linguagem e para o vocabulário, no sentido de que, termos utilizados em outro sentido que não o seu sentido original, trazem um novo significado. Assim, o pensamento político de uma sociedade é construído através da adoção de vários aspectos diferentes das tradições

\footnotetext{
${ }^{135}$ Idibem.
} 
sociais e culturais e como elas são explicadas através da linguagem. Ou seja, como a linguagem é modificada para contemplar tais tradições trazendo seus significados e suas concepções de pensamento político. ${ }^{137}$

\begin{abstract}
"Once such languages have developed, thought about politics may become an autonomous theoretical activity and assume forms as political philosophy or political science; and it may be supossed that the historian of political thougnt is the historian of these forms of autonomous theory. But once we define political thought as the language of the political discussion, this cannot be so. For the pratical and the theoritical are not separable, and the same political question may be discussed, at one and the same time, in a vocabulary adapted from social tradition and a vocabulary specialized for making universal statements about political association as such." ${ }^{138}$
\end{abstract}

Tal passagem procura esclarecer a respeito da atividade de se analisar o pensamento político como a linguagem da discussão política, onde tal atividade deve ser dinâmica, pois ao mesmo tempo, o vocabulário sofre transformações e se adapta da tradição social e o vocabulário especializado realiza apontamentos sobre as associações políticas realizadas, simultaneamente, acontecem esses dois movimentos.

Para compreender a discussão política e desta maneira compreender também o pensamento político do contexto analisado, deve-se observar os modos de crítica e de defesa da legitimidade do comportamento político, as referências trazidas por símbolos ou princípios e explorar as linguagens utilizadas e as formas de argumentação utilizadas. É importante atentar para quais os elementos são escolhidos pela sociedade estudada, para representar e validar o comportamento social, que serão escolhidos de acordo com as tradições culturais e estruturas sociais.

Ainda sobre o trabalho do historiador do pensamento, sua função é procurar compreender as críticas ou defesas a legitimidade do comportamento político existente, compreender a quais símbolos e sinais que este comportamento está se referindo, além de analisar também a linguagem e as formas de argumentos que

\footnotetext{
${ }^{137}$ Idem. p. 15

${ }^{138}$ Ibidem.
} 
estão sendo utilizadas para tal comportamento. Ainda assim, é necessário atentar para o fato de que toda a organização conceitual empregada pela sociedade, além do conhecimento a respeito desta função, tem limitações necessárias. ${ }^{139}$ Além das preocupações colocadas acima, o pesquisador também deve desenvolver uma familiaridade com a linguagem estudada, além compreender que essa mesma linguagem possui vários níveis de abstração e é utilizada de maneiras diferentes.

John Pocock em seu trabalho, procura se aprofundar em como as idéias, articuladas através da consciência da tradição, vão de ideias abstratas a tradição, também se preocupa com a relação entre o pensamento e a estrutura da sociedade em questão. A sociedade e sua estrutura social analisada profundamente, pode trazer elementos da consciência dos indivíduos que vivem em tal contexto e assim, o pesquisador pode formular uma postura crítica em relação as falácias.

No seu segundo capítulo, "Working on ideias in time", Pocock traz uma reflexão sobre seu trabalho, quando aborda que escolheu estudar e descobrir como "passados" construídos conceitualmente surgem, ou como estes passados se relacionam com o presente e quais são os dispositivos que fazem com que esta relação possua autonomia crítica para podermos chamar de este movimento de história. ${ }^{140}$

Outro autor utilizado como referência para metodologia trabalhada neste capítulo é Quentin Skinner que também se dedica as diferentes interpretações a respeito do problema estudado. Em seu texto, "Motives, Intentions and the Interpretation of texts", traz uma concepção diferente acerca da interpretação de textos. O autor afirma a impossibilidade de criar leis gerais para a interpretação destes textos literários, pois é bastante questionável a subjetividade de tal interpretação. A partir de tal indagação, o autor traz uma reflexão muito importante, no sentido de compreender o quão perigoso é considerar que existem interpretações corretas ou uma única interpretação correta de algum texto, considerando que

\footnotetext{
${ }^{139}$ Idem. p. 16

${ }^{140}$ Idem. p..25
} 
interpretações diferentes da primeira interpretação ou da "correta", não podem ser consideradas erradas. ${ }^{141}$

Fernando Nicolazzi, sintetiza os métodos propostos por Skinner como uma correlação entre motivos, onde deve-se desenvolver três circunstâncias, sendo elas, o espaço do texto e sua escrita, o autor e a percepção do leitor sobre o texto e sua percepção externa ao texto. "Desta maneira, o pano de fundo que articula autortexto-autor é a noção de contexto, "uma espécie de corte de apelação para avaliar a plausibilidade relativa de atribuições incompatíveis de intencionalidade". ${ }^{142}$

Existe um acordo comum que define a interpretação como a ação de captura de uma mensagem de determinado texto e depois sua decifração, tornando o seu significado explícito. Partindo de tal afirmação, o autor traz algumas questões, no sentido de que a interpretação e seu estudo teriam como objetivo o melhor entendimento da mensagem para o receptor. Logo, questiona se não seria possível estabelecer uma lei geral sobre como a decifração de sinônimos de um determinado texto. $^{143}$

\begin{abstract}
"se os motivos têm um caráter íntimo, ligado à psicologia individual e, portanto, são externos à obra escrita, as intenções possuem uma dimensão eminentemente coletiva, estando inseridas em um âmbito comunicativo que implica uma legibilidade pública da obra. Assim, considera-se que a intenção está disponível na obra mesma, como um elemento discursivo, podendo ser vislumbrada no próprio texto, enquanto os motivos demandam outros objetos a serem investigados, tais como a Psicologia ou a Sociologia do autor."144
\end{abstract}

Seguindo a explicação de Skinner a respeito da captura e interpretação de mensagens, podemos compreender que o trabalho de interpretação consiste em um exercício que traz uma parcela de subjetividade por parte do pesquisador que analisa o texto. Desta maneira, é possível se obter interpretações e conclusões diferentes de

\footnotetext{
${ }^{141}$ SKINNER, Quentin. Motives, Intentions and the Interpretations of Texts. In: New Literary History, Vol. 3 , No.2, On Interpretation: I. (Winter, 1972), pp. 393-408. p.393

${ }^{142}$ NICOLAZZI. Op.Cit. p.26

${ }^{143}$ SKINNER. Op.Cit. p.394

${ }^{144}$ NICOLAZZI. Op.Cit. p.27
} 
trabalhos de História que abordam o mesmo tema no mesmo período temporal, pois cada pesquisador analisa o contexto estudado com o seu próprio olhar e suas experiências.

Como estratégia metodológica de compreensão de textos, Skinner traz uma proposta de utilizar três sentidos para compreender e assimilar melhor o significado de um texto e suas palavras. Desta maneira, o primeiro sentido consiste em entender o significado das palavras que foram utilizadas no texto em seu próprio contexto no qual elas foram utilizadas. O segundo sentido proposto por Skinner, se volta para o leitor, no sentido de que o exercício consiste em perguntar o que texto significa para sí mesmo, ou seja, para o próprio leitor, qual o seu sentido e por último, como terceiro sentido, questionar sobre o próprio autor do texto e o que esta pessoa quis dizer quando redigiu tal trabalho, quais suas intenções. ${ }^{145}$

É interessante refletir sobre o fato de que a interpretação não depende apenas do autor e do que tal autor escreveu, mas também depende da recepção, do olhar de quem está analisando e trazendo os seus próprios símbolos para dar significado e sentido ao texto que está sendo analisado.

Após esta primeira proposta de análise metodológica colocada por Skinner, o autor aborda os argumentos que avançam reivindicando que a crítica não pode ser uma tentativa de analisar os motivos e interpretações do autor, com a intenção de se compreender o sentido de um texto. Para ele, existem dois tipos de argumentação, uma que está ligada com os procedimentos críticos e sua integridade, além de não permitir que informações sobre o autor possam de certa forma "contaminar" a leitura e a interpretação em relação aquele trabalho ou sobre seu autor. ${ }^{146}$ Tal pensamento vem da ideia de que se atentar para estes fatos externos aos textos pode trazer a falsa impressão de compreensão do texto, porém sem se ater apenas ao que está contido no texto.

A segunda argumentação é colocada por Skinner como uma reflexão a respeito do que pode ser escondido, em se tratando do trabalho que está sendo

\footnotetext{
${ }^{145}$ SKINNER. Op.Cit. p.397

${ }^{146}$ Idem. p.397
} 
analisado e sobre as reivindicações que geralmente são feitas em relação as intenções e motivos. É bastante salientado pelo autor que, estas críticas devem ser lidas com uma cautela, já que é impossível desvencilhar o texto e o que está "dentro" dele do que está "fora" do texto, como por exemplo, informações sobre o autor ou outras obras do mesmo. ${ }^{147}$

\begin{abstract}
"To know a writer's motives and intentions is to know the relationship in which he stands to what he has written. To know about intentions is to know such facts as whether the writer was joking or serious or ironic or in general whats speech-act he was performing. To know about motives is know whats prompted thos paerticular speech-acts, quite apart from their caracter ans thus-statuas as utterances." ${ }^{148}$
\end{abstract}

A relação entre o conteúdo de um texto e a intenção de quem o escreveu pode ser exercida diretamente, quando o autor está escrevendo literalmente o que está de fato dito no papel. Em outros momentos, quando existem atos em relação ao o que está escrito, a análise deve ser mais específica procurando analisar com maior atenção aqueles atos que podem auxiliar na compreensão na correspondência entre as ações e os escritos analisados. ${ }^{149}$ As ações dos indivíduos e seus textos a respeitos destas ações podem ser comparadas às suas semelhanças e diferenças quando saem do campo do texto e se tornam realidade. Assim podemos trazer à tona uma série de detalhes a respeito da produção de tal texto e das intenções existentes com a sua produção de tal texto.

Ao longo de todo o texto, Skinner coloca que o leitor deve procurar saber o que o autor provavelmente quis dizer com o texto escrito e ao mesmo tempo, procurar saber sobre suas intenções ao escrever, porém tudo isso deve ser diferenciado da reivindicação de que estas intenções são mascaradas e que deve se decodificar o significado original. É interessante o fato de que o próprio Skinner afirma que ele não se sente convencido pela interpretação considerada certa, afirmando que a interpretação de um texto deve ser estudada de acordo com o contexto original em que o autor escreveu. Para ele, não há problema nenhum em ter

\footnotetext{
${ }^{147}$ Idem. p.399

${ }^{148}$ Idem. p. 400

${ }^{149}$ Idem. p.403
} 
uma interpretação pessoal de um trabalho que seja diferente do autor ou que o autor não tenha refletido sobre. ${ }^{150} \mathrm{~A}$ análise de um texto específico deve ser avaliada com muita atenção, pois deduções realizadas pelo leitor também podem trazer uma série de equívocos e o risco de falha de um crítico ao criar novas interpretações é grande. $^{151}$

Para se extrair mais informações a respeito de um texto, procurando conexões que possam iluminar melhor o próprio texto e o contexto em que ele foi escrito, é importante que o foco da análise não seja apenas no texto, mas também devem ser analisadas as convenções do período. Assim, pode-se perceber que tais regras e convenções, oficiais ou não, influenciam de maneira positiva ou negativa, as intenções e a maneira de se escrever um texto. Todas estas influências do período no qual o texto analisado foi produzido acabam expandindo ou limitando o sentido do texto, por isso, deve-se analisar quais as possibilidades que podem estar sendo omitidas. $^{152}$

A respeito de como compreender mais informações de um texto, Skinner coloca tal exercício como uma análise do "mundo mental" de quem escreveu o texto:

\footnotetext{
"focus on the wrister's mental world, the world of his empirical beliefs. The rule derives from the logical connection between our capacity to ascribe particular intentions to agents and our knowledge of their empirical beliefs. The rula can not only be applied critically but can again serve as an heuristic device." ${ }^{153}$
}

O foco está na necessidade de se levar em consideração outros aspectos além de apenas o texto propriamente dito. Neste sentido, Skinner traz em seu texto algumas sugestões de fatores que ao seu ver, devem ser levados em consideração para a análise e compreensão de textos. Sempre deve-se levar em consideração que o texto é um objeto ligado com que o criou, sendo assim, torna-se importante e

\footnotetext{
${ }^{150}$ Idem.p.405

${ }^{151}$ Ibidem.

${ }^{152}$ Idem. p.406

${ }^{153}$ Idem. p.407
} 
bastante elucidativo compreender o que o autor estava fazendo na confecção do texto e todo o contexto a sua volta. ${ }^{154}$

Desta maneira, mesmo que seja possível desvendar a biografia do autor e outras informações, estes dados não podem ser utilizados para compreender o sentido de um texto específico, pois assim, seria comprometida a suposta transparência dos procedimentos.

Nenhuma interpretação é totalmente pura, no sentido de que, todas as interpretações são contaminadas tanto pelo entendimento do pesquisador quanto por informações trazidas pelo próprio texto ou por informações externas, como por exemplo, informações bibliográficas.

A questão dos atos de fala dispensa o recurso da intencionalidade, pois para Pocock, no discurso existe uma lacuna entre a intenção e o efeito ou entre a consciência do efeito e o efeito de fato. Já por outro lado, Skinner, não aceita a existência de fatos ílocucionários não intencionais. Pocock nos diz que o que o autor estava fazendo nos traz a possibilidade de instigar respostas não previsíveis de terceiros.

É necessário perceber que Skinner e Pocock trazem concepções um pouco diferentes acerca da interpretação de textos. Enquanto Skinner presume a possibilidade de uma lei geral com passos específicos para a compreensão de textos, Pocock considera que a interpretação pode ser concebida através de vários níveis possíveis de abstração, portanto não existe a possibilidade da elaboração de um método ideal para a interpretação de textos. $\mathrm{O}$ autor afirma que tais interpretações dependem das abstrações alcançadas. ${ }^{155}$

\footnotetext{
${ }^{154}$ Idem. p.408

${ }^{155}$ POCOCK. Op.Cit.. p.13
} 


\section{Análise contextualista do Compromisso}

Como já afirmado anteriormente neste trabalho, o compromisso dos irmãos de Goiana, assim como outros compromissos de Irmandades no período colonial, deveria seguir uma série de exigências das autoridades eclesiásticas para serem validados e com isso poder respaldar o funcionamento da irmandade em questão. Sendo assim, logicamente os compromissos devem seguir um modelo, uma norma padrão para evitar maiores problemas com as autoridades, com isso, os compromissos são muito parecidos, onde não são colocadas muitas especificidades de cada irmandade.

Através dos parâmetros da metodologia contextualista, o compromisso deve ser explorado no sentido de se compreender as ideias, as tradições e costumes que moldam os modos de pensar do período e influenciaram tanto nos membros da Irmandade do Rosário dos pretos de Goiana, quanto na Coroa Portuguesa e na comunidade local. Neste sentido, as irmandades na América Portuguesa são um exemplo de instituição que se molda de acordo com o contexto no qual está inserida, trazendo a tradição católica e ao mesmo tempo sofrendo uma série de transformações tanto na sua esfera social, quanto na esfera espiritual. ${ }^{156}$

Durante todo o século XVIII, período de confecção do compromisso estudado, a importância das irmandades e confrarias se dá no sentido de que este era um espaço de socialização dos mais diversos grupos de africanos vindos através da diáspora, da escravidão e seus descentes, sendo eles, pardos, pretos, crioulos, cativos, livres ou de nação. Assim, a existência destes diferentes grupos e etnias no regime escravocrata da América Portuguesa se deu através da coerção e de outras formas de adaptação, entre elas, a conversão na fé católica, como nos explica João José Reis:

\footnotetext{
${ }^{156}$ BOSCHI. Op.Cit. p.12
} 


\begin{abstract}
"Antes mesmo que o primeiro escravo desembarcado no Brasil se rebelasse, os senhores e autoridades coloniais já sabiam ser necessário controlar seu corpo e seu espírito. O regime escravocrata, como todo regime de trabalho forçado, baseou-se fundamentalmente no chicote e em outras formas de coerção, mas não teria vigorado por muito tempo se só usasse a violência. Desde cedo os escravocratas aprenderam que era preciso combinar a força com a persuasão, assim como os escravos aprenderam ser impossível sobreviver apenas da acomodação ou da revolta. Os estudos mais recentes sobre a escravidão mostram justamente que a maioria dos escravos viveu a maior parte do tempo numa zona de indefinição entre um extremo e outro. Num trabalho recente, chamamos essa zona de espaço de negociação. Além da barganha relacionada à vida material e ao trabalho, os escravos e senhores, negros, forros, livres e homens brancos, digladiavam-se para definir os limites da autonomia de organizações e expressões culturais negras." 157
\end{abstract}

Neste contexto de negociações oscilantes entre coerção e permissão que as irmandades negras se mostram como um local de resistência, onde as festas, funerais, missas e todos os outros rituais existentes no interior destas organizações faziam com que os irmãos construíssem um sentimento de identidade e de pertencimento. ${ }^{158}$

No compromisso da Irmandade da Nossa Senhora do Rosário dos Homens Pretos da Vila de Goiana, também são encontradas as práticas citadas por Reis acima, presentes nas Irmandades espalhadas por toda a América Lusa, como o sepultamento e o funeral dos irmãos, a festa dedicada a Nossa Senhora e a coroação do rei e da rainha do Congo.

Analisando o compromisso de acordo com as circunstâncias políticas e sociais nas quais a irmandade se encontrava, o documento representa a tensão entre a coroa portuguesa e a relativa autonomia conquistada pela irmandade. É possível enxergar a autonomia dos irmãos quando são descritos no compromisso, por exemplo, os mecanismos de escolha sobre quem poderia ou não fazer parte da irmandade $^{159}$, ou quando estão definindo o valor das esmolas e tributos da

\footnotetext{
${ }^{157}$ REIS. Identidades étnicas. Op.Cit. p. 3,4.

${ }^{158}$ Idem.. p.4.

${ }^{159}$ Compromisso da Irmandade de nossa Senhora do Rosário dos homens Pretos da Villa de Goyanna (1783) - AHU_ACL_CU-Cod. 1717.p.250
} 
irmandade. Tal prática demonstra uma absorção das práticas brancas no seio da Irmandade composta por pretos, demonstrando que estes, adotaram tais práticas e as utilizam dentro de uma instituição administrada por eles mesmos. Ao mesmo tempo, tudo que está contido no compromisso, está subordinado a coroa portuguesa e necessita de sua aprovação para que seja possível o funcionamento da Irmandade, demonstrando de alguma maneira, o sucesso no projeto de catequização dos povos escravizados.

Focando no estilo do compromisso dos irmãos pretos do Rosário de Goiana pode-se perceber que o texto utiliza uma linguagem bastante rebuscada, demonstrando que provavelmente o escrivão da Irmandade possuía um conhecimento formal maior do que a maioria da população cativa e seus descendentes durante o período estudado, afinal, estes em sua grande maioria não sabiam ler nem escrever. Através do compromisso não podemos afirmar o nível de instrução do Escrivão, ou se este sabia ler ou não, porém o fato é que o compromisso foi escrito por alguém que tinha um vasto conhecimento sobre o vocabulário utilizado pelas autoridades eclesiásticas e exercia uma função bastante importante dentro da confraria. Segundo o capítulo XVI do compromisso:

"Da obrigação do Irmão Escrivão

O Irmão Escrivão fechará os livros e os mais papéis da Irmandade e nelles cumprirá com a sua obrigação nos assentos dos Irmãos que de novo entrarem, e lançar as contas que ouverem nos livros que lhes competir dando-as e tomando-as em prezença de de toda a Mesa a nenhum tempo poderá particularmente a isentar irmão algum sem que prezencie os demais da Mesa, e de cuja entrada fara termo no livro delles na conformidade e ordenação deste compromisso, e só fará entrega dos sobretidos livros no fim do anno de seo governo ao Escrivão sucessor que se eleeger, por que desta sorte se evitão as mas suspeitas e dellas se dezonera sobredido escrivão e conclue o seu anno sem nota nem defeito:

ultimamente segue-se o lugar do Juiz da Mesa, como segunda pessoa depois d Irmão Juiz." 160

\footnotetext{
${ }^{160}$ Idem. p. 260
} 
Pode-se perceber através da descrição do cargo de escrivão que a pessoa que ocupasse tal cargo tinha uma grande responsabilidade na irmandade, cuidando não apenas dos livros, mas também de lançar as contas da irmandade e de dar as entradas dos irmãos nos livros, entre outras funções.

Sendo assim, o estilo do texto é extremamente ligado com a sua intenção, que no caso da fonte estudada, é a apresentação e aprovação do compromisso para a coroa portuguesa. Assim, a linguagem do compromisso e a maneira como o texto se refere as autoridades e a reverência realizada a coroa demonstram a necessidade de aval das autoridades e sua importância para irmandade:

"Os pretos da Vila de Goyanna do Recife de Pernambuco humildes e fiés vassalos de Vossa Magestade para melhor praticarem as virtudes christaes e conceguirem a suma e eterna felicidade estabelecerao uma pia corporação da confraria do soberano Rosário de Maria Santissima..." ${ }^{16}$

De acordo com as reflexões trazidas pela metodologia contextualista, o compromisso se faz um texto muito interessante para a análise, pois no caso específico estudado, a tradição se faz extremamente importante para a compreensão de como o texto foi escrito. A importância da tradição se encontra no fato de que os compromissos de Irmandades de toda a América Lusa deveriam seguir uma série de pré-requisitos já estabelecidos ${ }^{162}$ que o fizessem ser um documento válido, fazendo com que o documento não fosse aprovado caso se diferenciasse muito de outros compromissos já aceitos pela tradição criada. Portanto, devido a tal tradição, não era possível inovar muito na escrita de um compromisso, no sentido de fugir do que geralmente era colocado nos compromissos de irmandades na América Lusa.

Segundo as concepções acerca da tradição do comportamento, descrita por Pocock, podemos compreender a Irmandade dos pretos do Rosário de Goiana e seu compromisso, como um resultado do sistema colonial vigente, onde o passado social vivido era a da constante construção da sociedade colonial.

\footnotetext{
${ }^{161}$ Idem. p. 277

${ }^{162}$ SIMÃO. Op.Cit. p.78
} 
"Ao serem arrancados de seus lugares de origem e escravizados, ao deixarem de pertencer a um grupo social no qual construíam suas identidades, ao viverem experiências de grande potencial traumático, tanto físico como psicológico, ao transporem a grande água e terem que se dobrar ao jugo dos senhores americanos, os africanos eram compelidos a se integrarem, de uma forma ou de outra, às terras às quais chegavam. Novas alianças eram feitas, novas identificações eram percebidas, novas identidades eram construídas sobre bases diversas: de aproximação étnica, religiosa, da esfera do trabalho, da moradia. Assim, reagrupamentos étnicos compuseram "nações", pescadores e carregadores se organizaram em torno das atividades que exerciam, vizinhos consolidaram laços de compadrio e se juntaram cultuadores dos orixás, os que faziam oferendas aos antepassados e recebiam entidades sobrenaturais sob o toque de tambores. Nesse contexto, os reis negros, presentes em quilombos e grupos de trabalho, mas principalmente em irmandades católicas, serviram de importantes catalisadores de algumas comunidades e foram centrais na construção de suas novas identidades." 163

Como nos explica Marina de Mello e Souza, as alianças criadas pelos africanos e seus descentes aconteceram de acordo com as condições do contexto colonial, onde as Irmandades católicas representavam um local importante de formação de novas identidades e maneiras de viver. Neste sentido, pode-se se compreender o compromisso como um produto do pensamento diretamente ligado às tradições do comportamento das Irmandade negras em seu contexto. Assim, é bem coerente que o compromisso de fato se assemelhe aos outros compromissos, tanto na forma, quanto no conteúdo. Pois desta maneira, seria mais fácil conseguir fazer com que a irmandade iniciasse o seu funcionamento. Estas mesmas tradições também são o que fazem os irmãos saber o que colocar ou não nas páginas do compromisso, o que falar e o que pode ser omitido, em detrimento da própria irmandade.

Segundo as sugestões propostas por Skinner e a contextualização do período histórico no qual o compromisso se situa, pode-se compreender como se procede a intenção de conquistar os direitos de funcionar da Irmandade. Neste sentido, a

${ }^{163}$ SOUZA, Fernando Prestes de. LIMA, Priscila de. "Que haja paz e quietação": controle social e irmandades negras na América Portuguesa. Século XVIII. Revista Ágora, Vitória, n.11, 2010, p.1-22. p.128 
crença e a fé à Nossa Senhora estão expostas no compromisso, demonstrando assim, o seu sentido explícito e a importância da Irmandade para estes indivíduos. Outras práticas que poderiam ser realizadas não precisam e não deveriam estar expostas no compromisso, já que o documento já tinha sua forma ou seu estilo já previamente definido pelas convenções impostas pelas tradições.

Através de outro olhar, segundo a visão do leitor em relação ao compromisso, é nítido que a coroa tinha a intenção de manter um controle em relação as irmandades católicas que desejavam funcionar em todo território da América Lusa. Segundo Scarano, o controle realizado pela coroa portuguesa com as irmandades católicas existentes na colônia era mais rigoroso do que o controle realizado na metrópole, porém, a coroa não tinha um diálogo frequente com Roma, portanto, tal fiscalização era realizada de maneira limitada. ${ }^{164}$

Desta maneira, o controle da coroa como leitora do compromisso era no sentido de conferir se as irmandades estavam seguindo as convenções já impostas pela tradição, não mantendo uma fiscalização rigorosa no dia-a-dia da Irmandade, trazendo assim, uma permissividade maior para os irmãos, suas práticas religiosas e relações sociais e políticas.

A análise contextualista se mostra uma metodologia bastante proveitosa para a compreensão e exploração do compromisso, pois traz a possibilidade de aprofundar o estudo em toda a conjuntura do processo de produção da fonte, levando em consideração os motivos da realização do compromisso e a sua finalidade. Além disso, permite explorar as construções das tradições do período de confecção do compromisso e como estas tradições afetam na fonte e nos indivíduos que eram afetados pelo compromisso.

\footnotetext{
${ }^{164}$ SCARANO, Julita. Devoção e Escravidão. A Irmandade de Nossa Senhora do Rosário dos Pretos no Distrito Diamantino no Século XVIII.- 2. ed. São Paulo: Ed. Nacional, 1978.p.19
} 


\section{Conclusão}

Ao longo de toda a dissertação, o compromisso foi trabalhando através de diferentes óticas metodológicas para que desta maneira, este documento pudesse ser estudado e explorado como fonte histórica.

No primeiro capítulo, por meio de uma análise crítica do compromisso da Irmandade de Nossa Senhora do Rosário dos Homens Pretos da Vila de Goiana, examinamos a veracidade do documento depois de compará-lo com o compromisso da Irmandade de Bom Jesus dos Martírios dos Pretos de Recife, trazendo uma série de questões a respeito dos dispositivos de validação de tais compromissos, como as semelhanças na sua forma. Isto é, os compromissos seguem a forma da maioria dos estatutos de Irmandades de brancos e pretos durante o século XVIII na América lusa. Porém, eles se diferem no fato de que o compromisso de Goiana é mais detalhado do que o compromisso de Recife. A análise crítica do compromisso permite a reflexão a respeito do que está contido e omitido no documento, logo, algumas descrições são mais importantes que outras, considerando que o documento foi confeccionado para ser aprovado pela Coroa portuguesa. De modo que, já no seu primeiro capítulo, onde se define quem poderia fazer parte da Irmandade, é curiosa a permissividade da Irmandade em relação à possibilidade de abertura a vários sujeitos da sociedade em que se inseria.

As Irmandades são de alguma maneira, um local de grande disseminação da fé católica e um dos ambientes onde o projeto de colonização se concretizava. Pois a conversão e a prática da fé católica, representavam uma maneira de controle dos senhores sobre seus escravos, e, ao mesmo tempo, as Irmandades eram um dos poucos espaços onde tais irmãos partilhavam uma autonomia em relação ao sistema escravista.

A tensão entre as autoridades e a população de pretos perduravam durante o período colonial e podem ser percebidas através das Irmandades negras. No caso específico da Irmandade dos pretos de Goiana, o compromisso inteiro se concentra 
nas obrigações dos irmãos e exaltando os privilégios de fazer parte da confraria, não falando em momento algum a respeito da satisfação ou felicidade no culto à Nossa Senhora do Rosário. Tal situação torna curioso o fato do porquê tais indivíduos se filiavam a irmandade, afinal, a filiação não era compulsória e para fazer parte era necessário que os irmãos cedessem uma quantia em dinheiro definida de acordo com a sua cor:

É sabido de que os irmãos deveriam demonstrar devoção e fé para se manter na irmandade, além de cumprir com as obrigações dispostas para cada cargo. Porém, o espaço de organização política entre pretos e brancos irmãos e a relação da irmandade enquanto instituição com o resto da sociedade da vila de Goiana podem ter sido alguns dos atrativos para a filiação de a manutenção de indivíduos dentro da organização. No primeiro capítulo do compromisso, que versa sobre os irmãos que desejavam participar da irmandade, é colocado como exigência que os irmãos pretos deveriam se entender com as pessoas brancas e pardas caso quisessem se manter dentro da irmandade. Fica explícito que em outros ambientes este tipo de conflito pode ter existido, desta maneira, o caráter da Irmandade enquanto instituição política de peso é reforçado, impondo estas pessoas a uma boa convivência.

A respeito dos benefícios ao se tornar um irmão, o compromisso explica que a família do irmão, ou seja, sua esposa e filhos, poderiam desfrutar dos mesmos benefícios caso o irmão falecesse ou caso sua esposa falecesse. Esta cláusula demonstra que os africanos e seus descendentes poderiam desfrutar dos privilégios de ser irmão e possuir uma família, nos moldes europeus. Além de demonstrar um controle na vida destes indivíduos dentro e fora da irmandade, também permite uma organização destas pessoas, perpetuando assim tradições, práticas sociais e religiosas.

Em outros momentos, alguns capítulos são dedicados aos cargos existentes na irmandade, com isso, pode se perceber que existe uma hierarquia de importância dos cargos, além de existir a coroação do rei e da rainha do congo. Tais postos de diferentes posições de importância demonstram o valor que tais postos tinham 
internamente e externamente, além de ser um incentivo para os irmãos manterem as atitudes de zelo e cuidado.

As práticas da Irmandade do Rosário dos pretos de Goiana permitiram a criação de um ambiente dual, no sentido de que ao mesmo tempo a Irmandade representa a ordem, o controle e a conversão dos escravos, a mesma instituição abre brechas para a construção de novas configurações de organização social, financeira política e permite o surgimento de um espaço de resistência ao sistema escravista.

A respeito da análise linguística do compromisso, o documento é visto como um texto bastante direto que traz em seu conteúdo o discurso dos Irmãos pretos de Goiana e que transmite a ideia de rigidez ao tratar das regras e normas da irmandade. Percebe-se que o compromisso é um documento centrado nele mesmo, abordando apenas assuntos relacionados a regras da irmandade, não abrindo espaço para outras situações que poderiam ocorrer na confraria. O rigor da sua forma, demonstra a importância da autorização da coroa para o funcionamento da entidade, desta maneira o que poderia acontecer dentro da irmandade em seu cotidiano fica omitido.

Torna-se interessante salientar que a omissão de situações no discurso do compromisso permitiu que estes indivíduos se organizassem para que pudessem perpetuar suas práticas culturais e religiosas dentro da confraria. Existe uma lacuna entre o período de fundação da Irmandade e as festas ocorridas na irmandade no século XIX. No entanto, as suas tradições e costumes que não estão expressas no compromisso de fundação, podem ser percebidas nas transformações e ressignificações das manifestações culturais de Goiana ao longo da sua história.

Ainda abordando as metodologias trazidas a linguística para o trabalho, pode se perceber estatisticamente como o texto está voltado para sua auto explicação, trazendo os termos mais citado ao longo de todo o compromisso. Tal metodologia não permitiu maiores considerações a respeito do documento, porém serviu como uma reafirmação do método de análise do discurso.

O terceiro capítulo deste trabalho traz a análise retórica para o estudo do compromisso e, desta maneira, possibilita a reflexão a respeito de uma série de 
questões em relação ao discurso contido no documento. O compromisso dos irmãos de Goiana é um documento completamente rígido em sua forma e em seu conteúdo, estritamente voltado para explicar para a coroa portuguesa quais eram as leis que regiam a irmandade, sendo assim, não existe espaço para outros costumes serem colocados no texto. Esta rigidez que está presente na forma do texto e na descrição das leis da irmandade pode indicar um problema na agremiação. Se a filiação não era obrigatória e as pessoas que desejassem e tivessem a conduta esperada podiam entrar na irmandade, porque era necessário utilizar da coerção para com estes indivíduos?

Em alguns momentos, parece que o texto do compromisso estava interessando em explicar sobre o quanto iriam fazer o possível para não haver brigas, desavenças, inimizades entre os irmãos e nenhuma conduta que fugisse da boa fé e do zelo. O texto cita a todo momento que o não cumprimento de tais regras resultaria em uma punição, onde a pena máxima seria a expulsão do membro da irmandade. Tal modo de conduzir as atitudes inadequadas é curioso, pois a irmandade era um espaço de devoção á Nossa Senhora do Rosário e crescimento espiritual. $\mathrm{O}$ documento versa a respeito de uma confraria religiosa onde não são explicados os cultos e as formas de devoção. A ênfase é dada àquilo que os irmãos não deveriam fazer e a sua organização em cargos, mostrando novamente que o compromisso era um documento destinado a regulamentação e alinhamento à coroa portuguesa. Sem demonstrar, portanto,muita atenção ao registro dos rituais religiosos da irmandade ou as formas de devoção de seus membros.

Como a adesão de pessoas nas irmandades e em outras organizações católicas demonstra um certo triunfo para o projeto de colonização e evangelização, torna-se contraditório a punição extrema e exclusão de um membro que comete infrações na irmandade, haja a vista a importância do perdão nos preceitos católicos. Além disso, não é interessante para irmandade, que as pessoas comecem a ser expulsas, pois a confraria deveria funcionar como um lugar de agregação. Portanto, a rigidez na pena dos irmãos parece ser uma forma de amedrontar estas pessoas para que elas se comportem de acordo com as convenções impostas e de maneira que não 
oferecessem algum tipo de perigo para a organização da irmandade, ou para comunidade externa.

A seguir, no capítulo XXI do compromisso, estão colocadas as obrigações gerais dos irmãos, onde é explicado as condições para que algum irmão seja admoestado sobre sua atitude e não mude. Neste caso, este membro seria banido da irmandade e poderia voltar caso peça perdão por suas faltas. ${ }^{165}$ Tal trecho demonstra que o objetivo do compromisso era intimidar e controlar seus integrantes para que não houvesse grande problemas dentro da irmandade. Além disso, a manutenção da ordem nas relações internas era interessante para a boa reputação da confraria e de seus representantes.

Ademais, podemos perceber que os irmãos que estavam na direção da irmandade ocupavam uma posição hierárquica superior à dos outros irmãos, detendo o poder e o controle financeiro de grande parte da instituição. Deste modo, mais uma vez evidencia-se o caráter da irmandade enquanto uma instituição de mobilização política na ordem escravista e com relações de disputa de poder também em seu interior.

Pode-se encarar o medo e as punições citadas acima como um mecanismo de controle dos irmãos para evitar possíveis revoltas e desobediências, tanto no ambiente externo quanto dentro da irmandade. Por outro lado, a boa imagem da confraria e de seus membros era importante para as relações políticas locais, portanto, era interessante manter os irmãos sob controle do regimento. É interessante ressaltar que o compromisso transmite uma imagem de rigidez e obediência às normas da coroa. Porém, sabe-se que estas organizações eram um espaço de autonomia em relação a maioria dos outros ambientes em que estas pessoas viviam. Como podemos observar a partir da possibilidade de auto-organização e arrecadação de fundos para a instituição, previstos no próprio compromisso. 
O quarto capítulo versa a respeito metodologia contextualista para a análise do estatuto. Ao analisá-lo enquanto um produto de toda conjuntura social e temporal no qual o documento está inserido, pode-se perceber quais convenções e tradições que estão validadas naquele momento. As considerações já colocadas neste trabalho afirmam o quanto o compromisso corresponde a um documento de rigor, trazendouma das maneiras da igreja católica e da Coroa portuguesa controlarem e expandirem a fé católica na América Lusa e difundirem o processo colonizador.

Partindo do pressuposto de que as tradições perpetuadas através do discurso do compromisso de Goiana representam o pensamento político vigente, de maior autoridade no período, deve-se questionar quais seriam as outras tradições e práticas existentes dentro da Irmandade do Rosário dos pretos de Goiana.A reposta para esta questão não é visível apenas com a análise do compromisso. Assim, algumas brechas deixadas pelo compromisso são o máximo que podemos perceber de comportamentos desviantes em relação aos costumes católicos vigentes.

A irmandade do Rosário dos pretos de Goiana aceitava todas as pessoas de cor preta do Brasil, do Reino de Angola e do Reino da Guiné, que quisessem fazer parte da confraria. Porém irmãos pretos, deveriam pagar quatro patacas de esmola pela sua entrada, enquanto irmãos brancos e qualquer irmão mordomo que se eleger pardo deveria pagar dois mil réis. Com taxas estipuladas, além de outras maneiras de organização criadas internamente, pode-se perceber como estes indivíduos criaram no seio da irmandade suas próprias tradições, aceitando também as mulheres como irmãs.

Através de todos estes detalhes contidos no compromisso, pode-se enxergar como a Irmandade de homens pretos de Goiana demonstra a sua autonomia em relação a outras instituições do período em vários aspectos, acomodando suas práticas cotidianas às tradições católicas colocadas pela Igreja católica.

Os compromissos de irmandades são fontes ricas para a análise do período colonial, de maneira que trazem um panorama do contexto de sua escrita e da irmandade da qual fazem parte. As metodologias abordadas neste trabalho auxiliaram no entendimento da atividade dos irmãos e irmãs do Rosário de Goiana e 
demonstraram que mesmo utilizando apenas um documento, é e foi possível explorar e apresentar um rico panorama da população negra da vila de Goiana no período colonial. 


\section{Fontes Primárias}

Compromisso da Irmandade de nossa Senhora do Rosário dos homens Pretos da Villa de Goyanna (1783) - AHU_ACL_CU-Códice. 1717

Compromisso da Irmandade do Senhor Bom Jesus dos Martírios dos Pretos da Villa de Santo Antônio do Recife de Pernambuco. (1788) - AHU_ACL_CU-Códice. 1913 


\section{Referências bibliográficas}

ALVES, Naiara Ferraz Bandeira. Irmãos de cor e de fé: irmandades negras na Parahyba do século XIX. UFPB, 2006.

BARBALHO, Luciana de Carvalho. Capitania de Itamaracá, poder local e conflito: Goiana e Nossa Senhora da Conceição (1685-1742). Dissertação (Mestrado) Universidade Federal da Paraíba. Centro de Ciências Humanas, Letras e Artes. História, 2009.

BASTIDE, Roger. As religiões africanas no Brasil: Contribuição a uma sociologia das interpenetrações de civilizações. São Paulo: Editora da Universidade de São Paulo, 1971, vol. II.

BEZERRA, Janaína Santos. Pardos na cor \& Impuros no Sangue: etnia, sociabilidades e lutas por inclusão social no espaço urbano pernambucano do XVIII. - UFRPE - Recife, 2010.

BLOCH, Marc. Apologia da história, ou, O ofício de Historiador. - Rio de Janeiro: Jorge Zahar Ed. 2001.

BORGES. Célia Maia. Escravos e libertos nas Irmandades do Rosário: devoção e solidariedade em Minas Gerais: séculos XVIII e XIX. Juiz de Fora: Editora da UFJF, 2005

BOSCHI, Caio. Os Leigos e o Poder (Irmandades Leigas e Política Colonizadora em Minas Gerais).Editora Atica, 1986.

CARDOSO, Ciro Flamarion. VAINFAS, Ronaldo. História e análise de textos. In: CARDOSO, Ciro F. ; VAINFAS, Ronaldo (Orgs.). Domínios da História. Ensaios de teoria e metodologia. Rio de Janeiro: Campus, 1997.

CARVALHO, José Murilo de. História intelectual no Brasil: a retórica como chave de leitura. Topoi, Rio de Janeiro, ${ }^{\mathrm{o}}$ 1, jan./dez. 2010.

HAMPÂTÉ BÁ, Amadou. Introdução à cultura Africana. Lisboa: Edições 70, 1970.

KARASCH, Mary C. A vida dos escravos no Rio de Janeiro, 1808-1850. São Paulo: Companhia das Letras, 2000.

LANGLOIS, Ch. V.; SEIGNOBOS, Ch. Introdução aos estudos históricos. Tradução Laerte de Almeida Morais. São Paulo: Renascença, 1946

LARA, Silvia Hunold. Fragmentos setecentistas: Escravidão, Cultura e Poder na América Portuguesa. Campinas: Unicamp, 2004.

LIMA, Maria da Vitória Barbosa. Liberdade Interditada, Liberdade Reavida: escravos e libertos na Paraíba escravista (século XIX) - Brasília: FCP, 2013 
MELlO E SOUZA, Marina de. Catolicismo Negro no Brasil: Santos e minkisi, uma reflexão sobre miscigenação cultural. Afro-Ásia, número 28, 2002, pp. 125-146, UFBA - Brasil. Disponível em: http://www.redalyc.org/articulo.oa?id=77002805

MELlO E SOUZA, Marina de. Reis do Congo no Brasil, séculos XVIII e XIX. Revista de História, núm. 152, junho, 2005, pp 79-98. USP - São Paulo, Brasil. Disponível em: http://www.redalyc.org/articulo.oa?id=285022040004

NICOLAZZI, Fernando. Um estilo de História: a viagem, a memória, o ensaio: sobre Casa-grande \& senzala e a representação do passado.São Paulo: Ed. Unesp, 2011. 484p.

OTT, Carlos. "A igreja da Barroquinha”. Anais do Arquivo Público do Estado da Bahia, vol.45, 1981.

PARÉS, Luís Nicolau. A formação do Candomblé: história e ritual da nação jeje na Bahia. Campinas, Ed. da Unicamp, 2007

PERELMAN, Chaïm, OLBRECHTS-TYTECA, Lucie. Tratado da argumentação: a nova retórica. Tradução de Maria Ermantina Galvão G. Pereira, São Paulo: Martins Fontes, 2. reimpressão, 1996.

POCOCK, John. Political Thought and History - Essays on Theory and Method.Cambridge University Press, 2009

REGINALDO, Lucilene. Os Rosários dos Angolas: Irmandades de Africanos e Crioulos na Bahia Setecentista. São Paulo: Alameda, 2011.

REGINALDO, Lucilene. Irmandades e devoções de africanos e crioulos na Bahia setecentista: histórias e experiências atlânticas. In: STOCKHOLM REVIEW OF LATIN AMERICAN STUDIES Issue No. 4, March 2009

REIS, João José. Identidade e Diversidade Étnicas nas Irmandades Negras no Tempo da Escravidão. Tempo, Rio de Janeiro, vo.2, n³, 1996

REIS, João José. Tambores e Temores: a festa negra na Bahia na primeira metade do Século XIX. In: Carnavais e outras F(r)estas: ensaios de história social da cultura. Campinas: Editora da Unicamp, Cecult, 2002.

ROBIN, Regine. História e lingüística. São Paulo: Cultrix, 1977

VASCONCELOS, Myziara Miranda da Silva. "Pela Vontade de Deus e bem dos Homens": o bem-morrer no documentos das Irmandades de pretos do Pernambuco colonial. Associação Nacional de História - ANPUH - XXIV SIMPÓSIO NACIONAL DE HISTÓRIA - 2007

SCARANO, Julita. Devoção e Escravidão. A Irmandade de Nossa Senhora do Rosário dos Pretos no Distrito Diamantino no Século XVIII.- 2. ed. São Paulo: Ed. Nacional, 1978. 
SILVA, Maria de Jesus Santana. Devoção e Resistência: As Irmandades de Homens Pretos de Goiana (1830-1850). Dissertação (Mestrado) - Universidade Católica de Pernambuco, Recife, 2008.

SILVEIRA. Renato da. O camdomblé da Barroquinha: processo de contituição do primeiro terreiro baiano de keto. Salvador: Edições Maianga, 2006.

SILVEIRA, Renato da. "Sobre a fundação do Terreiro do Alaketu", Afro-Ásia, 29-30 (2003) 345-79.

Disponível

em: http://www.afroasia.ufba.br/pdf/afroasia_n29_30_p345.pdf.

SIMÃO, Maristela dos Santos. As irmandades da Nossa Senhora do Rosário e os Africanos no Brasil do Século XVIII.Faculdade de Letras, Universidade de Lisboa, 2010.

SKINNER, Quentin. Motives, Intentions and the Interpretations of Texts. In: New Literary History, Vol. 3 , No.2, On Interpretation: I. (Winter, 1972), pp. 393-408.

SLENES, Robert. Malungu Ngoma Vem! A África coberta e descoberta do Brasil. Revista da USP. Dez-jan-fev., n ${ }^{\circ} 12,1991 / 1992$.

SOARES, Mariza de Carvalho. Devotos da Cor. Rio de Janeiro: Civilização Brasileira, 2000

SOUZA, Fernando Prestes de. LIMA, Priscila de. "Que haja paz e quietação": controle social e irmandades negras na América Portuguesa. Século XVIII. Revista Ágora, Vitória, n.11, 2010, p.1-22.

STONE. Lawrence. Prosopografia. Rev. Sociol. Polit. [online]. 2011, vol.19, n.39, pp. 115-137. ISSN 0104-4478. http://dx.doi.org/10.1590/S0104-44782011000200009.

THORNTON, John Kelly.A África e os Africanos na formação do mundo atlântico, 1400-1800. Rio de Janeiro: Elsevier, 2004.

VERGER, Pierre. Orixás: deuses iorubás na África e no novo mundo. Salvador: Corrupio, 2002. 


\section{Anexo}

Transcrição do Compromisso da Irmandade da Nossa Senhora do Rosário dos homens pretos da Villa de Goyanna (1783):

0245

Título é o seguinte

Título

Compromisso da Irmandade de Nossa Senhora do Rosário dos homens pretos da Vila de Goyanna novamente feito no ano de mil setecentos oitenta e três, sendo cappelião o Irmão de Muito Reverendo Padre Bernardo de Cavalho, Juiz o Irmão Antônio José de Fragoa, Escrivão o Irmão Antônio Dias, Procurador o Irmão Antônio Francisco Grillo, Thesoureiro o irmão José Ferreira

0246

somente me apontaram o que visto e examinado por mim he seguinte Apontado

Cumpra-se porem dentro de um anno Haverão igual aprovação pela mesa da consciencia e ordens, segundo as provisões passados este juizo, aliás passado o dito no executares a respectiva saneção. De que não ficão absolvidos pela confirmação que apresentão Paraíba oito de Abril de mil setecentos oitenta e cinco.

He a que tão somente me foi apontado do refediro livro a que me reporto que tornei a entregar a quem me apresentou Lisboa seis de Fevereiro de mil oitocentos e sete annos. \{Assinaturas $\}$

0247 - em branco

0248

Compromisso de nossa senhora do Rozario dos homens pretos da villa de Goyanna novamente feito anno de MDCCLXXXIII sendo capelão Bernado de Carvalho, juiz 
Ir. Antonio Jozé de Fragoa, escrivão o Irmão Antonio Dias, Paulo. Irmão Jozé Ferreira Estrella.

o Irmão Jozé Ferreira Estrella

0249 - cópia da 0248

0250

I O Ir: Manuel Viegas

II O IR: Antonio Anaceto

III O Ir: Jozé Maria

IV O Ir: Felipe do Carmo

V O Ir: Antonio Raimundo

VI O Ir: Marcelo Soares

VII O Ir: Miguel de Mattos

VIII O Ir: Precidonio Garcia

IX O Ir: João do Carmo

X O Ir: Joaquim Dourado

XI o Ir: Gonçalo da Cruz

XII O Ir: [ILEGÍVEL] do Canto

Capítulo I - Dos irmãos que se quiserem agregar na Irmandade

Primeiramente se admitirá por Irmão desta Santa Irmandade todas as pessoas de cor preta do Brazil do reyno de Angola e do Reyno de todo o gentio da Guiné afim libertos como sugeitos dos quaes não haverá número certo sim aceitarão quantos quizerem entrar, e dos que souber de receber por Irmão se examinara se sabem Doutrina Cristã para bem receberem a sagrada comunhão igualmente e se entender com as pessoas brancas e pardas que quizerem ser Irmãos desta santa Irmandade e 
todo geralmente antes disserem escritos no livro de entradas protestarão perante a Juiz e os demais da Mesa de que na dita Irmandade sirvão a Deus nosso senhor e a sua Santissima Mãe com aquele zelo, fervor e humildade devida a tão grandes magestades, para que assim cumprão em tudo os estatutos deste compromisso e gozarem das plenarias Indulgencias concedidas desta Santa Irmandade.

0251

\section{Capítulo II}

Irmãos e as postulas de suas entradas

Querendo qualquer pessoa [ILEGÍVEL]homens como mulheres entrar nesta Santa irmandade, virá a meza a presença do Juiz e mais Irmãos dela a pedir humildemente o haja de aceitar por Irmão e logo admoestava sem nome para se fazer assento no livro delle e dará de esmola da sua entrada sendo Irmão preto quatro patacas e sendo branco, dois mil réis cuja quantia de dois mil réis tão bem pagará qualquer irmão Mordomo que se eleger tanto pardo, como branco e de annual pagara geralmente cada hum, Irmão de cor preta parda e branca cento e secenta reis no fim decada hum anno.

Capítulo III - Do privilégio dos Irmãos, sua mulher, seus menores filhos

A pessoa que entrar por Irmão sendo casado e haja de falecer sua mulher será esta sepultada como se fora irmão da Irmandade com Tumba. Guião e acompanhamento exceto as Missas que de nenhuma partecipará, e sendo faleça primeiramente o marido que rendo ella cumprir com o tributo dos annaes ficará sendo perpetua e verdadeira Irmã gozando dos privilégios e indulgencias concedidas a esta santa Irmandades e cazo haja filiação no dito cazal, a estes te a idade de doze annos se lhes fará o mesmo beneficio qual fica dito no enterramento de sua mãe, isto he sendo filho de matrimonio e do contrário não gozará de beneficio algum da Irmandade.

0252

Falecendo algum irmão fará o Irmão sacristão diariamente os sinais que possível for de sepultar o corpo, principalmente pelo menos sino vendo o Irmão. Irmão simples e 
sendo Juiz terá o primeiro dobre no sino grande, e o escrivão, e Procurador meio dobre no dito sino grande, e salvara o Irmão andador com acampa pelas duas a noticiar os Irmãos para se ajuntarem na Santa Caza da Irmandade, para desta sahirem em duas allas, ornadas de Opas com a condução da Cruz, guiao, e tumba da Irmandade, a conduzir o corpor da Caza donde estiver, e pela alma do dito Irmão se mandarão dizer oito Missas pelo no R. P. Capelão, e mais sacerdotes nossos Irmãos, nesta Santa Caza e sendo ditas em outra qualquer Igreja não se lhes levará em conta as despesas a dellas derem o irmão procurador, e tesoureiro e o Irmão Escrivão por a memorial na Sacristia para se dizerem não devendo o Irmão algum dia se descontará.

Capítulo V - Dos cargos que hão de ocupar os Irmãos por hum anno

Haverá nesta Santa Irmandade hum Juiz da Mesa, hum escrivão, hum Procurador, hum tesoureiro, doze mordomos a saber seis nacturales do Brazil, e seis do gentio de Angola, ou Costa de Leste: Hum Andador, hum Sacristão, que todos estes serão eleitos por votos, e se procurará para esta eleição pessoas zelozas, tementes a Deos, de boa vida e san conciência e nunca em casa hum dos deferidos cargos poderão servir os Irmãos. que ocuparem mais que hum anno, para tão bem servirem os demais Irmãos, salvo se estiver a Irmandade com obra continuada, e foram ditos Irmãos zelosos na execução dela, porque nesse cazo poderão ficar 2 eleitos o seguinte anno para finalizar a deferida obra. Tem o Irmão procurador, emcumprindo bem como sua obrigação o poderão conservar no dito cargo todo o tempo que lhe conceder a Irmandade, e para que estes porfão dar enteira execução aos

0253

aos negócios pertencetes a esta Irmandade, he mui necessário e conviniente seja o juiz ou o escrivão da Mesa liberto, , e não sujeito como tão bem o irmão Procurador por que sendo assim [ILEGÍlVEL] para todo o tempo, e qualquer ora para o serviço da Irmandade e da mesma forma a Irmã a meza, escrivaã da meza.

Capítulo VI Da formalidade com que se ha de eleger a N. R. Capela. 
Querendo a Irmandade eleger capelão ordenamento Irmão andador. que participe a todos os Irmãos para na Santa Caza da Irmandade se não votar sobre os reverendos Irmãos sacerdotes que houverem na Irmandade qual ha de ser Capelão della procurando no numero deles o de mais santa vida com a perfeição de Pregador e Confessor prudente para exemplar e educar a Irmandade isto posto administrar se ha ao M. R. Parocha de cujo lugar para que com as suas senteça sobre tudo com acerto. Item quando por acazo haja de se espelir da Capelania a dito capelão, senão executará sem adjunto de toda a Irmandade ou parte della para perceberem a justa cauza que ouve de o espelirem, para que assim se despeça o dito reverendo capelão a paz e a salvo, e sem desdouro no carater de sua pessoa.

0254

Capítulo VII Da factura e obrigação do Irmão Andador, ou Zelador.

Para especificação dos negócios da Irmandade e a arrecadação das dívidas della, eh mui necessário eleger por voto hum irmãos isento de cativeiro que possa existir prontamente na porta do concistorio da parte de fora, todas as vezes quando formado para a condução de cartas, manda dos ou outros qualquer efeito que na mesa de determina e por seu trabalho sem e dará no fím do anno quatro mil reis, para que com melhor vontade e frequencia convoque aos Irmãos para os enterros. Acordãos da Mesa e tudo o mais que nella se oferecer a bem da Irmandade pois a tem da causa obrigatória deve de boa vontade a fim de obrar, para regime dos mais Irmãos qu diante preocuparem o sobredito cargo.

Capítulo VIII Dos Juizes que por sua devoção quizerem em festejar a nossa $\mathrm{Sr}^{\mathrm{a}}$.

Todo o irmão a qualquer qualidades ou outra qualquer pessoa não sendo do que quizerem por sua devoção, tanto homens como mulheres serem juizes e juizas de nossa Senhora nesta Santa Irmandade poderão ser quantos quizerem fazendo se de eles separada eleição para serem publicação podia da festividade da senhora pelo orador dela antes ou depois do dito cargo, tanto o juiz como a Juiza dará cada hum de esmolla quatro mil réis no fim do anno, para que com maior argumento, e presteza se continuem as obras da Santa Caza, e facturas de ornamentos para ella. 
Cap. IX

Da factura do Reye, Rainha de Congos e seus tributos

Todo Irmão ou Irmã da nação de Angola que por seus merecimentos a Irmandade eleger pra Rey, ou Rainha de nossa Senhora, se elegerão em pessoas vindas de cativeiro, só servirão a sujeitos não havendo libertos, ou forem esses insoficientes de ocuparem o dito cargo, porque destes incapacidade faz perder os meritos do dito cargo.

Serão obrigados tanto o Rey, como a Rainha a darem despendio cada hum anno quatro mil Réis, e serão os ditos obrigados a convencer as suas nações para compartilharem esmolas para as sobreas de nossa Senhora todas as vezes que pela Mesa determinar-se lhe as ditas esmolas. no fim do dia depois de tiradas, serão entregues ao Procurador da Irmandade. o qual será obrigado a passar recibo da quantia, que Receber a quem lhe entregar a dita esmolla para sua descarga. e o dito Procurador a se entregará em Mesa,ou ao Irmão Tezoureiro para as meter no cofre da Irmandade.

Cap. X

Das espórtulas dos Juizados, e os demais Cargos

A maior glória e o maior enterece que se pode procurar para o regime e argumento desta Santa Irmandade he que as pessoas que se elegerem para Juiz Mesa e mais mesa nos contenhão nelles os requizitos necessários para semelhantes cargos, dos quaes dará esmola o Juiz e Juíza da Mesa desse anno cada hum oito mil réis, a escrivão quatro mil réis cada hum. Mordomo, ou Mordoma dez tustoens, para que com estes deminutos preços possão servir com mais. Dezestenciais de suas pessoas na satisfação das ditas esmolas para argumento da Santa Caza da Virgem May de Deos, gosto e prazer de toda a Irmandade.

0256 


\section{Cap. XI}

Do dia da Festividade de nossa Irmandade

Na primeira oitava do Natal que se contão vinte e seis de Dezembro infalivelmente se celebrará a festividade de nossa Virgem Senhora do Rosário e para a qual será obrigada o Irmão Juiz actual consultar em Mesa hum mez antes do dias dos votos na festa que se há de fazer e determinada ella se fará, termo no livro delles e não havendo por alguma impssibilidade grande de obras da igreja ou outro qualquer effeito de circunstancia tao bem se fará termo no dito livro, porém havendo se fará público a toda Irmandade para que com essa noticia venhão assistir as vesperas, e dia da festividade da Senhora. Havendo procissão solene terá especial cuidade em se antecipar o Irmão escrivão em escrever as Cartas necessárias, logo que se determinar a Procissão. e as entregar o Irmão Zelador, ou Procurados para assim entregar aos Juizes daquellas Irmandades costumadas acompanhar sua Procisão, para que com o concurço de mais Irmãos fique mais esclarecida e favorável aos mesmos, e ainda daqueles que não são porque para esses as repetições de tal pio acto lhes introduz animo, ou vontade de procurarem a Santa Caza para della serem Irmãos.

Não havendo a dita Procissão por algum motivo sempre sairá no dia da festa a tarde o Santo Terço de nossa Senhora pelas rua publicas desta Vila com extraordinário acompanhamento de Irmãos que possível for: Ao revenrendo Parocho se dará de estipêndio da festa de nossa Senhora quanto he uzo, costume-se lhe dar, tanto no anno em que houver Procisão, como no anno, que não houver, não se inovando em tempo algum mais cressido por de minuto preço, porque sendo afim se cruza o dito Reverendo Capelão, de questionar com a Irmandade na sua parte.

0257

Cap. XII

Da existência dos Irmãos no dia da festa e recebimento das esmolas

Adverte-se que na véspera da festa de nossa senhora do Rosário virão todos Irmãos e irmãs assistir a ella como tão bem no seguinte dia da festa, com o melhor aceio que 
puderem para assistirem ao acto com todo o cilencio como tao bem separa no corpo da Igreja hua mesa com tinteiro e papel e principalmente o livro de entradas aos Irmãos para nelle ir abonando-se, os annaes dos Irmãos que nesse dia querem satisfazer e da mesma forma a mais esmollas que quizerem dar os Irmãos Juiz e Juiza e dos mais Officiaes da Mesa de seus Cargos, e juntamente as entradas dos novos Irmãos, e daquelles. que por sua devoção quizerem dar algua esmolla, e para recebimento dellas se acharão presentes o Irmãos Escrivão, e Tezoureiro, sem que para isso se escuzem para o sacristão prompto para tão grande beneficio, e serviço de nossa Senhora em argumento da Irmandade as sete horas do dia até o fim da celebração da festa e depois desta lançados que sejão os endimentos sobreditos, o dispendio que ouver lançará o Irmão Escrivão no livro da despesa.

Será aqui Escrivão especial cuidado nos lançamentos que fizer nos referidos livros fazendo com toda a clareza, esplicação abonando a cada hum, que pagar na folha do livro que lhe pertencer: fará tão bem hum roteiro do dito dinheiro que se recebeo em mesa para sua descarga, e ao Irmão os quaes com o Irmão Juiz o metera no cofre da Irmandade tendo este três chaves, que hua possuira o Irmãos Tezoureiro e com o dinheiro que nelle ouver separado todas as despezas que se fizerem preenciando a Mesa.

0258

Cap. XIII

Da dispozição da Missa na Coroação ao Rey d Congos

No dia da Coroação em que vem todos os Irmãos Juizes e Juizas e todos os mais Irmãos Reys e Rainhas a tomas suas varas e coroare,-se o procurados tirará por todos os que acharem prezentes capelão dez tostôes pela Missa e trabalho que há de Coroar os ditos e o que sobrar das Esmollas se dispendera-em guizamento para a sacristia e quando a esmola não chegue para o compito? da Missa a Irmandade completa e assim se assentou que senão desse esmola alguma mais os Reverendo do Capelão, se não os ditos dez tustões.

Cap. XIV 
Da factura da Eleição para os cargos dos Irmãos

Primeiramente se fará a Eleição dos Irmãos e Irmãs que hao dever vir anual em dia do Apóstolo S. Henrique he a vinte e dois de Dezembro, por ser o dias mais conviniente para o que seu juntara a Irmandade para se fazer a dita Eleição por que no dia da festa não se poderá fazer pelo trabalho, e perturbarção, que há da mesma festa e assim para este dia se mandará avizar a todos os Irmãos e juntos que sejão mandar se hua Missa ao Divino Espírito Santo dita pelo nosso Reverendo Padre capelão por tenção de todas os Irmãos da quem se lhe dará subindo para o Concistorio com elle a Mesa e o Irmão Escrivão com este Comprimiço presente, e o livros da Irmandade nelle escolhera o Juiz traz Irmãos suficientes para por votos ( aprovando a Mesa) se votarem nelles, e o que mais votos tiver será o Juiz.

0259

e não aprovando a Mesa nenhum dos eleitos por alguma circunstância será o Irmão Juiz obrigado a nomeando outros até serem três aprovados pela Mesa e o mesmo se entende com os facturas dos Irmãos escrivão. Procurador, Tezoureiro, Sacristão Zelador, Juiza, Escrivaa Mordomas, e Mordomos que serão doze da Mesa tanto Homens como mulheres.

Feita a dita Eleição [ILEGÍlVEL] [ILEGÍVEL] com Lacio ou Obrelha [sic] e cautela se há dentro do cofre e só delle se tirará no dia da festa de nossa Senhora para se publicar pelo orador della.

Tão bem se adverte que só assitirão na factura da dita eleição o Reverendo Capela o Sr. Juiz o Irmão Escrivão e os Irmãs da Mesa para na prezença destes se tomarem os votos com livre vontade de cada hum Irmão que votar e não assistirá fora dos nomeados Irmãos mais pessoas algua na tomadia dos referidos votos e o Reverendo Capelão dará o juramento de não revelar o segredo delles e tão bem mais adverte aos Irmãos que votarem, que o devem fazer com os olhos em Deos e no argumento da Santa Caza não votando constrangida de pessoa oposta ao bem da Irmandande.

\section{Cap XV}


Da obrigação do Juiz da Mesa Actual

Será obrigada o Irmão Juiz da Mesa a ver todos as vezes que for chamado para dar assistência da Mesa que ouverem naquela terá sempre o primeiro lugar, e da mesma maneira nas procissões e enterros, nos quaes prezidirá sempre com a vara na mão.

Item a nenhum tempo conservará em seo puder dinheiro algum da Irmandade porque só este pertence ao Irmão Procurador para delle fazer entrega Irmão Tezoureiro para que tão bem o ditto o destitua em Mesa perante os que nella se acharem e assim nada disporá. na Irmandade o ditto Irmão juiz sem concessão de toda a Mesa como tão bem nunca terá nella mais que hum unico voto.

0260

Cap. XVI

Da obrigação do Irmão Escrivão

O Irmão Escrivão fechará os livros e os mais papéis da Irmandade e nelles cumprirá com a sua obrigação nos assentos dos Irmãos que de novo entrarem, e lançar as contas que ouverem nos livros que lhes competir dando-as e tomando-as em prezença de de toda a Mesa a nenhum tempo poderá particularmente a isentar irmão algum sem que prezencie os demais da Mesa, e de cuja entrada fara termo no livro delles na conformidade e ordenação deste compromisso, e só fará entrega dos sobretidos livros no fim do anno de seo governo ao Escrivão sucessor que se eleeger, por que desta sorte se evitão as mas suspeitas e dellas se dezonera sobredido escrivão e conclue o seu anno sem nota nem defeito:

ultimamente segue-se o lugar do Juiz da Mesa, como segunda pessoa depois d Irmão Juiz.

\section{Cap. XVII}

Da obrigação do irmão Procurador

O irmão Procurador será obrigado todos os domingos e dias santos vir a esta Santa Casa indagar o que he necessário para o bem della e da falência que ouver 
partecipara ao Irmão Juiz e aos mais da mesa para a providencia de tudo e na falta do dito Juiz o mesmo Procurador dará a providência preciza e do mesmo modo obrará no falecimento dos Irmãos e tão bem tomará conta das esmolas que se tirarem pelas portas e das mais que se offerecer para as entregar todos os mezes em Mesa ao Irmão Juiz e mais Officiaes e da mesma forma tomara conta o dito Juiz a todas as Irmandades erectas na nossa Igreja no fim de casa hum anno, e o mesmo se entende nas facturas dellas, pois estão tributarias a nossa sempre esclarecida virgem do Rosário donna da Caza.

0261

\section{Cap. XVIII}

Da Da Factura do irmão Tezoureiro e sua obrigação

Procurar se há para Tezoureiro desta Santa Irmandade homem de san conciencia temente a Deos chao e abonado para que com as ditas condições fique a Irmandade satisfeita e bem servida e a Caza da May de deos em argumento. Será o dito Tezoureiro obrigado a acudir proptamente a Mesa que for chamado para nela receber o dinheiro que se lhe entregar para o a cautelar no cofre da Irmandade o qual terá três chaves possuindo hua o Irmão Juiz outra o Irmão escrivão, e outra o dito Irmão Tezoureiro na Irmandades e ella delle precize o dito tezoureiro abonará para lhe satisfazerem do primeiro que a Irmandade receber sem que para isso haja deficuldade alguma.

\section{Cap. XIX}

Das obrigações dos Irmãos da Mesa

Suposto que nesta Santa Irmandade haja hum Juiz da Mesa com seo escrivão para dispozições della, com tudo sempre haverá tão bem doze Mordomos da Mesa para que saiba o dito Juiz e Escrivão com elle bem consultar aquilo que for mais util e convincente ao serviço da May de deos e bem de Irmandade e assim serão obrigados a darem votos todos as occazioens que foi necessario em Mesa que aquella verdade e desencargo de huma boa conciencia sem afeição a couza alguma: tão bem 
acompanharao e assistirão a todos os enterros dos Irmãos não só os danos a sua Irmandade como tão bem aqueles que o não sendo por pobres e mizeraveis os sepulta a Irmandade pelo amor de Deos e de próximo pois além de devermos assim obter como fies catholicos, seremos recompensados do mesmo Deos.

0262

Cap. XX

Da obrigação do Irmão Sacristão

Por quanto o cargo de Sachristão he hum de que depende de a limpeza da Igreja de Deos nosso senhor e de sua Santissima May, o dito Sachristão cuidadozamente trata sempre em limpeza com o maior aceyo Altares e ornamentos delles e juntamente todas as Alfaias da Sacristia da Igreja. Será o dito obrigado a tocas sinos os dias das vespera e festas de nossa Senhora nas primeiros Domingos dos mezes e no falecimento dos nossos Irmãos te o tempo que se sepultarem pois para isso, e mais sufrágios dispenderão na nossa Santa Irmandade, e ultimamente tocará as vezes que e uso, e costume tocar-se principalmente empassando pela nossa igreja o senhora Santissimo Sacramento, do que nunca haja descuido. De nenhum modo entregará as chaves da Sacristia e Igreja a pessoa alguma que lhes peça, Salvo se achar-se enfermo, por que nesse cazo dará providencia ao exercicio de sua aquisição o Irmão Juiz com os mais da Mesa, a quem entregerão as ditas chaves querendo alguma ser tudo quanto tomou pois e para que a nenhum tempo hajão dúvidas, culpas, e desculpas de hua e outra parte no consumo disto ou daquilo dos bens da Irmandande que para recebimento delles se fará inventário para os bem receber e dar exata conta de tudo que por eles se lhe entregou findo que seja o seu ano. Mas se adverte, que em tomando posse da Sacristia o dito Sacristão se asignará ao pé do Inventário para que fique responsável a tudo que por seo descuido, fata de zelo e recato, se dezeincaminhar, salvo aos 2 atos de algum malevovo que com impiedade costumao por sagacidade de arrombos em cressida noite costumão saquiar as cazas alheias e profanarem os templos quando podem porque de conhecida a verdade desse insulto não ficará o sacristão responsável a satisfação. em remuneração de seo trabalho (além de hum tustão que lhe compete de cada sepultura) concordou toda a 
Irmandade se lhe desse quatro mil reis para cada anno e a Irmandade erecta de $\mathrm{S}$. Benedito e S. Antonio cada hua dez tustões e a do Senhor Jesus dos Martírios dous mil reias para mais trabalhoza.

0263

\section{Cap. XXI}

Da obrigação dos Irmãos em Geral

Todos os Irmãos e Irmãs geralmente sendo chamados as mesas que se lhes determinarem a condição a ellas prontamente para cumprirem o que se lhes ordenar do serviço de Deos e bem da Irmandade e quando não possão acudir por algum justo empredimento representarão ao Juiz e aos mais mezários os motivos de suas faltas e quando conste que não acudirão porque absolutamente não querendo que assim obrar será condenado pela primeira vez em meyo arratel de sera pela segunda hu arratel e pela terceira será admoestado em mesa sendo della disprezado por dezobediente e escandalozo aos mais Irmãos, e não havendo nelle emanda depois de admoestado segunda e terceira vez será riscado, porém se arrependido de seus erros procurar com humildade assim a Santa Caza pedindo perdão das suas faltas, e protestarão não ser nellas contumás, será outra vez admitido. salvo constando verdadeiramente ao Juiz de Mesa e mais Irmãos della ser o dito Irmão de sua nactureza pertubador da paz e solicitador de dezordens para inquietação da Irmandade, então nesse cazo nunca mais sera admitido.

Mais se declara que Irmão nenhum se entrometa Cargo daquelle que esta exercendo, porque quando este não execute bem a sua obrigação terá o refrigério de manisfestar ao irmão juiz para que perante elle e todos da Mesa seja repreendido o dito irmão do descuido de sua obrigação, para que com esse exemplo cumpra o modo como se lhe determina, e sendo recidente será [ILEGÍVEL] de primeiro, segunda, e terceira [ILEGÍVEL] benção se fará à Mesa e nela se elegerá outro irmão ao que ocupe o dito cargo ficando o Irmão delinquente que ao ocupava dezonerando delle como se nunca o ocupasse. 


\section{Cap. XXII}

Da determinação das sepulturas

Não poderá nenhum Irmão ter sepultura particular com letreiro sendo que não de por ella aquela quantia que lhe tributar o juiz e toda a Mesa que seja conveniente a Santa Caza de outra maneira se não iguaes para todos os Irmãos exceptuando as dos Irmãos seguintes

Nas primeiras covas abaixo do arco da Capela Mor só se enterrarão os Juizes, e ExJuizes, Juizas e Ex-Juizas no segundo andar das ditas sepulturas, os Escrivãos, e Exescrivãos, escrviaas e ex-escrivaas no terceiro andar, os procuradoes, exProcuradores no quarto andar os Irmãos da Mesa, destes se entende falecendo no anno em que servirem, que fora delle serão sepultados na Sacristia. Qualquer das mulheres dos ditos Irmãos acima, em seo falecimento gozará o mesmo predicado de seo marido, que dejuz se lhe deve do cargo que o ocupou e da mesma forma que a elles refere executará em suas mulheres conforme o cargo de cada hum dos do mesmo predicado se não distingue o filho de matrimônio de menoridade dos ditos Irmãos e Irmaas, pais todos elles tantos mulheres, como filhos matrimoniados, gozão esse beneficio pelo [ILEGÍVEL] mesmo modo que se obrar no enterramento do dito Irmão Juiz tao bem se obrará com os Irmãos reconhecidos por bem feitores, que dispendendo seo dinheiro na Santa Caza tanto elle como sua mulher e filha de matrimonio.

Querendo qualquer pessoa sem separação de qualidade em terreno em sepultura da Capela Mor se fará junta de todos os Irmãos com assistencia do Reverendo Parocho e Capelão da Irmandade e se manifestara ao Excellentissimo e reverendissimo Senhor Bispo e o que o dito Senhor dispuzer se fará e intentando outra pessoa não sendo Irmão enterrar-se das grades para dentro, se não concederá sem junta da Mesa para lhe comutar o preço que for licito dar se pela sepultura e sendo das grade para fora dará de esmolla dous mil réis e de menino dex tustoens.

0265

Cap. Das Missas ditas na nossa Igreja pelo nosso R. Capelão 
Para maior utilidade e bem das almas assim dos Irmãos vivos como defuntos da nossa Santa Irmandade se mandam dizer pelo nosso Reverendo Padre Capelão duas capelas de Missas hua todos os Domingos pelos nossos Irmãos vivos, e outra nos dias santos pelos Irmãos defuntos, todas ditas na Capela Mor da nossa Igreja e a elas assistirao dous Irmãos compostos com suas Opas e toches acezas, e mais outro Irmão com a Cruz da Irmandade.

\section{Cap. XXIV}

\section{Da Missa de Quinta-Feira Maior}

No anno em que se expuzer o senhor santissimo sacramento no dia de quinta feira Maior se mandará tirar trovisão antecipadamente do Excellentissimo e Reverendissimo Senhor Bispo aprezentando se esta ao reverendo parocho para conceder licença a se puder comprimentar com o santo sepulcro no referido dia e se lhe dará de esmola dela Missa dous mil reis, e pelo trabalho de expor e encerrar o senhor nesse tão grande dia como nos mais que se expuzer em festas de nossa Senhora e não se dará a sacerdote algum vindo este em lugar do parocho mais que os ditos dous mil reis e aos sacerdotes que assistirem se confessarem Irmãos, três patacas e não confessando suas patacas não mais.

0266

\section{Cap. XXV}

Da disposição da tumba para carreto de Nosso Irmãos

Pareceu ato da Irmandade por bem que a tumba em que se carregao os Irmão de nossa senhora do Rosário, se não carregase outra pessoa alguma que não fosse Irmãos ainda que desse avantejada esmolla por ella, porque essa só regalia queremeltes para aquelles seus Irmãos e Irmaas que gastavao o seo dinheiro em obsequio e serviço da Virgem May de Deos, e que somente ouvesse hum esquife com seo panno para aquelles que não fosse de que dariao de esmolla sette mil réis para a Irmandade indo esta com o seo Guiao e Cruz e querendo alguma pessoa que 
em seo falecimento o acompanhe o dito Guião, e Cruz para outra Igreja darão de esmolla dous mil réis.

\section{Cap. XXVI}

Da visitação aos Irmãos quando estiverem enfermos.

Por quanto huma das obras de misericórdia he vizitar os enfermos ordenamos que quando algum Irmão desta Irmandade estiver doente os que primeiro souberem o hira vizitar e lembrar-lhe que se confesse, e comunique, e farao saber aos Irmãos da Mesa os quaes se informarao com todo cuidado se esta empobreza e sendo certo cada hum dos Irmãos da Mesa tirara esmollas pelas portas, e depois convocarão a Irmandade afim Irmãos, como Irmaas para que todos juntos em prezença do Reverendo Capelão se tire por todos huma esmolla dando cada hum o que puder para alimento, e curativo do dito Irmão pobre, que sempre por qualquer via se deve socorrer para que não morra ao dezamparo, e neste particular se não há de faltar com a Caridade, isto hé

0267

sendo o irmão forro que sendo cativo o deve fazer seo senhor, salvo se for senhorio mui pobre que de nenhua sorte o possa curar do que investigarão [mente] de pessoas dignas decredita, que reconheça a pobreza do Senhor do dito Irmão. Tão bem se adverte estando algum Irmão prezo os Irmãos da mesa deligenciarao com suas pessoas ao seo livramento como tao bem os mais Irmão em tratar com a maior brevidade na Soltura dele não sendo a prizão por alguma infamia que sirva de deshonra a si e a Irmandade porque nesse cazo fica dezonerado deste beneficio insoficiente de ser nosso Irmão na referida Irmandade.

\section{Cap. XXVI}

Das cauzas por onde se que qualquer Ir. da Irmandade

Primeiramente todo o Irmão que não pagar a esmolla da conhecença pedindo se lhe, e tendo posse para pagar nao o fazendo será riscado da Irmandade. 
Em segundo lugar sendo chamado a Santa Caza da Irmandade para as consultas della e o mais que for do serviço de deos nosso senhor para a salvação de nossas almas.

Item não aceitando os cargos da Irmandade que por eleição sair a primeira vez ou a ceittindo os descobrir o segredo que se expuzer em mesa.

Item: não sendo zeloso no serviço da Igreja, defensor della e de toda Irmandade induzindo os Irmãos para nas Eleições votarem em seus parciaes amigos, deixando o que for

0268

ilícito bem da Irmandade sendo acordo della, dias para condição --- querendo só conseguir o seu intento com a pozição contrária a tudo aquillo que for útil para o augmento desta Irmandade.

Item não respeitando ao Juiz, e mais officiais da Meza disfraudando os e vivendo escandalozamente sem temor de Deos e do mundo dando se a vicios que lhe sirva de discredito, ou sendo castigado em Juizo por cruel delito.

Item sendo que sirva em algum Cargo não querendo dar contas quando o findalizar sendo chamado ara ellas ou dando as com equivocos sem clareza e verdade que requer em ditas contas.

Em todas estas condições ou clauzulas referidas precederá sempre o serem tres vezes admoestados pelo Juiz, e mais Irmãos da Meza, cazo se cauza for de tal sorte que seja disnecessário admoestação se não com o parecer dos da Meza serem despedidos logo e para esse efeito não necessitar se há demais junta que do Juiz e mais Oficiais daquele anno a servirem mas todo o Irmãos que for riscado da Irmandade e couber no possivel ser outra vez vez admitido poderá depois pedir por petição com aquela devida humildade que outra vez hajão de admititr e neste ponto seguirá o que dito fica, pois não he nossa tenção nem vontade riscar por huma vez dos nossos irmãos se não depois de não emendados, e arrependidos da culpa cometida. 


\section{Cap XXVIII}

Da providência dos Irmãos quando inimizados

Tanto que algum Irmão souber que entre ellees há algumas inimizades manifestara logo ao nosso Reverendo Capelão para que os mande chamar em Mesa perante o Juiz e mais Irmãos della a faze-los continuar na amizade que dantes tinhao, vivendo em boa união sem cauza de mormuração aos mais Irmãos, attendendo que das inimizades se originão muito males, e são essas fora do agrado de deos: não obedecendo o dito Irmão ao chamado para a dita união será obrigado o nosso Reverendo Capelão penitencia lo como meresser e não cumprindo a emposta penitencia sera expulso da Irmandade.

\section{Cap XXIX}

Da disposição dos bens da Irmandade

Todas as vezes quizer vender alguns bens de Raizes que a Irmandade tenha ou se lhe de algua dadiva com alguma penção se avizará a todos os Irmãos que se acharem no lugar e ao Reverendo Vigario para com o Reverendo Capelão e todos da Mesa, consultarem com acerto, o tributo da dita penção, e nunca se fará negocio algum nem obra na Igreja sem junta de toda Irmandade para que com o parecer de todos se execute em modos que fiquem contentes e satisfeittos e para factura da obra ou outra couza não se dispenderá dinheiro nenhum sem vista de parte dos Irmãos a verem em que se distribue para que assim se izentem do reparo do gasto delle e sirvão, com mais vontade na Irmandade.

0270

\section{Cap. XXX}

Para senão dar dinheiro a juros nem por empréstimo

Nunca se dará dinehiro a juros por enquanto não falta em que se dispender tanto em obras como em ornamentos, e kfacas da Igreja, sem em extrema necessidade precizando algum Irmão ou Irmaa de bom procedimento e boa vida para a sua 
liberdade se lhe dará ( havendo) sobre pinhores de ouro, e prata que demais algua couza cubra a dita quantia ou dando fiador chao,e abonado, e dezembarassado de algum sequestro que por elle seja dificultoso a cobrança do dinheiro, o qual não passará do tempo de dous annos, alis se venderão os pinhores, ou obrigar se há ao dito fiado, como se declarará por papel do trato que se passar data do dinheiro, que se lhe der para a dita liberdade.

\section{Cap. XXXI}

Das cauzas Judiciaes que ouverem na Irmandade.

Havendo na Irmandade algumas demandas ou Requerimentos em Juio, o Juiz e mais Irmaos da Mesa actual elegera hum letrado para defença della e aconcelhar ser ou não ser justo os e continuarem por falta de direito, exponde todo o sucedido Realmente ao dito letrado para o arrazoado dellas e em todo o cazo se deligenciara por as não haver e tao bem não podendo deixar se de seuilas por sendo querer acomodar de aparte contraria nesse cazo, por a todo o cuidado o Juiz, com mais mesanos, sem que haja o minimo descuido por donde saya a revelia, ou contra a Irmandade, o que sera mui prejudicial.

0271

\section{Cap. XXXII}

Do regime das esmolas que hão de tirar o Juiz, e toda Mesa.

Para maior augmento da Igreja, Serviço da Mae de Deos e exemplo de toda a Irmandade será obrigado o Juiz da Mesa no primeiro mez de seo governo com o Irmao Escrivao atirarem esmolas pelas portas de todos os fieis de Deos, e asssim continuarao os Irmãos da Mesa de dous em dous por suas antiguidades, para o que se por a delles hum roteiro na Sacristia a as esmollas q tirarem as entregarao ao Procurador havendo delle recibo de descarga, codito Procurador dará conta dellas e das mais q ouver recebido em Mesa no fim de cada mez não ostendo-as em sua mão por algua negociação de conveniencia sua com prejuizo da Irmandade com esmo 
observará os esmoleres referidos e todos os demais Irmãos, q em sua mão parar dinheiro da Irmandade.

\section{Cap. XXXIII}

De alguma pessoa que por sua devoção queira festejar a sua custa

Avendo pessoa alguã de qualquer condição que seja querendo servir de Juiz de nossa Senhora do Rosário, ou de algum dos mais Santos erectos na nossa Santa Caza festejando dezenteressadamente a sua custa, cujo beneficio lhe agradecera muito a Irmandade, e havendo Procissão, nella nunca levará as insignias sendo os nossos Irmãos pretos e somente se concede do Juiz actual e os da Mesa obsequiarao de voto. Juiz entregando lhe a vara de prata para com ellas prezidir atras do Pálio em remuneração do que asima dito fica.

0272

\section{Cap. XXXIV}

Dos Jubileus concedidos a esta Irmandade

Num dia de domingo de Dezembro há Julibeo nesta Santa Irmandade como tao bem em todas as festas de nossa Senhora e para que haja lembrança de tão grande beneficio o nosso Irmão sacristão terá especial cuidado nos taes dias e vesperas de tarde e a noite. Repicar os sinos para suavizar a todos os Irmãos a se confessarem e comungarem nesta Santa Igeja e em outra qualquer que se lhe oferecer, e para ajuda das ditas confissoens se achará prontamente o nosso Reverendo Capelao para cumprir com asua obrigação de confessar os Irmãos que puder, a participarem das Indulgencias dos Confrades do Rosário da Senhora.

\section{Cap. XXXV}

Do Officio aniversário, pelos Irmãos defuntos

Será obrigado a Irmandade a mandar fazer todos os annos hu officio por todos os Irmãos defuntos depois da festividade de nossa Senhora em dias do mez de novembro no oitavario da comemoração dos defuntos, para o qual a Mesa actual 
andará avizar todos os Irmãos, e Irmaas para que infalivelmente venhão encomendar as almas dos ditos Irmãos falecidos que por divina Ley somos obrigados para ----das penas purgativas e salvação das suas almas.

0273

\section{Cap. XXXVI}

Sobre os particulares da Mesa a que se faça termo delles

Para que tudo se cobre com acerto e perfeição em todos os negocios da Irmandade em em Mesa e consultarem logo o escrivão da Mesa ou outro Irmão a quem o dito der concessão fará termo no livreo delles em que toda a Mesa se asignará para em todo o tempo constar que tudo o que se abra em Mesa hé sem equicação ou dollo e para anenhum tempo se puderem desdizer que o que se obra não foi com o parecer da dita mesa, e não se fará esta nem adjuntada algum sem asistencia do Reverendo Capelão e os negocos que foram de segrego, o dito dará juramento para que os não descubra.

\section{Cap. XXXVII}

Da prezença do comprimiço em Mesa sendo precizo

Todas as vezes que fizerem Mesa terão prezentes este comprimiço para que havendo algumas duvidas p. elle as disfação, sobre qualquer materia que se offeresser o que individuarão nos capitulos que nesse se conthem, e o mesmo observarao nas facturas das eleições e todos os particulares da Mesa, pois delle consta o encaminhado de todas as couzas para o bom governo da nossa Santa Irmandade.

0274

\section{Cap. XXXVIII}

Dos livros que haverão na Irmandade

Para bom Regimen desta Santa Irmandade havera nella dez livros o primeiro livro mestre para constar dos assentos ou entradas geralmente de toda a Irmandade lançando o nome de casa hum Irmão pela letra que lhe compete no ABCdário do 
dito livro. O segundo e terceiro será hum para a Receita e outro para a dispeza lançando-se nelles tudo pelo meudo eligivel. O quatro para as facturas das Eleições. O quanto para os Termos ou Acordaos que se fizerem. O sexto para lançamentos de alugueres de Cazas. O sétimos para as escripturas ou doações da Irmandade. Oitavo para as sepulturas dos Irmãos defuntos para governo de suas Missas. O nono para as certidoens das ditas Missas apotecadas por todos os Irmãos defuntos, e dessimo para lançamento daquelllas esmollas e parte que derem os Irmãos Benfeitores.

Todos estes livros trara o Irmão Escrivão acautelados com especial cuidado não sahindo a nenhum tempo fora do arquivo da Irmandade livro algum mais que tao somente o dos annaes nas occazioens em que forem a cobrança deltes, como tão bem o da Receita e dispeza quando delles seder as contas em Juizo a ficarem aprovadas pelo Ministro, e fora do expressado só poderão aparecer qualquer dos sobreditos livros em Mesa quando nessa se preciza para que com este recato se evite algum descaminho q delles pode haver e valer-se o Irmão escrivão da disculpa da ignorancia e confiso seizente? Ficando a Irmandade prejudicada na falencia delles e sendo assim suceda ficará o escrivão responçavel ao danno que nessa parte ouver.

0275

\section{Cap. XXIX}

Da forma e maneira q seção de reger nas Procissões e Enterroz

Todas as vezes que ouver de sair a Irmandade formada a qualquer acto de procissão ou enterros se observa na forma seguinte. Primeiramente no dito acto de Procissão seguirá a Cruz da Irmandade acompanhada de dous Cirios de hum e outro lado e logo atras seguira a Irmandade do Senhor Jesus dos Martírios por ser esta a mais moderna Irmandade entre as que, se achão erectas na nossa Santa Caza seguindo com a sua Cruz Cirios e os Irmãos della formados em duas alas tantas da parte direita com outros tantos da parte esquerda cubrindo o seu Provedor e Capelão: da mesma forma continuará atraz da dita Irmandade de Santo Antônio da Catagerona cubrindo o seu Juiz e Reverendo Capelão e em terceiro lugar seguirá a Irmandade de São Benedicto na mesma formalidade das outras assim ditas e finalmente seguirá a 
nossa Santa Irmandade de nossa Senhora do Rosário como Senhora e Mai da Caza e depois do seguimento dos Irmãos que nunca ocuparão cargos exercerá aquelles que já icuparao e seguintemente a Mesa do anno actual sendo o último da fileira da parte direita o Irmão Escrivão e da esquerda o Irmão Procurador e com separação de tudo fecharáo acto no dim das sobreditas fileiras em meio dellas o nosso Reverendo Capelão da parte direita e o Irmão Juiz da parte esquerda.

O mesmo se executará na sociazioens de de enterros, quando os defuntos sejão Irmãos de todas as Irmandades referidas puxando adiante de todas o nossos Guião e no fim dos das filiaes seguirá a Cruz e Cirioes

0276

da nossa Irmandade concluindo o acto no modo que replicadas vezes dito fica tão bem se adverte que a festividade do Senhor dos Martírios se fará infalivelmente a três de Maio dia da Invenção da Santa Cruz como de costume. A de Santo Antonio de Catagerona na primeira oitava do Divino Espirito Santo e a de São Benedicto na primeira oitava da Paschoa.

Item querendo Algum Irmão branco por seo falecimento que o seo corpo seja conduzido na Tumba da nossa Irmandade não haverá dúvida alguma se não em não se conduzido por Irmãos de superiores cor sim será pelos nossos Irmãos pretos conduzido.

Cap. XL

Das constituições e estatuto deste compromiço

E por quanto os estatutos, contituiçoens deste compromiço formados para a regularidade desta devota confraria estabelecida acento e sacristia e tantos annos por não serem confirmados pelo prícipe soberano se não tem observado com a devida inteireza para o pretendido fim dos exercicios spirituaes augmento das virtudes, honra, e gloria de Deos e de Maria Santissima, Padroeira da mesma. Confraria por unanime resolução do Juiz Escrivão e mais Mesanos em nome de todo o corpo mistico da dita confraria, se poem na Real prezença de Sua Magestade Fidellissima, 
as prezentes Constituições e compromiço e a dita Senhora se joga, e emplora com toda a humildade devida q como suprema legisladoura se sirva com

0277

Confirma-lo para que com sua Regia Authoridade [ILEGÍlVEL] exacta observancia, e se evite qualquer duvida e senistra interpretação de alguns Irmãos imprudentes, pois que todos se comprometem a cumprir e guardar com toda a enteireza o que no dito Compromiço se tem estabelecido regulamento por ele regulado não se apresenta e se promete a asignar mais tão bem todos os futuros que alguém de unir-se ao corpo místico da mesma confraria como seja já o de não haver na Caza Irmandade algua previlegiada sem subjeção a mesma e menos coartar e sim geral para todo genero de Nação por ser licito que todos possão participar do beneficio espiritual de cada hua dellas não passando pelo descanso da izenção tão opposto de razão christaa.

\section{SENHORA}

Os pretos da Vila de Goyanna do Recife de Pernambuco humildes e fiés vassalos de Vossa Magestade para melhor praticarem as virtudes christaes e conceguirem a suma e eterna felicidade estabelecerao uma pia corporação da confraria do soberano Rosário de Maria Santissima, a cento, e secenta e tantos annos construindo e um? Templo a mesma Senhora tua padroeira, e persuadido de que não pode haver sociedade sem que hajão leys que as regulem: elles juntos se ao prometerão e fizerão os prezentes estatutoz e constituições nos quaes escreveram os estabelecimentos uteis a conservação

0278

de de sua confraria, e porque para --- serem enteira observancia lhes hé necessario a autthoridade legislativa, que só subsiste nas sagradas pessoas dos Principe, humildes e reverentes chegao aos reaes péz de Nossa Magestade e em nome da nossa Senhora --- a sua Magestade ---- confirmar aqueles estatutos, constituições que com todo o respeito e acatamento se offerecem a real prezença de Vossa Magestade e mandando pela tua régia authoridade que se observem como nelles se conthem. ERM 